\title{
Mapping the Glacial Geology of the Central Great Lakes Region in Three Dimensions- A Model for State-Federal Cooperation
}

\section{U.S. GEOLOGICAL SURVEY OPEN-FILE REPORT 99-349}

Prepared in cooperation with the Illinois State Geological Survey Indiana Geological Survey Michigan Geological Survey Division Ohio Division of Geological Survey

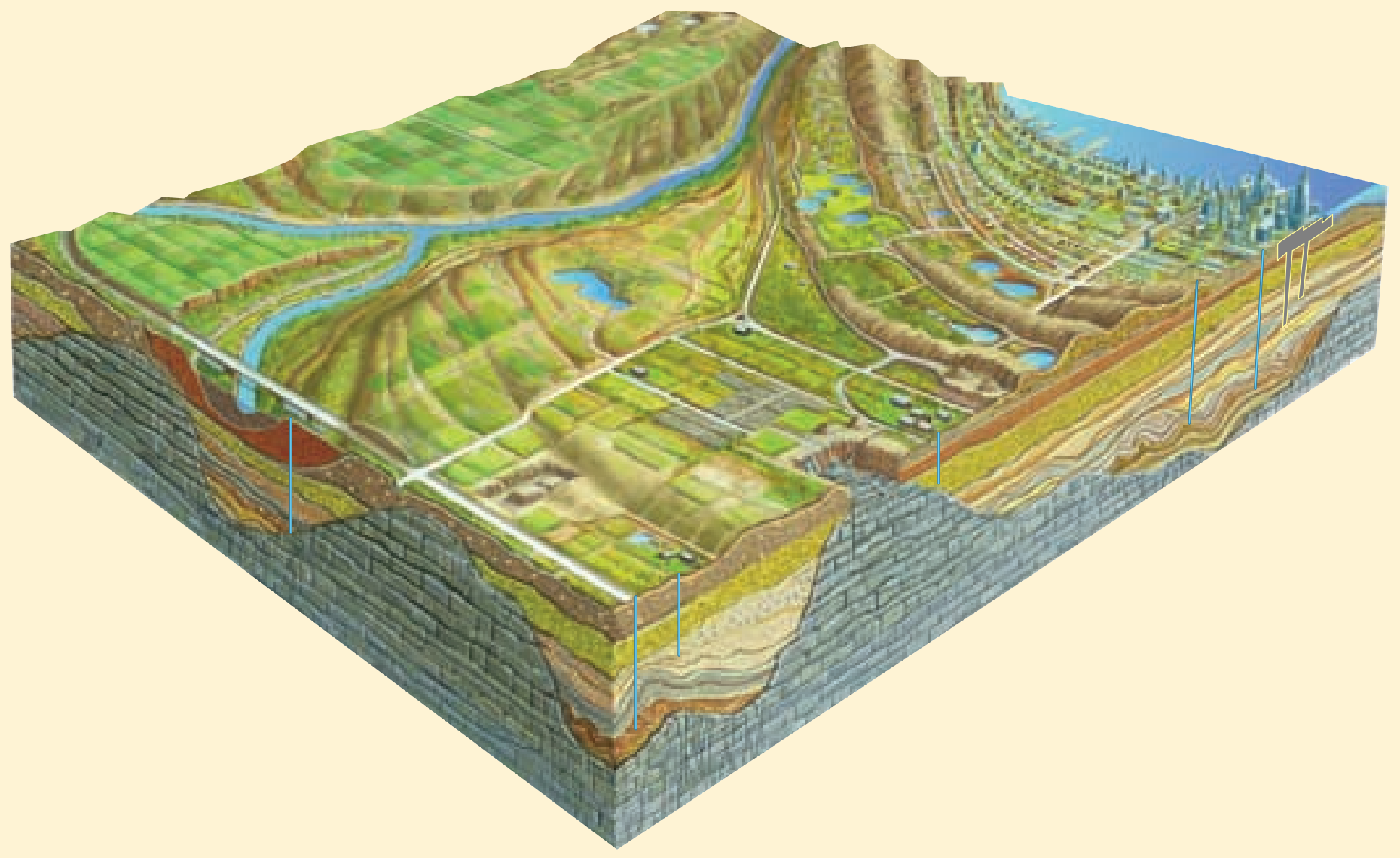


Cover. This block diagram is a generalized representation of surface land uses and underlying deposits in Illinois, Indiana, Michigan, and Ohio. The relatively flat farmland plains and rolling hills conceal a complex mix of glacial deposits stacked above ancient rocky hills and valleys like a pile of rumpled patchwork quilts. During the last 1.8 million years, each glacial advance and retreat modified the previous landscape and deposited new layers of clay, silt, sand, gravel, and till, capped by soil. The thickness of the glacial deposits ranges from a few inches to more than 1,300 feet. Diagram by J.M. Evans, USGS. For additional information on the relations between glacial features and modern land uses and for a depiction of the water table, see a modification of this diagram in the yellow pages, Article 2, Water Resources. 


\title{
Mapping the Glacial Geology of the Central Great Lakes Region in Three Dimensions- A Model for State-Federal Cooperation
}

\author{
By Richard C. Berg, Illinois State Geological Survey \\ Ned K. Bleuer, Indiana Geological Survey \\ Berwyn E. Jones, U.S. Geological Survey \\ Kevin A. Kincare, Michigan Geological Survey Division \\ Richard R. Pavey, Ohio Division of Geological Survey \\ Byron D. Stone, U.S. Geological Survey
}

\section{U.S. GEOLOGICAL SURVEY OPEN-FILE REPORT 99-349}

Prepared in cooperation with the Illinois State Geological Survey

Indiana Geological Survey

Michigan Geological Survey Division

Ohio Division of Geological Survey

Under the National Cooperative Geologic Mapping Program, four State surveys and the U.S. Geological Survey are collaborating in the research and delivery of geologic information to support critical societal decisions about land and water resources, the environment, and geologic hazards. 


\section{U.S. DEPARTMENT OF THE INTERIOR BRUCE BABBITT, Secretary}

\section{U.S. GEOLOGICAL SURVEY \\ CHARLES G. GROAT, Director}

Printed in April 2000.

Manuscript approved for release July 16, 1999.

Any use of trade, product, or firm names in this publication is for descriptive purposes only and does not imply endorsement by the U.S. Government or State governments.

Copies of this report are for sale by:

U.S. Geological Survey

Information Services

Box 25286, Federal Center

Denver, CO 80225

or call the toll-free telephone number

1-888-ASK-USGS

For more information, contact:

Chief Scientist

Eastern Earth Surface Processes Team

U.S. Geological Survey

National Center, MS 926A

Reston, VA 20192

Program Coordinator

National Cooperative Geologic

Mapping Program

U.S. Geological Survey

National Center, MS 908

Reston, VA 20192

State Geologist and Chief

Illinois State Geological Survey

615 East Peabody Drive

Champaign, IL 61820

State Geologist and Director

Indiana Geological Survey

611 N. Walnut Grove Ave.

Bloomington, IN 47405

State Geologist and Chief

Michigan Geological Survey Division

P.O. Box 30256

Lansing, MI 48909

State Geologist and Chief

Ohio Division of Geological Survey

4384 Fountain Square Drive

Columbus, $\mathrm{OH} 43224$ 


\section{CONTENTS}

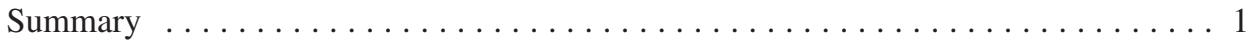

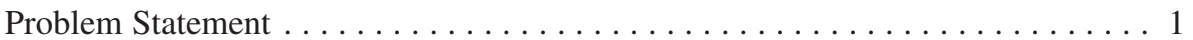

Central Great Lakes Geologic Mapping Coalition-Addressing Geologic

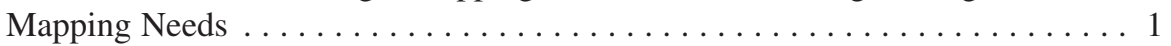

Three-Year Pilot-Study Phase and the Fourteen-Year Intensive Mapping Phase. . . 2

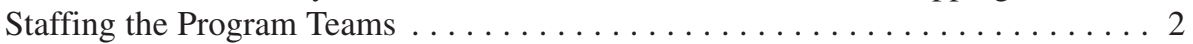

Costs of the Program. . . . . . . . . . . . . . . . . . . . 3

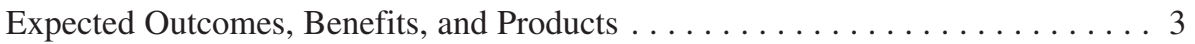

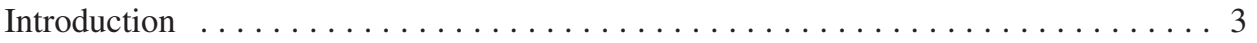

The Central Great Lakes Geologic Mapping Coalition and its Mission ....... 5

Goals of the Program .............................. 6

Purpose and Scope of this Report ....................... 6

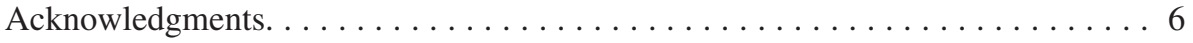

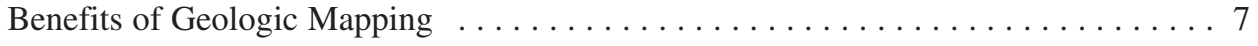

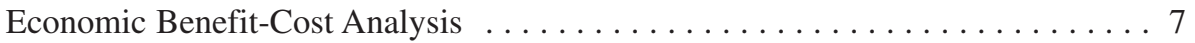

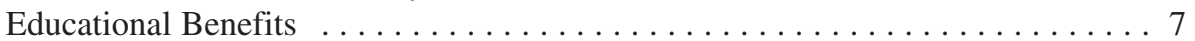

Public Education ............................. 7

Professional Education .......................... 7

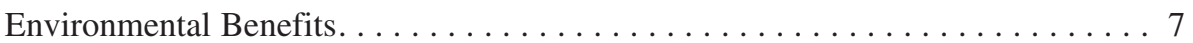

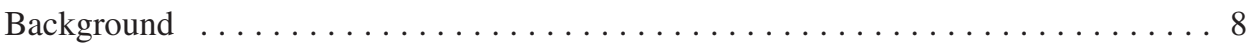

Surficial Geology and Issues for Sustainable Development $\ldots \ldots \ldots \ldots \ldots 8$

Surficial Geology of the Central Great Lakes Region . . . . . . . . . . . . . 9

Surficial Geologic Maps and New and Emerging Technologies........... . 9

Three-Dimensional Maps, Models, and Analyses . . . . . . . . . . . . . 11

New Geologic Maps Supported by Digital Data Bases ................ 12

Glacial Terrane Characterization, Vertical Sequences, and Morphosequences . . . 16

Surficial Geologic Materials Units . . . . . . . . . . . . . . . . . 16

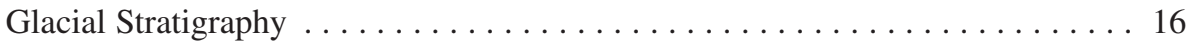

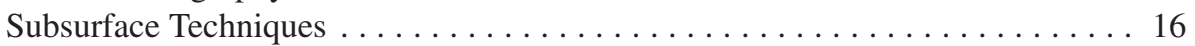

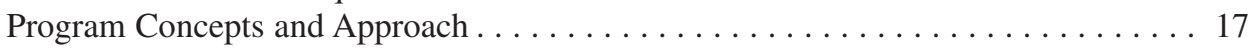

Local Issues . . . . . . . . . . . . . . . . . . . . . . . . . . . . 17

Existing Data . . . . . . . . . . . . . . . . . . . 17

State and Federal Data Bases and a Geologic Information Delivery System . . . 18

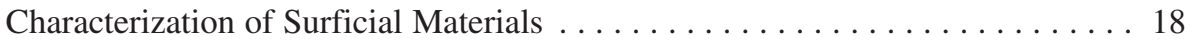

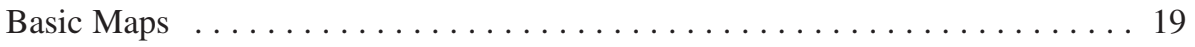

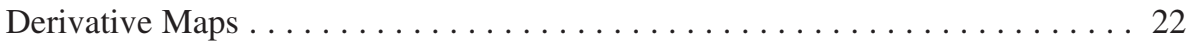

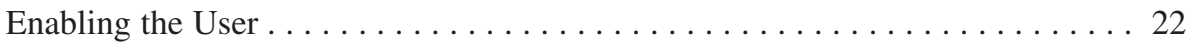

Education and Outreach ........................... 23

Continuous Reassessment of Mapping Priorities $\ldots \ldots \ldots \ldots \ldots \ldots \ldots 23$

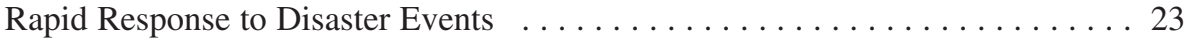

Strategy—Design of the Program .......................... 24

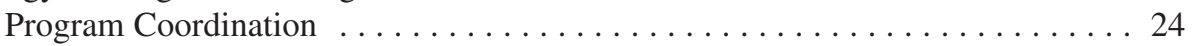

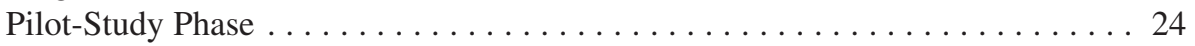

Project Planning, Protocols, Training, and Preparation: Year $1 \ldots \ldots \ldots 24$

Pilot-Study Phase Mapping Projects: Year 2, Year $3 \ldots \ldots \ldots 25$

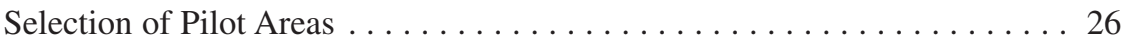

Development of Systematic Study Approach . . . . . . . . . . . . . . . 29 
Strategy_Design of the Program-Continued

Intensive Geologic Mapping Phase: Year 4 Through Year $17 \ldots \ldots \ldots$. . . . 30

Prioritization of Mapping .................... 30

General Approach and Project Schedule . . . . . . . . . . . . . . 30

Regional Maps and Analysis: Year 4 Through Year $17 \ldots \ldots \ldots$. . . . . 30

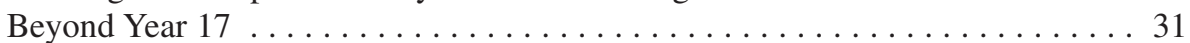

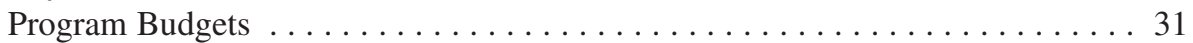

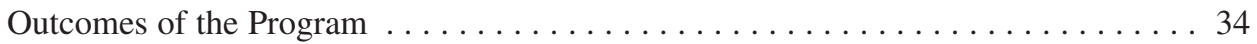

Geologic Information for the Central Great Lakes States. . . . . . . . . . . . . . 34

Enhancing the Public Service Mission of the Geological Surveys . . . . . . . . . 36

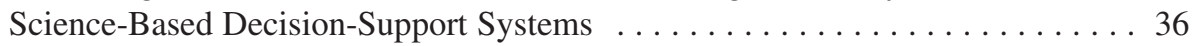

Education of Surficial Geologists Results in Increased Information and its

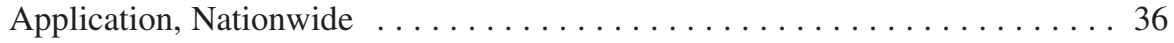

Public Awareness of Earth Science Issues in Public Policy . . . . . . . . . . . . 36

Improving Communication Between Earth Scientists and Public Policymakers . 36

Extension of Cooperative Surficial Geologic Mapping Programs to Other

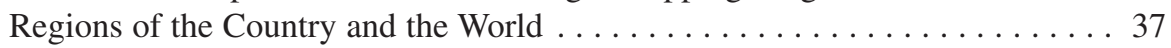

References............................. 37

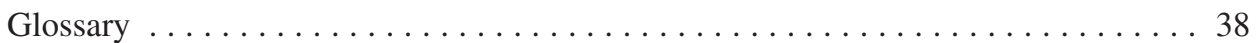

\title{
REGIONAL SOCIETAL ISSUES REQUIRING EARTH SCIENCE INFORMATION
}

\author{
[Unnumbered yellow pages in the center of the report \\ contain nine short articles]
}

1. Competition for the Land

2. Water Resources

3. Construction Materials

4. Coastal Erosion

5. Floods

6. Earthquakes

7. Contamination of Land and Water

8. Ecosystem Change

9. Education as Part of the Program 


\section{FIGURES}

1. Map showing proposed prioritized study areas in the Central Great Lakes States $\ldots \ldots \ldots \ldots \ldots \ldots \ldots . . \ldots$

2. Maps showing location of the four Central Great Lakes States and location of population centers

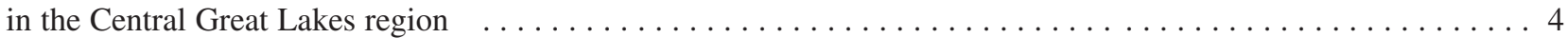

3. Photographs showing urban land and agricultural land in the Central Great Lakes States $\ldots \ldots \ldots \ldots \ldots \ldots$

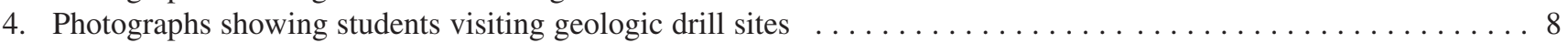

5. Maps showing glacial and related deposits of the Central Great Lakes States $\ldots \ldots \ldots \ldots \ldots \ldots \ldots \ldots \ldots . \ldots 9$

6. Photographs showing examples of surficial geologic materials $\ldots \ldots \ldots \ldots \ldots \ldots \ldots \ldots \ldots \ldots \ldots \ldots$

7. Geophysical record (natural gamma radiation of deposits) from the Marion Valley, east-central Indiana . . . . . . 11

8. Photograph of an Illinois quarry showing layered glacial and interglacial sediments overlying bedrock . . . . . 11

9. Map showing areas in the Central Great Lakes States depicted on traditional surficial geologic maps

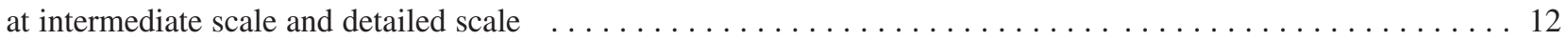

10. Map showing areas in the Central Great Lakes States depicted on three-dimensional maps, including

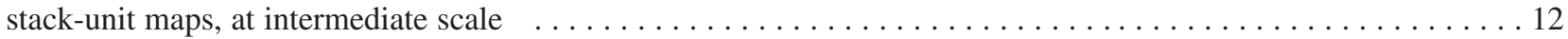

11. Interpretive cross section showing late Wisconsinan- and Illinoian-age glacial-lake deltaic deposits $\ldots \ldots \ldots \ldots 13$

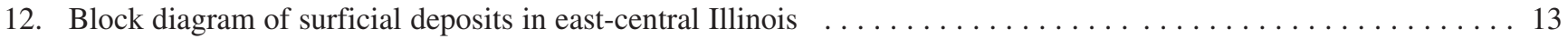

13. Fence diagram composed of nine cross sections through the surficial deposits and upper bedrock

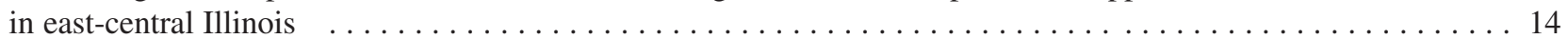

14. Block diagram showing surface-elevation map of the Mahomet Sand aquifer $\ldots \ldots \ldots \ldots \ldots \ldots \ldots \ldots$

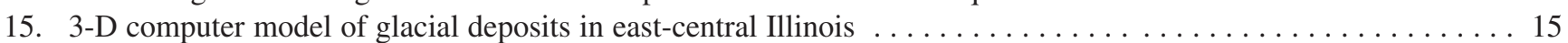

16. Map showing concentrations of uranium associated with surface materials of northwestern Ohio $\ldots \ldots \ldots \ldots 17$

17. Flowchart showing the process of making surficial geologic maps $\ldots \ldots \ldots \ldots \ldots \ldots \ldots \ldots \ldots \ldots \ldots$

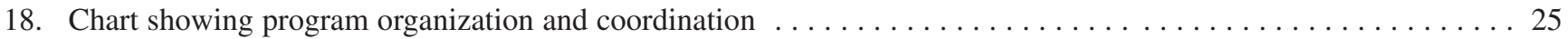

19. Map showing proposed mapping areas of the pilot-study phase of the Central Great Lakes Geologic

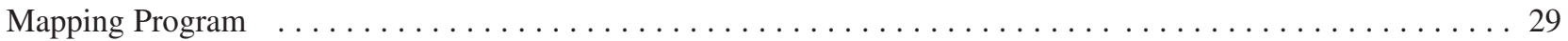

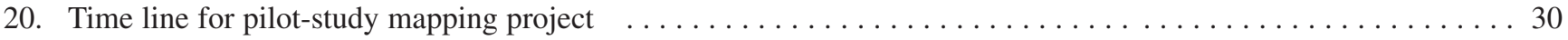

21. Map showing proposed mapping areas for the intensive mapping phase of the Central Great Lakes

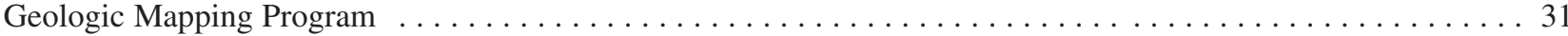

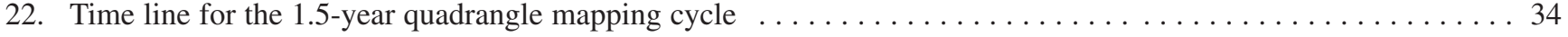

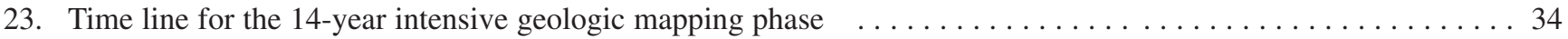

\section{TABLES}

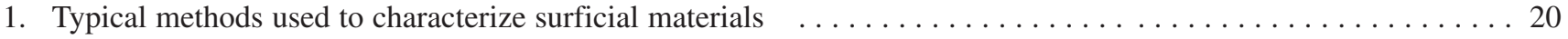

2. Basic geologic maps and map products to be produced by the Central Great Lakes Geologic

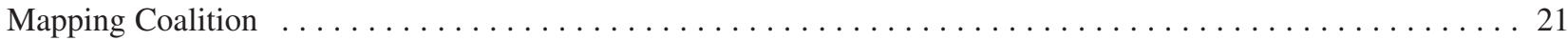

3. Possible derivative maps and potential applications based on geologic mapping and related earth science data . . . 22

4. In-house capabilities and needs for field sampling and description, laboratory analysis, and mapping support . . . 26

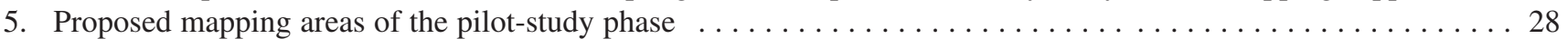

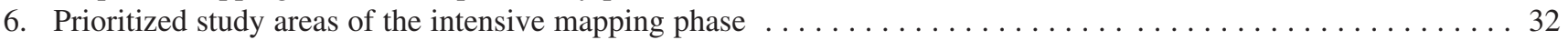

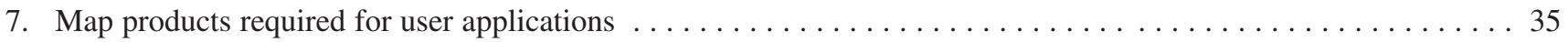




\title{
Mapping the Glacial Geology of the Central Great Lakes Region in Three Dimensions- A Model for State-Federal Cooperation
}

\author{
By Richard C. Berg, Ned K. Bleuer, Berwyn E. Jones, Kevin A. Kincare, \\ Richard R. Pavey, and Byron D. Stone
}

\section{SUMMARY \\ PROBLEM STATEMENT}

Planners need to evaluate complex and competing public-policy options for managing water, land, and biological resources; they must ensure economic growth, meet the needs of an increasing population, assess hazards, and manage the environment in a sustainable manner. The State Geological Surveys of Illinois, Indiana, Michigan, and Ohio and the U.S. Geological Survey (USGS) receive many requests from local, State, and Federal planners and officials for geologic information. Thick and complex layers of glacial and related sediments blanket the bedrock of these States: a three-dimensional understanding of these deposits is critical to making informed resource-management and other planning decisions.

At two recent forums (in Indianapolis, March 1997, and Columbus, Ohio, February 1999), more than 200 attendees from more than 60 local, State, and Federal agencies provided a clear message. They need three-dimensional geologic information to use in making decisions on the following issues:

- Quality, quantity, distribution, and accessibility of surface and ground water

- Aggregate sources and land-use conflicts

- Energy and mineral resource management

- Environmental management and mitigation of land and water contamination

- Acceleration of the permitting processes of regulatory agencies

- Industrial, commercial, residential, and infrastructure siting and construction

- Agricultural land loss, erosion, sedimentation, and agrichemical use

- Waste-disposal planning and mitigation

- Habitat alteration and biodiversity

- Coastal erosion, landslides, radon, floods, and earthquakes

\section{CENTRAL GREAT LAKES GEOLOGIC MAPPING COALITION-ADDRESSING GEOLOGIC MAPPING NEEDS}

During the past million years, continental ice sheets repeatedly advanced and retreated over the central Great Lakes region, leaving deposits of mud, clay, sand, and gravel that are commonly thicker than 100 feet. A three-dimensional knowledge of the characteristics, distribution, and thickness of these deposits is required to address the above issues. Because Illinois, Indiana, Michigan, and Ohio have a similar geologic heritage and need to address common issues, the four State Geological Surveys and the USGS are collaborating to prepare three-dimensional surficial geologic maps to meet the needs of the user community.

Less than 2 percent of the land area of the four States is depicted on glacial geologic maps that contain sufficient detail to provide data for making informed decisions. Even the most detailed traditional two-dimensional glacial geologic maps do not provide sufficient information to resolve most current management issues; three-dimensional information is required. However, the third dimension of glacial deposits cannot be mapped by conventional geological methods; expensive drilling and geophysical techniques must be used.

The four State Geological Surveys and the USGS have joined to form the Central Great Lakes Geologic Mapping Coalition because timely production of this geologic information requires resources and capabilities beyond those available to any of the individual organizations. In this report and succeeding documents, the Coalition will develop a collaborative agreement that describes the roles and responsibilities of each Survey, including mechanisms to determine priorities, work plans, data management alternatives, sharing of equipment and personnel, field and laboratory protocols, and deliverables. The mission of the Coalition is to produce, in partnership with geologic information users, detailed, three-dimensional surficial geologic maps and derivative products, in digital formats from dynamic data bases, in order to enable the various user communities to derive maximum benefit from these products. 
The ability of the users to utilize the geologic information will be enhanced by significant education and interaction with the Coalition.

The four State Geological Surveys have a history of directly interacting with the user community and providing information support for decisionmakers and have invaluable background information on the geology of the area. Each has capabilities, highly qualified staff, and extensive contacts with State and local governments and private organizations. The USGS has an important role in the program, in terms of its responsibilities to Federal facilities and lands in the region, of providing a regional perspective for the mapping and contributing technical resources without which the program would not be feasible. The USGS also is interested in developing this cooperative interagency model for threedimensional geologic mapping, extending it to similar efforts in other regions of the country, and eventually developing a systematic understanding of glacial and other surficial geologic terranes nationwide. The USGS will benefit from increased outreach and interaction with the State Geological Surveys and with nongeologist information users.

All five organizations will benefit equally from the development of the information and decision-support system and the education/outreach model that are central features of this program. Both will enable the five organizations to serve their constituent communities effectively and efficiently. However, none of the five organizations has the resources to pursue a program of this scope without the support of all the others. Each brings unique resources to the program; each requires the resources of the others.

\section{THREE-YEAR PILOT-STUDY PHASE AND THE FOURTEEN-YEAR INTENSIVE MAPPING PHASE}

The proposed program consists of two phases-a pilotstudy phase and an intensive mapping phase. In the initial 3year pilot-study phase, the geological surveys will begin three-dimensional geologic mapping in high-priority areas, train personnel, expand laboratory capabilities, develop field, analytical, and mapping protocols, and initiate a geologic information delivery system that may be used as a decisionsupport system, not just a geographic information system (GIS). The program participants will develop relational data bases of both geologic and societal data connected to stateof-the-art software for specialized three-dimensional geologic visualization and analysis, geophysical applications, GIS, cartography, geologic illustrations, and geostatistics. The pilot projects will produce effective models of communication among geological survey scientists, decisionmakers, and the public. An economic assessment of the value of the pilot projects to critical societal problems will be completed.

Following pilot studies, a collaborative, 14-year intensive surficial geologic mapping phase will be conducted in 17 prioritized areas where resource, environmental, and hazard issues are particularly challenging (fig. 1). Earth scientists

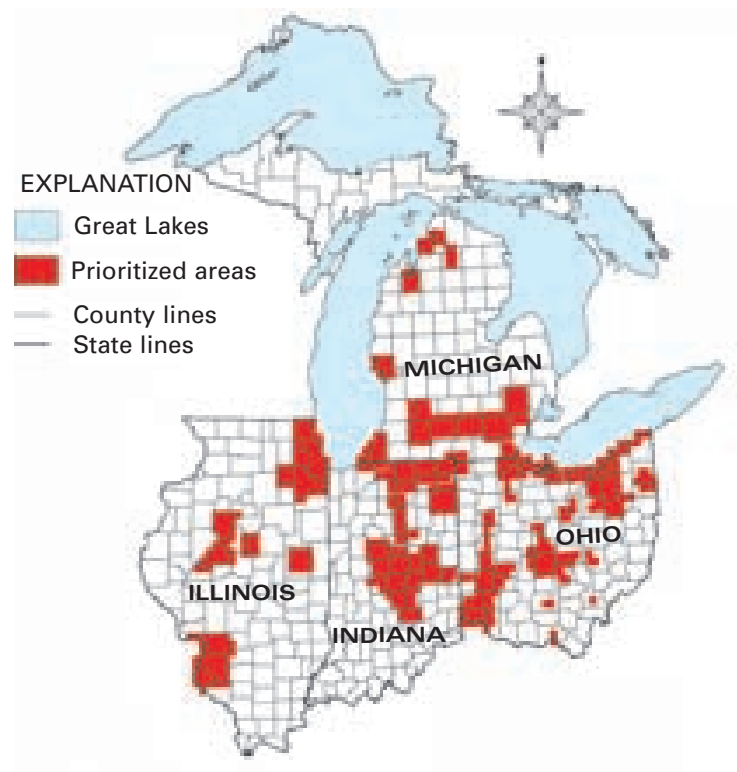

Figure 1. Proposed prioritized study areas in the Central Great Lakes States. These areas were determined by customers.

from the Coalition teams will produce basic and derivative map products and will interact with users to apply these products to real-world problems. A Scientific Steering Committee, composed of the four State Geologists, the Chief Scientist of the USGS Eastern Earth Surface Processes Team, and scientists from each survey, will provide management oversight of the program. A Project Coordination Team, composed of team members from the five surveys, will manage collaborative planning and operations in the program. This will be accomplished with the aid of a Liaison Committee composed of State and Federal education/outreach staff and members of the user community, as well as advisory committees for STATEMAP projects in the National Cooperative Geologic Mapping Program. In addition, as each project area is mapped, economic benefits of the mapping will be tracked, and societal impacts will be evaluated. The Coalition must know who is using the earth-science information, and to what degree it is being used, and must provide sound economic data on detailed benefits derived from its use.

\section{STAFFING THE PROGRAM TEAMS}

The program will require staffing and training of new personnel by all five geological surveys. Each map-project team will be balanced between field geologists and supporting specialists. At full implementation, 40 surficial geologists (including as many as 20 existing retrained staff), about 8 from each survey, will be joined by GIS and database specialists, technical illustrators and editors, laboratory technicians, drillers, and education/outreach specialists who will facilitate the novel scientist-decisionmaker interface. Collaborative interaction among Coalition members will minimize costs and duplication of capabilities. 


\section{COSTS OF THE PROGRAM}

The annual total costs of the fully implemented pilotstudy phase and the intensive geologic mapping phase are projected to be about $\$ 6.7$ million and $\$ 11.9$ million, respectively. Annual support from existing programs of the five surveys will range up to about $\$ 1$ million and $\$ 2$ million for the pilot and intensive mapping phases, respectively. Costs of new equipment and personnel, field studies, and publications are spread over the 17-year program.

\section{EXPECTED OUTCOMES, BENEFITS, AND PRODUCTS}

The expected outcome is information on natural resource, hazard, and environmental issues to support costeffective policy decisions that protect life and property, reduce the risk of economic and environmental loss, and promote sustained growth in the region. Benefit-cost analyses from other geologic mapping programs indicate that this program could realize values between 10:1 and 50:1.

This three-dimensional geologic mapping program will provide scientific information to support the following benefits:

- Science-based development and environmental planning that avoids environmental problems, such as ground-water and surface-water contamination, and loss of life and property from geologic hazards

- $\quad$ Strategies for agricultural chemical applications and manure management

- An inexpensive screening tool for selecting appropriate sites for industrial development, waste disposal, new airport and highway construction, major public land acquisition, and location of refuges and parks

- A powerful tool for public education in issues of resources, hazards, and environment

- Training opportunities for students and professional scientists in the program

- Enhanced State and Federal collaboration and increased interaction by survey scientists with geologic information users

The primary products of the Coalition's mapping program will include the following:

- $\quad$ Paper and digital geologic map products for prioritized areas

- Digital three-dimensional models of the geology derived from the basic map products for high-priority areas

- A geologic information delivery system that contains coordinated, updatable data bases with geologic data and other information in readily accessible formats to create a support mechanism for planning and decisionmaking
- $\quad$ Custom derivative maps and models, designed by map users and Coalition staff, for areas of critical societal problems, such as sustainable growth with expanding population demands, water and aggregate resources, environmental management, coastal erosion, floods, and earthquakes

\section{INTRODUCTION}

The Central Great Lakes region, comprising Illinois, Indiana, Michigan, and Ohio, is one of the Nation's most productive and economically important regions (figs. 1-3). It contains about one-seventh of the Nation's population, has one-fifth of the Nation's heavy industry, and produces onethird of the Nation's corn and soybeans. It is the transportation crossroads of North America and accounts for over half of the \$180-\$200 billion in annual trade between the United States and Canada. The continued economic growth and well-being of the region and the security of its population and ecology are related to fundamental issues involving land resources, geologic hazards, and environmental protection (see article 1 on the yellow pages). In the past, conflicting demands on land, water, mineral, and biological resources and inadequate information concerning the relationships among these resources resulted in decisions that were not compatible with sustainable development of the region and the continued high quality of life for future generations.

At two recent forums ("Understanding the Geologic Base of Our Environmental and Economic Problems," Indianapolis, March 1997, and "21st Century Geology: Foundation for a Sustainable Future," Columbus, Ohio, February 1999), many of the more than 200 participants from more than 60 agencies clearly and repeatedly stated their need for sound geologic information. They need information in formats understandable to the nonscientist as a basis for evaluating their options in the public-policy decisionmaking process. Their comments and comments of others are in the box on p. 4. Their decisions will be needed on the following issues in the Central Great Lakes region:

- Quality, quantity, distribution, and accessibility of surface and ground water

- Aggregate sources and land-use conflicts

- Energy and mineral resource management

- Environmental management and mitigation of land and water contamination

- Acceleration of the permitting process of regulatory agencies

- Industrial, commercial, residential, and infrastructure siting and construction

- Agricultural land loss, erosion, sedimentation, and agrichemical use

- Waste-disposal planning and mitigation

- Habitat alteration and biodiversity

- Coastal erosion, landslides, radon, floods, and earthquakes 

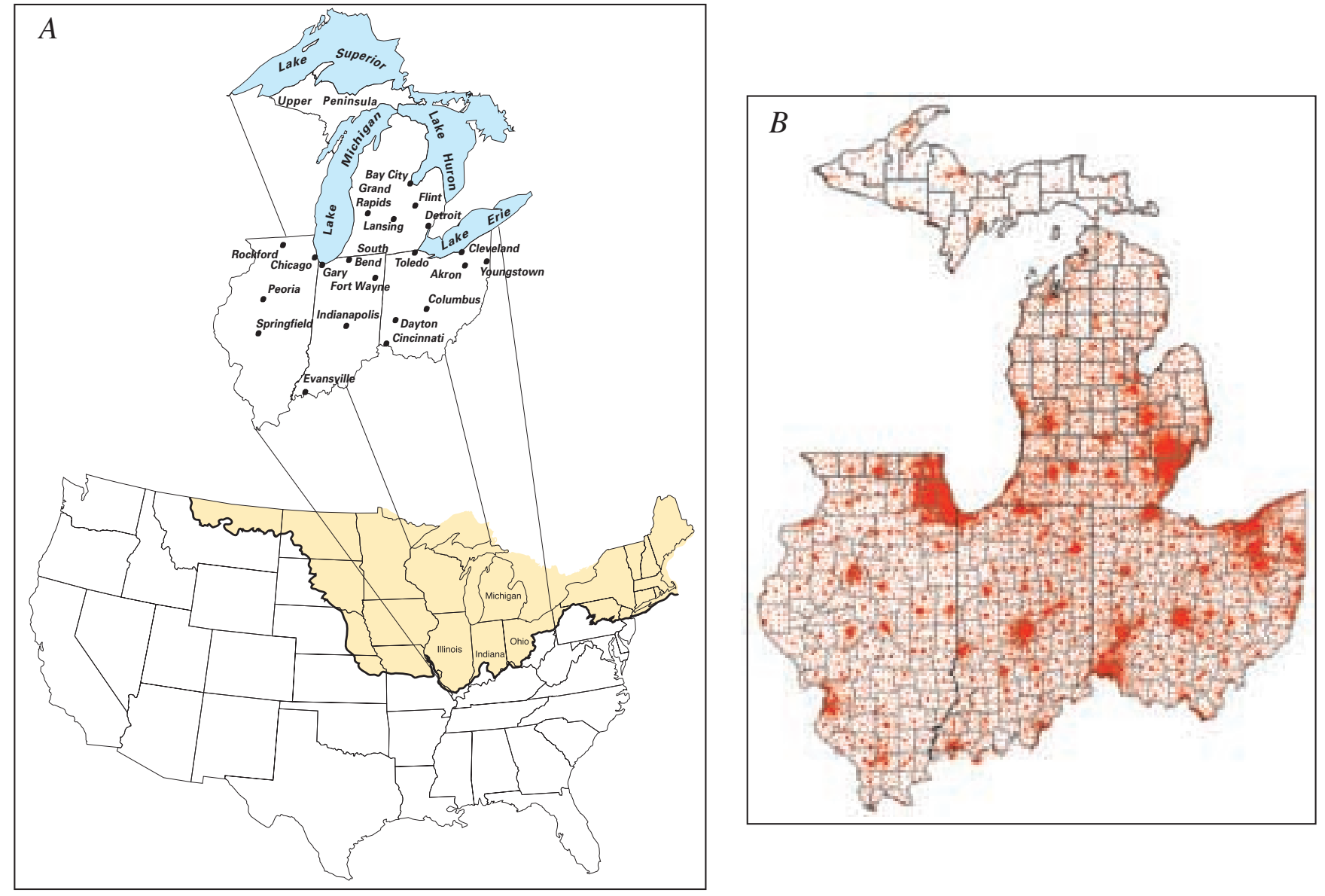

Figure 2. A, Location of the four Central Great Lakes States. The heavy line shows the southern extent of continental glaciation in the United States (from Soller, 1998). B, Location of population centers in the Central Great Lakes region (data from U.S. Census Bureau).

\section{Decisionmakers request geologic map data}

T. Elliot-Insurance Underwriter, State Farm Insurance: "The insurance industry is just now coming to realize the importance of geologic information for assessing their exposure to risk"

E.J. Fellows-U.S. Environmental Protection Agency:

"For the National Watershed Assessment Project, geology is the major missing data layer."

T.H. Tear-Director of Conservation Science, The Nature Conservancy of Illinois:

"There has been a high rate of failure of restoring wetlands because sites have been selected that do not properly link the site hydrology to its geologic setting. In response to this, the Illinois Nature Conservancy has identified several areas that would be ideal to accomplish their restoration goals and insist that sites be in 'geologically appropriate' areas. Working with the Geological Survey in the early stages is important, and should be seen as an essential and primary step in developing successful restoration projects."
R. Duncan-Indiana Department of Environmental Management: "Delineation of 5-year travel time [of ground water] requires the use of geology to see where the regulations need to be applied."

S. Esling-Associate Professor of Geology, Southern Illinois University: "The original attempt at siting a low-level nuclear waste repository failed because geology did not play a big enough role in the process."

B. Grant-Toxicologist, LaGrange County Health Department, Indiana: "We run centuries old disposal methods of septic systems and manure spreading on much higher densities than ever intended."

T. Bruns-Director of Development Services, Indianapolis Water Co.: "You need to define geology and make it available in digital data bases to serve customers."

M. Johnson-Vice President, Northern Illinois Water Corp.:

"Regional geologic mapping is critical to integrated management of aquifers." 

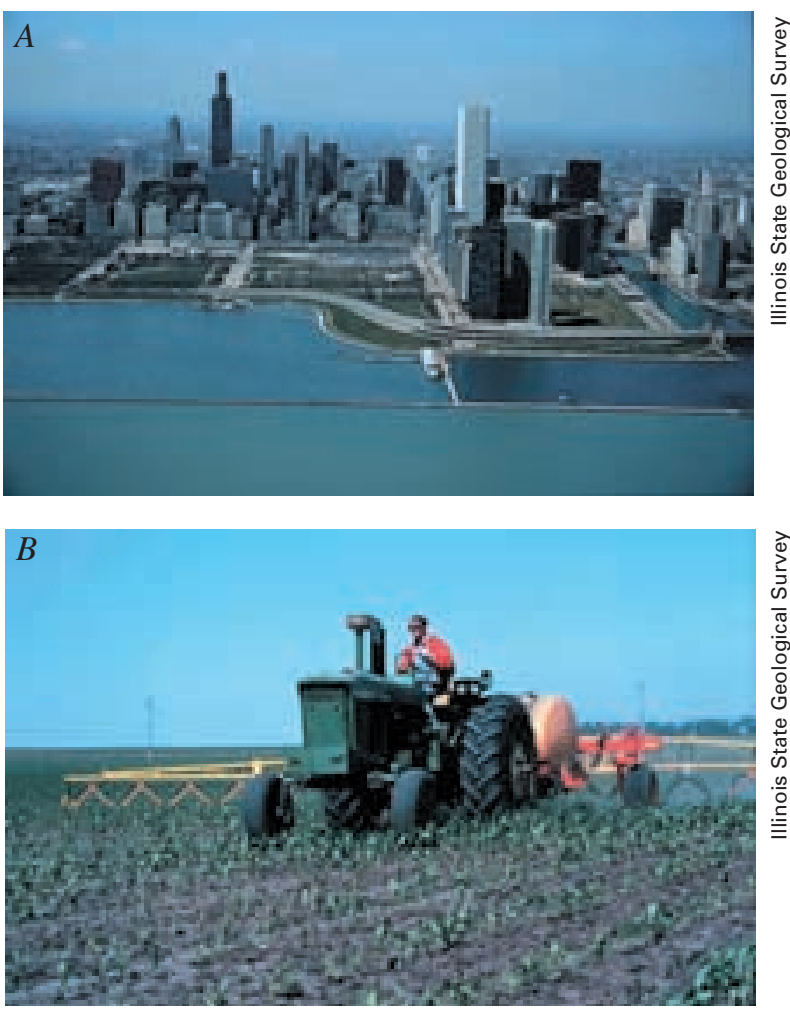

Figure 3. Urban land $(A)$ and agricultural land $(B)$ in the Central Great Lakes States.

Recent studies (Berg and others, 1984; Curry and others, 1997; Bernknopf and others, 1993; and Stone and others, in press) show that the use of modern three-dimensional geologic information can improve significantly the quality of resource-utilization decisions. This is particularly true when the geologic information is integrated with land-use and demographic information. Such information can be used objectively to support policy decisions in sensitive environments and avoid overregulation in less sensitive areas.

In contrast to other areas of the country, the Central Great Lakes region has a landscape of thick, unconsolidated materials deposited by glaciers in the last ice age (see definitions in box at right and in the Glossary). These deposits influence resource, environmental, and hazard issues and require specialized techniques for geologic investigations. The results of these investigations are depicted on geologic maps. In this region, detailed geologic maps (at a scale of $1: 24,000$, or 1 inch represents 2,000 feet) are necessary to show the complex, three-dimensional variability of geologic materials in sufficient detail to provide accurate information for planning. Regional summary maps at broader scales (typically at scales of $1: 100,000$ to $1: 1,000,000)$ provide context to address countywide, Statewide, and interstate to international planning issues.

Unfortunately, less than 2 percent of the region has been mapped at the detail needed for today's decisionmaking because these deposits are generally thick, extensive, and complex. Even where information exists, it is unavailable in modern electronic format and is difficult to access and combine with other critical decision-supporting information such as land-use and demographic data. Today's transfer of information from scientific to user communities must be modern and sophisticated and yet provide a readily understandable decision-support system that today's publicand private-sector policymakers consider essential.

In response to this need and because of the inadequacy of existing and potential resources to address it, the State Geological Surveys of Illinois, Indiana, Michigan, and Ohio have joined with the U.S. Geological Survey (USGS) to propose a cooperative geologic mapping effort that incorporates the following:

- A model of State-Federal resource-sharing, which leverages individually inadequate resources to achieve the three-dimensional mapping goal

- The development of a geologic information delivery system that includes greatly enhanced communication between scientists and the public and private sectors

\section{Some definitions ...}

Glacial geology is the study of gravel, sand, silt, and clay deposited by glaciers or meltwater from glaciers. In the Central Great Lakes region, these deposits contain the numerous highly productive aquifers, construction aggregate materials, foundation materials, parent materials of the highly productive agricultural soils, and the host media for municipal and hazardous waste sites.

Surficial geology is a discipline that includes glacial geology and the study of other unconsolidated materials produced by weathering of bedrock or deposition by streams, lakes, wind, and slope movement.

Glacial and other surficial materials in the region overlie hard bedrock and range from a few feet to over 1,300 feet in thickness. These are the materials most strongly affecting human activities.

Surficial geologists are earth scientists who study unconsolidated materials resulting from erosional and depositional processes at the Earth's surface (Earth-surface processes). Surficial geologists also have experience in related specialties such as geomorphology, stratigraphy, soil science, sedimentology, hydrogeology, civil engineering, and geochemical studies.

\section{THE CENTRAL GREAT LAKES GEOLOGIC MAPPING COALITION AND ITS MISSION}

To address the increasing needs for comprehensive geologic information, the Geological Surveys of Illinois, Indiana, Michigan, and Ohio have joined with the U.S. Geological Survey to form the Central Great Lakes Geologic Mapping Coalition. The mission of the Coalition is twofold: (1) to develop, in partnership with map users, a dynamic data base of comprehensive geologic information and to create updatable, three-dimensional geologic maps and map products that delineate in detail the surficial deposits down to the bedrock surface of the region, and (2) to produce, with partner groups, derivative map folios, assessments, and economic analyses that directly support critical decisions concerning natural resources, hazards, and environmental management in the region. 
The four State Geological Surveys for years have responded to mandates requiring them to directly interact with the user community on a regular basis in dealing with societal problems. The State Geological Surveys further recognize the important role of the USGS in the large and comprehensive Central Great Lakes Geologic Mapping Coalition program. The USGS has a unique role in synthesizing the detailed data produced in this program into regional maps spanning several States. No single State has the mandate, skills, or resources to perform such a synthesis. Regional-scale understanding of the glacial geology of these four States will provide basic understanding of the entire glacial terrane of the northern United States and thus will expand the understanding of resources, hazards, and environment on a national scale.

The five agencies all bring unique resources that allow the program to be conducted more cost-effectively than if the work were done solely by the States or by the USGS. The USGS is interested in seeing this cooperative interagency model expanded to other regions of the country. This new pattern of State-Federal cooperation will be used to leverage both Federal and State dollars for more cost-effective ways of meeting mutual data needs, and it may be a model for other geologic, hydrologic, biological, and cartographic investigations in the future. The tools developed cooperatively in this program will be significant in future USGS projects, so it is advantageous for the USGS to codevelop and co-own these tools. The USGS will benefit from outreach, education, and interaction with the State surveys and with information users from public and private sectors. Finally, the four Coalition States contain numerous federally owned facilities, such as military bases, National Forests, National Lakeshores, recreation areas, wildlife preserves, and office buildings. These Federal facilities provide a strong proprietary basis for USGS participation in gathering and analyzing data concerning resources, the environment, and hazards in these States.

\section{GOALS OF THE PROGRAM}

To meet the mission, the goals of the Coalition program are as follows:

- To conduct a comprehensive, detailed surficial geologic mapping program in high-priority areas that provides accurate geological information for solutions of societal problems pertaining to resources, hazards, and environment

- To increase the understanding of geologic processes, history, and framework in the interest of solving societal problems in the four States

- To deliver scientific information that is in formats readily usable by public policymakers and that supports sustainable development of resources and understanding of environmental and hazards issues
- To attract and train new scientists in new mapping techniques and emerging technologies

- To develop a new model of State and Federal collaboration and cooperation focused on geologic mapping

\section{PURPOSE AND SCOPE OF THIS REPORT}

This report has the following purposes:

- To describe the benefits of three-dimensional geologic map information

- To discuss new concepts and technologies relative to three-dimensional mapping, delivering information, and enabling users

- To outline the goals, implementation, and possible outcomes of an aggressive, collaborative, three-dimensional geologic mapping program

- To propose a 3-year pilot-study phase and a 14-year intensive geologic mapping phase of the program in high-priority areas

- To estimate staffing requirements and costs for full implementation of the program

- To evaluate the support capabilities of the Coalition and areas for pooling resources and equipment

- To define a model of State and Federal collaborative geologic mapping, user education, and outreach

The report provides supplemental information in the Glossary at the end and in nine articles grouped in the middle of the report, on the yellow pages.

\section{ACKNOWLEDGMENTS}

William Shilts, State Geologist of Illinois, John Steinmetz, State Geologist of Indiana, Norman Hester, State Geologist of Indiana (retired), Harold Fitch, State Geologist of Michigan, and Thomas Berg, State Geologist of Ohio, reviewed and revised this report. John Pallister (USGS), Program Coordinator of the National Cooperative Geologic Mapping Program, and Jim Quick, Chief Scientist of the USGS Eastern Earth Surface Processes Team, also reviewed and revised this report. Pat Leahy, USGS Chief Geologist, facilitated coordination of State and Federal plans for the Coalition. Federal and State reviewers included E. Donald McKay and Jonathan Goodwin (Illinois), Dennis Hull (Ohio), Steven Brown (Indiana), and Jim McNeal and David Soller (USGS). Ken Hlinka (Illinois State Water Survey), Jerry Dalsin (Illinois Department of Public Health), and R. Maier (Indiana Department of Natural Resources) supplied materials on ground-water usage. J. Treworgy (Illinois) provided information on education issues. J. Johnson (U.S. Department of Agriculture, Natural Resources Conservation Service, Illinois office) supplied data on urban expansion. S. Bhagwat (Illinois) supplied data on aggregate production. 


\section{BENEFITS OF GEOLOGIC MAPPING ECONOMIC BENEFIT-COST ANALYSIS}

The economic benefits of geologic mapping projects have been demonstrated by several recent studies:

- Within 1 year of completion of 1:24,000-scale geologic mapping of the State of Kentucky, discoveries of coal, fluorspar, petroleum, stone, and other minerals, resulting directly or indirectly from the mapping, yielded a benefit:cost ratio in excess of 50:1 (McGrain, 1979).

- The Illinois State Geological Survey conducted a geologic mapping program for Boone and Winnebago Counties, in north-central Illinois (Berg and others, 1984), emphasizing ground-water protection. A followup investigation (Bhagwat and Berg, 1991) assessed the costs and benefits of the program about 10 years after completion of mapping, including (1) reduced costs for selecting waste-disposal sites, (2) prevention of otherwise costly construction oversights, such as building subdivisions over buried peat bogs, (3) delineation of "hot spots" indicating areas where leaking underground storage tanks might be related to contamination problems, and (4) land-use zoning and ordinances developed to minimize septic-tank densities and restrict sewagesludge applications in sensitive areas. The benefit:cost ratio for the study was as much as 55:1.

- The USGS conducted an economic analysis of geologic mapping (Bernknopf and others, 1993) in Loudoun County, Virginia. This rapidly developing county west of Washington, D.C., was chosen as an example to evaluate the utility of new and improved geologic mapping in land-use decisions and assess the economic issues that determine whether a geologic map is a public good. The authors showed that a new geologic map had a future benefit-cost ratio from 10:1 to 30:1 when they considered only two future land-use decisions - the siting of a new solid-waste landfill and the siting of an interstate transportation corridor. The authors developed and applied a model of decisionmaking that explicitly used geologic maps and incorporated earth science, engineering, and economic information to transfer geologic-map information into the decisionmaking framework.

\section{EDUCATIONAL BENEFITS}

\section{PUBLIC EDUCATION}

The importance of geology was recently endorsed (July 1997) by the Illinois State Board of Education, whose new set of learning standards for the first time cites earth science, which includes geology, as a significant element of the school science curriculum for all grade levels. Students are already learning more about geology (fig. 4).
A geologic mapping program is an important educational tool. Society can become more aware of the intimate connections among Earth-surface processes, recent Earth history, earth materials and the biosphere, and the sustaining of habitats through the use of map products. For example, teachers in Boone and Winnebago Counties, Illinois, report that using new geologic maps in science classes increased science and environmental awareness of both school children and their parents. Knowledge of earth science and the use of geologic maps to mitigate environmental damage and to understand the concept of sustainable development influenced a new generation. Other public and professional educational initiatives are described in article 9 on the yellow pages.

\section{PROFESSIONAL EDUCATION}

Educational benefits extend to training a new generation of surficial geologists. At present, there is a shortage of geologists trained for three-dimensional mapping of surficial deposits. Therefore, it is important that each survey work closely with universities to promote training in surficial geology by providing practical experience to student volunteers and interns in the characterization and mapping of surficial sediments. Present staff of the five geological surveys who specialize in other areas of geology (for example, bedrock geologic mappers), which may be in less demand, may be retrained in surficial geologic mapping. The Coalition's program will provide training in the skills needed to conduct surficial geologic mapping and will encourage students to apply their training to real-world problems and to communicate effectively in the realm of public policy.

\section{ENVIRONMENTAL BENEFITS}

Modern geologic maps combined with hydrologic data constitute the information needed to allocate financial resources for specific environmental purposes, such as characterizing Superfund sites, Resource Conservation and Recovery Act sites, and brownfields (abandoned contaminated industrial lands). Three-dimensional geologic information is essential for designing cost-effective non-pointsource controls for maintaining or improving stream-water quality by identifying areas along streams containing pollutant sources and managing sources to reduce downstream water-quality impacts. Geologic maps also are vital for source-water assessment programs that are aimed at evaluating activities affecting drinking-water quality within watersheds and that consider which best-management practices may apply. Environmental concerns are discussed more in article 7 on the yellow pages.

Finally, knowledge of the three-dimensional geologic framework is essential for evaluating the water-transmitting characteristics of deposits and the relationship of deposits to the hydrologic cycle. Comprehensive ground-water flow models can assess water-use management decisions only by 


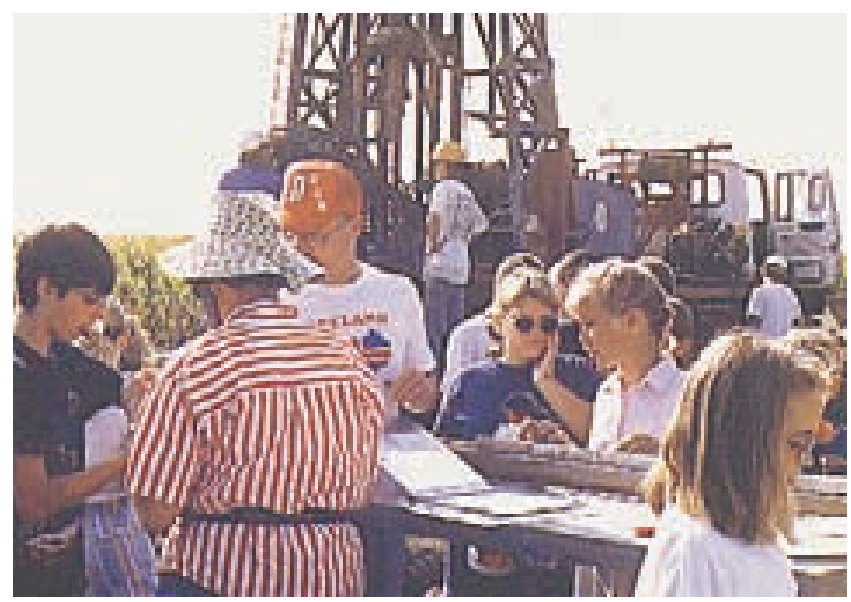

Figure 4. Students visiting geologic drill sites.

incorporating three-dimensional geologic models, accurate hydrologic and hydrogeologic parameters, and measurements of ground-water elevations.

\section{BACKGROUND}

\section{SURFICIAL GEOLOGY AND ISSUES FOR SUSTAINABLE DEVELOPMENT}

The people in the four-State region interact with land and water resources in many ways:

- Ground water from glacial aquifers provides for life itself; about 45-50 percent of the wells in Illinois and Ohio and about 60-70 percent of the wells in Indiana and Michigan draw water from glacial materials. Michigan and Ohio rank first and sixth, respectively, in total number of domestic water wells in the Nation (National Groundwater Association, 1997). In addition to drinking water, glacial materials provide the water essential for industry, agriculture, and recreation.

- Locally mined aggregate from glacial sand and gravel and the uppermost bedrock is a nonrenewable resource

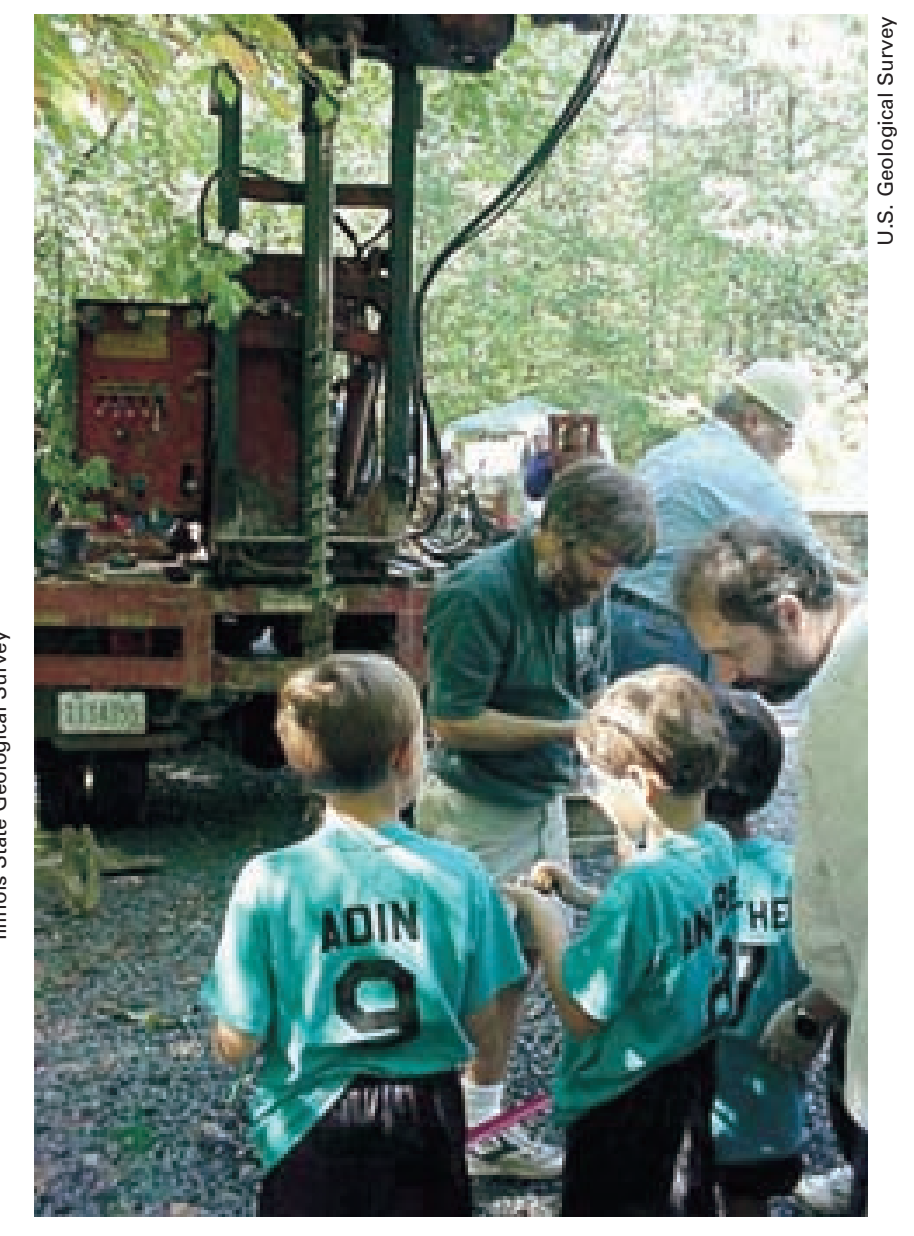

essential for construction and infrastructure development.

- $\quad$ Agriculture and forestry depend upon the geological substrate and associated soils for productivity. Some of the most highly productive soils of the world are found in this region.

- $\quad$ Siting of homes, commercial and industrial sites, transportation corridors, and waste-disposal facilities requires planners to consider hydrologic conditions and geologic hazards (such as earthquakes, landslides, and floods) associated with this glacial landscape in order to reduce risks and costs. See two examples in the box at right.

- Reclamation of mined land, sequential land-use planning, remediation of land contaminated or degraded from past use, and risk-based cleanup criteria all must be based on geologic and hydrogeologic conditions of a site or area.

- Many unique habitats are linked directly with geologic settings. In addition, a decline in wetland acreage due to competing land uses has initiated restoration activities, and geologic and hydrologic factors must be considered for restoration to work properly. 


\section{Lack of geologic data increases costs}

Decisions made without predictive geologic information may increase costs and risks to the society and the environment:

- Failure to recognize and design for karst (cavernous) terrane and thick surficial deposits along the Upper Scioto West Interceptor Sewer Project in Columbus, Ohio, caused \$14 million in unexpected cost overruns. A tunnel-boring machine collapsed into a buried cave, resulting in delays and an expensive excavation project. Presence of the subsidence hazard could have been predicted by three-dimensional characterization of materials and geophysical surveys along the project corridor.

- Lack of detailed three-dimensional geologic information in Martinsville, east-central Illinois, resulted in an unsuccessful attempt to locate and characterize a candidate site for low-level radioactive waste disposal. Detailed mapping would have shown the presence of aquifers and eliminated the site from consideration. The failed siting attempt cost about $\$ 96$ million.

\section{SURFICIAL GEOLOGY OF THE CENTRAL GREAT LAKES REGION}

Thick surficial materials deposited mostly by glaciers between about 1 million and 10,000 years ago dominate the geology of the Central Great Lakes region, entirely covering the bedrock throughout most of the four States. The surficial geology of the region spans glaciated and nonglaciated landscapes of the midcontinent (figs. 2, 5). The glaciated area contains surficial deposits, composed of fresh minerals and rock fragments deposited on the hard, glacially polished bedrock surface by continental ice sheets. Glacial-stream valleys and glacial-lake basins were filled with sorted and layered deposits during different ice advances, producing an underground maze of deposits. Beyond the glacial border, surficial materials are stream and lake sediments in valleys, wind-deposited silts (loess), weathered-rock materials, and thickened hillslope deposits (colluvium) that moved down bedrock slopes. Modern deposits created by active Earth-surface processes in streams, lakes, and sand dunes and on slopes locally cover the older materials and add to the complexity of the geology.

Despite the variety of deposits and processes that produced them, all surficial materials are characterized by their physical properties. The distinctions between fine- and coarse-grained materials and stratified and homogeneous materials (fig. 6) are important concepts in this glacial landscape. Coarse-grained, sorted, glacial meltwater deposits constitute the ubiquitous shallow aquifers and construction aggregate deposits. Fine-grained, nonsorted, glacial-ice-laid deposits form extensive layers that confine and protect underlying aquifers. Highly productive agricultural soils developed from geologic parent materials that contain mineral nutrients and have high water-retention characteristics. Ancient soils (paleosols) and stream and wind sediments buried within the deposits mark episodes between glaciations. These help

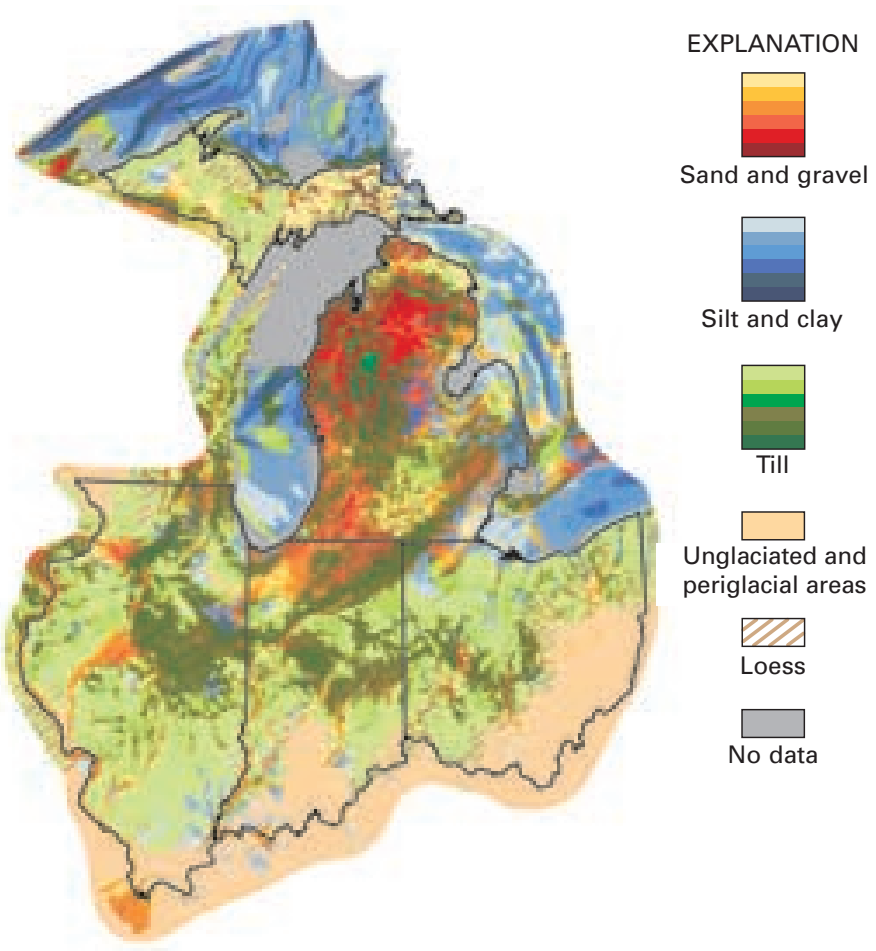

Figure 5. Glacial and related deposits of the Central Great Lakes States. Darker colors represent thicker deposits. From Soller (1998).

define individual glacial cycles within stacked deposits, and are important elements that reveal the geologic history.

Deposits from several glaciations and interglacial and postglacial events record the dynamic action of continental ice sheets, rivers, lakes, slopes, and wind (fig. 7). Surficial deposits cover the bedrock surface in thicknesses commonly of 150-400 feet but range from a few feet to more than 1,300 feet in thickness. Glacial deposits include ice-laid till, composed of a compact mixture of sand, silt, clay, and gravel (fig. 8). Glacial deposits also include sediments consisting of sorted and layered gravel, sand, silt, and clay deposited by glacial meltwater (fig. 6). Younger surficial deposits include gravel, sand, silt, and clay transported by rivers and lake currents, windblown sand in dunes and sand sheets, windblown silt (loess), and organic materials in wetlands.

\section{SURFICIAL GEOLOGIC MAPS AND NEW AND EMERGING TECHNOLOGIES}

Traditional surficial geologic maps (also known as Quaternary or glacial geology maps) show the two-dimensional distribution of glacial and other deposits at the land surface based on interpretations of the shape of individual landforms, field examination of exposed materials, and information from shallow excavations (such as roadcuts) or from drilling. These maps typically include widely spaced cross sections depicting the subsurface distribution of deposits along the line of section. Map units show areas composed of contrasting geologic materials of different ages. 


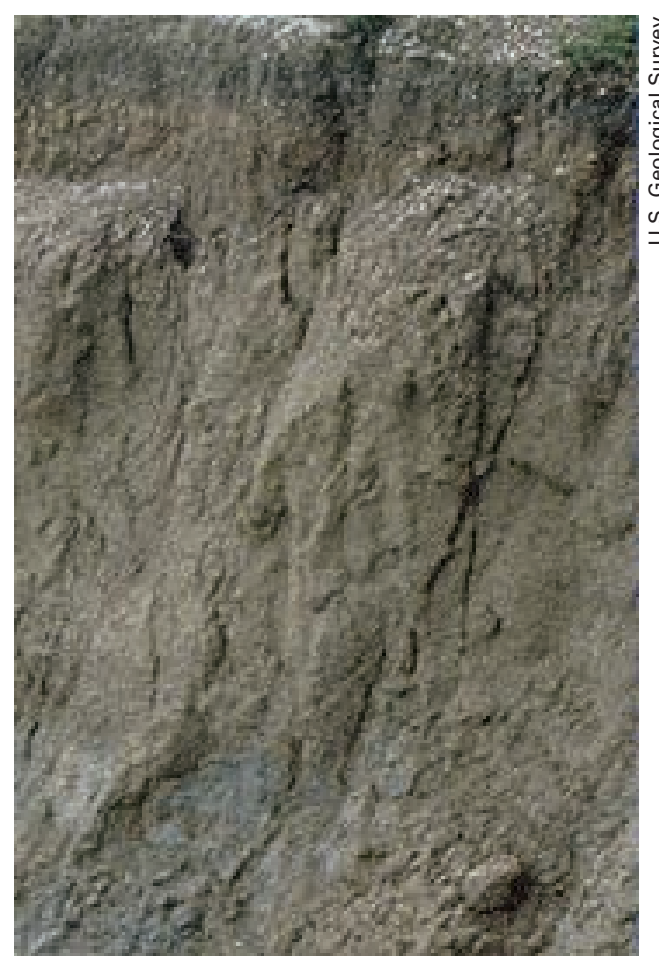

$A$

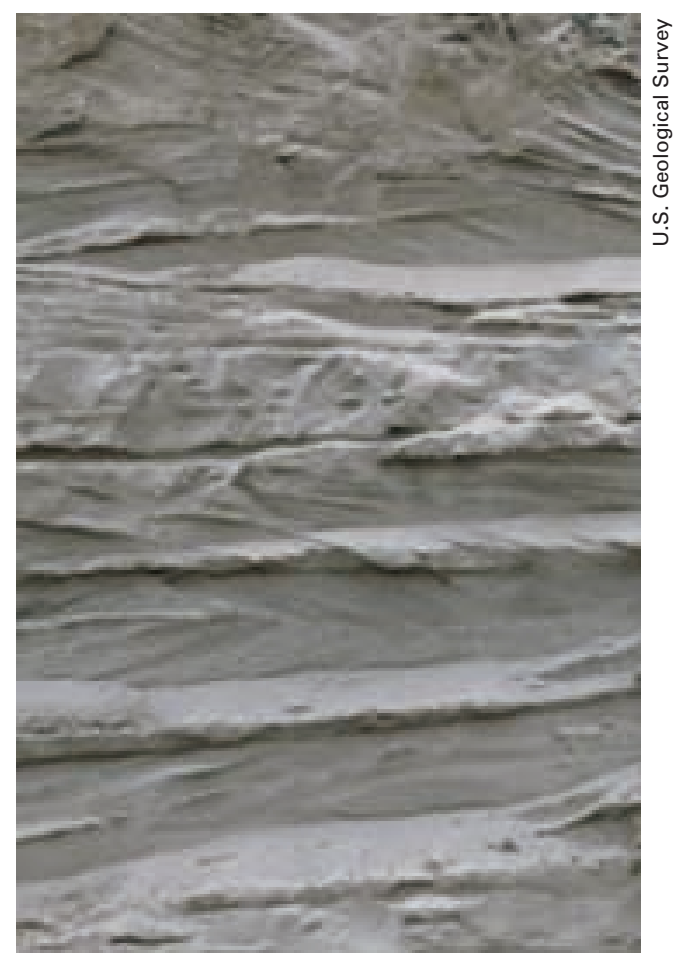

$C$

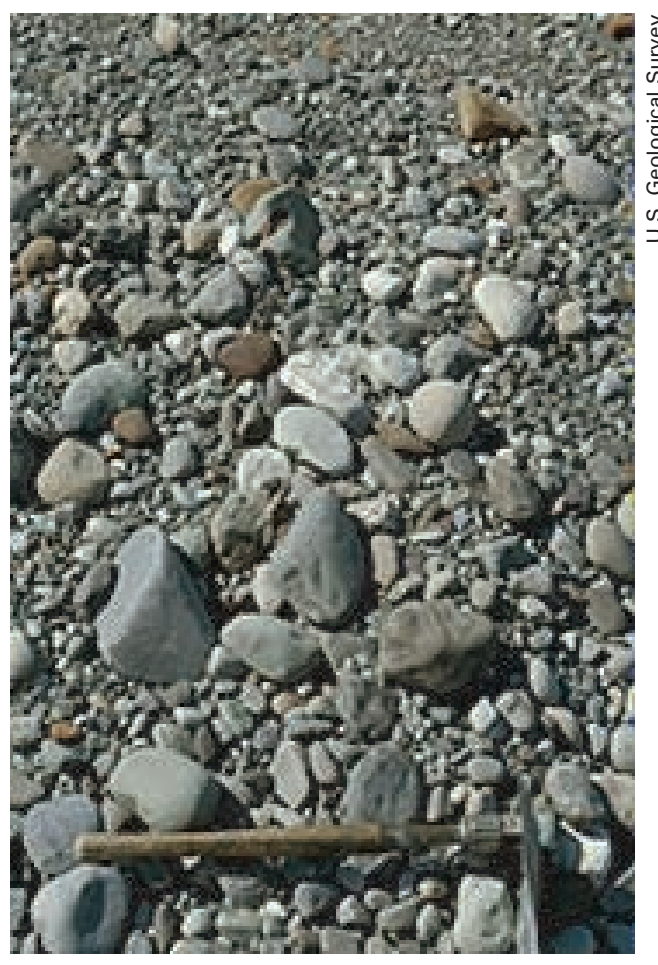

$B$

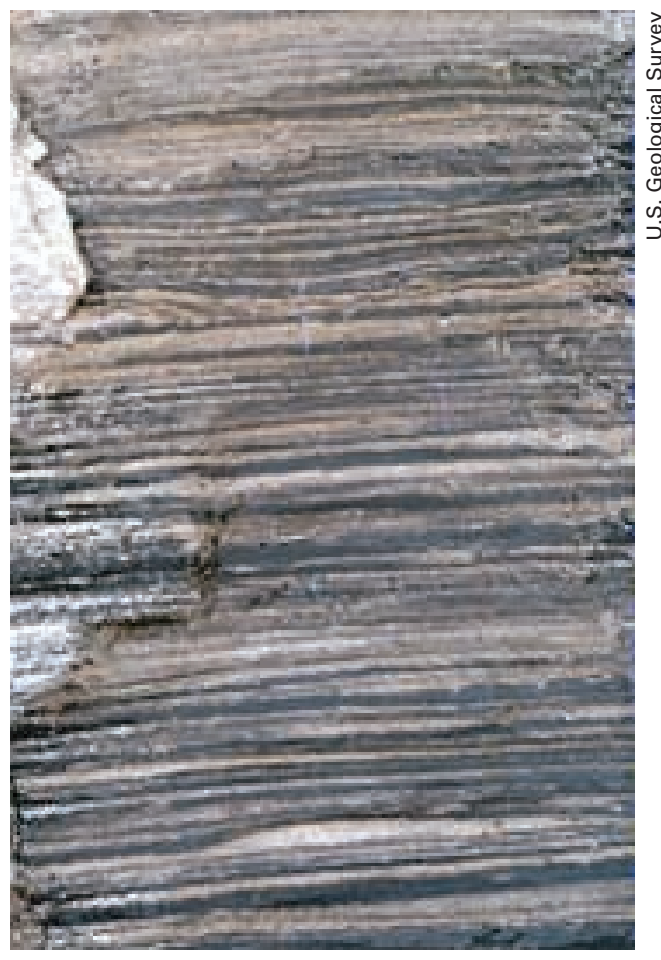

$D$

Figure 6. Examples of surficial geologic materials units having different grain sizes and degrees of sorting. $A$, Silty till, a mixture of sand, silt, and clay with scattered gravel. Vertical scale about $12 \mathrm{ft}$. B, Glacial gravel, composed of pebbles and cobbles. Shovel handle is 21 inches long. $C$, Glacial sand, sorted and crossbedded. Vertical scale about $10 \mathrm{ft}$. $D$, Glacial silt (light) and clay (dark), thinly bedded. Vertical scale about 20 inches. 


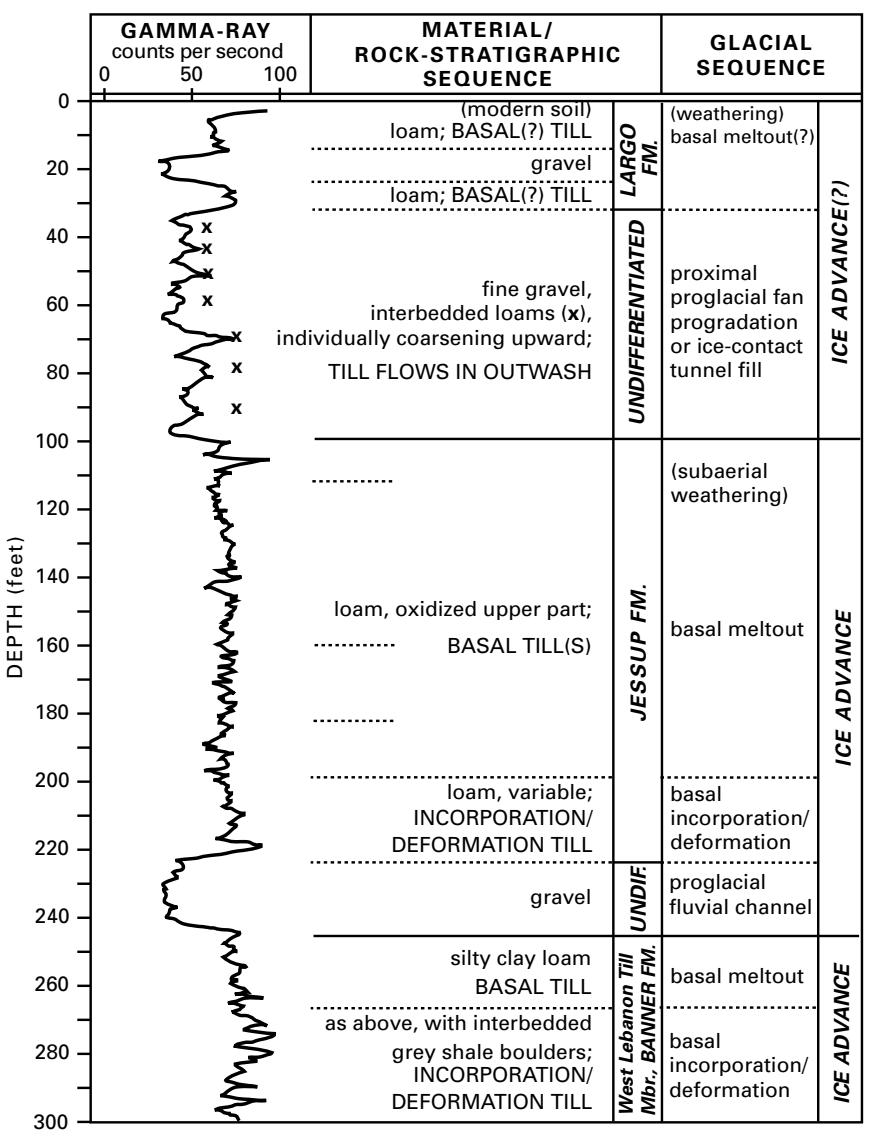

Figure 7. Geophysical record (natural gamma radiation of deposits) from the Marion Valley, east-central Indiana, showing deposits of three ice-sheet advances and retreats (data from N.K. Bleuer).

In many previous geologic mapping studies, the ages of geologic units were emphasized and refined by several generations of geologists using different concepts and methods of dating and classifying the deposits.

In the Central Great Lakes States, regional geologic maps (1:250,000 to $1: 1,000,000$ scale), based in part on old surveys (for example, Leverett and Taylor, 1915), depict the region, but the information is of highly varying quality (Soller, 1992) and in some areas is based on observations and geologic concepts more than a century old. Traditional surficial geologic maps at scales of $1: 48,000$ to $1: 125,000$ cover only about 10 percent of the region (fig. 9) and are based on old concepts and methods. Traditional surficial geologic maps at the detailed scale of 1:24,000 are available for only part of northern Illinois and scattered areas of Ohio and Indiana (fig. 10).

In contrast to traditional surficial geologic maps, modern surficial geologic maps depict the three-dimensional character of the entire sequence of geologic materials from land surface down to bedrock. Deposits are differentiated by comparing their physical properties, vertical sequences, and lateral distribution patterns with modern models of sediment deposition in glacial, river, and lake environments. Detailed

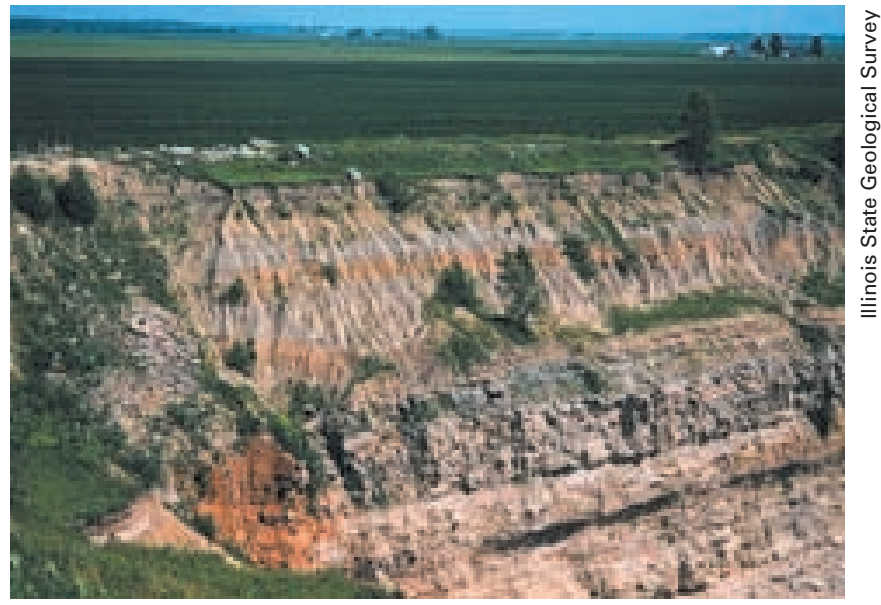

Figure 8. The 35 feet of sediment that overlies the bedrock at this Illinois quarry consists of till layers (gray zones) deposited by ice during three glacial episodes and soil layers (redder zones) that formed during interglacial episodes.

distribution of sedimentary features and grain size can be displayed on cross sections (Stone and others, in press), on block diagrams, and by using three-dimensional visualization software (Soller and others, 1999).

\section{THREE-DIMENSIONAL MAPS, MODELS, AND ANALYSES}

A three-dimensional geologic model shows the geometry of surface and subsurface geologic units. The relative positions and ages of the deposits are parts of the model, which actually add a fourth dimension: geologic time. Using new data from three-dimensional models, geologists can improve digital maps of buried units. Various perspective views can be assessed, and data can be checked for accuracy and internal consistency of units (that is, lower units can not appear above upper units). Furthermore, water-producing geologic units in such models can be input into commercial volume-modeling software to produce a three-dimensional model that shows the subsurface distribution of aquifers. Views of the geology also can be tailored for analysis by less technical map users and are used to develop derivative maps.

The oldest and most common mapping technique for showing three-dimensional relationships of geologic units is a use of a cross section, which shows the geometries of units in the subsurface and the contacts that bound their lateral extent (fig. 11). Cross sections on the sides of block diagrams (fig. 12) and multiple cross sections in fence diagrams (fig. 13) improve three-dimensional visualization. However, interpretations are incomplete between the lines of sections and are inadequate for uses like modern groundwater flow modeling. Continuous three-dimensional geologic models are required to provide realistic estimates of the variability of aquifer properties. 


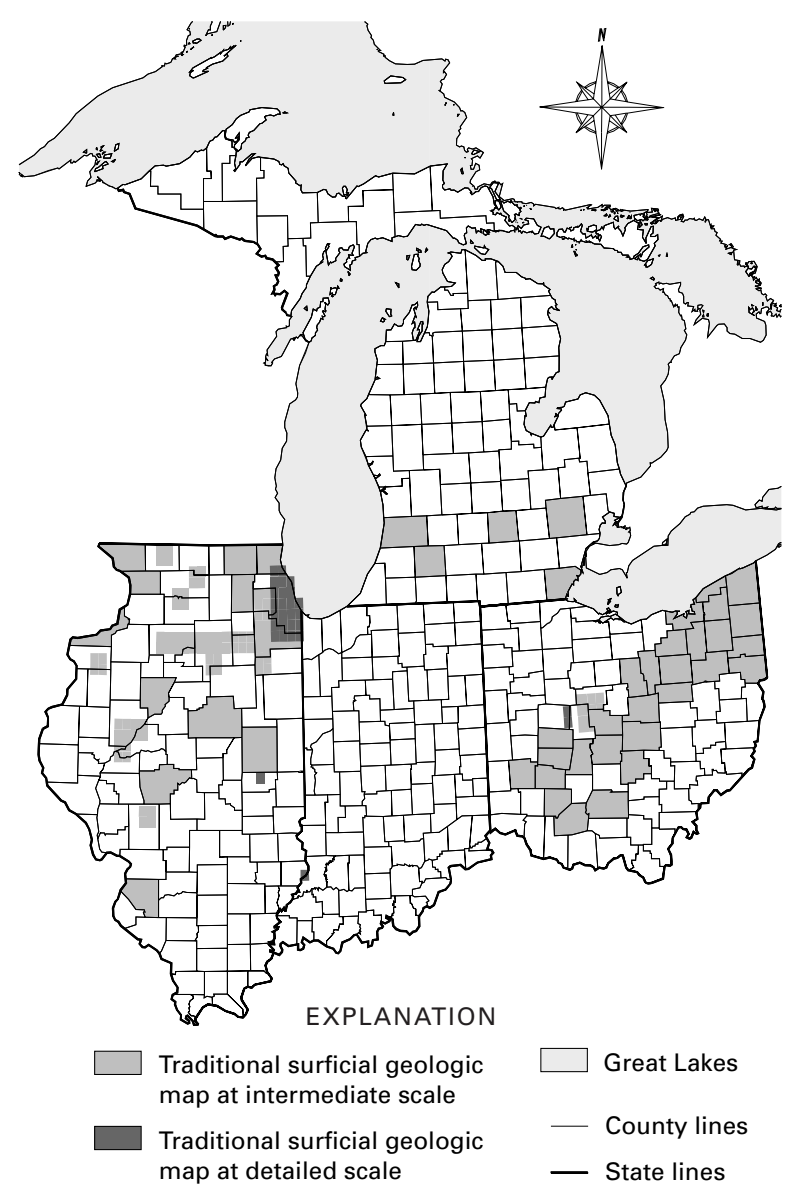

Figure 9. Areas in the Central Great Lakes States depicted on traditional surficial geologic maps at intermediate scale and detailed scale.

One method of presenting the three-dimensional geology on a map is the stack-unit method of Kempton (1981). A stack-unit map shows successions of geologic materials in their order of occurrence (from top to bottom) to a specified depth or boundary. These maps describe the vertical order of superposed units that are grouped in a mappable area (Kempton, 1981; Pavey, 1987; Curry and others, 1997). Each map area on a stack-unit map represents a unique vertical sequence of geologic units; however, the level of detail of the map is limited by the number of unique colors and unit symbols that can be shown and comprehended.

Three-dimensional geologic maps have moved into a new era with the advent of geographic information systems (GIS) and computer-assisted visualization of unit surfaces and volumes (fig. 14). Map users can generate three-dimensional views of the data at any locality of interest. Multiple cross sections (fig. 13) can be selected from a three-dimensional block of geologic information (fig. 12). Surface-elevation maps can be chosen to show the shapes and features of the tops and bottoms of buried geologic units. Depth slices can show the geologic units at a selected depth below land surface. Elevation slices can be selected to show units

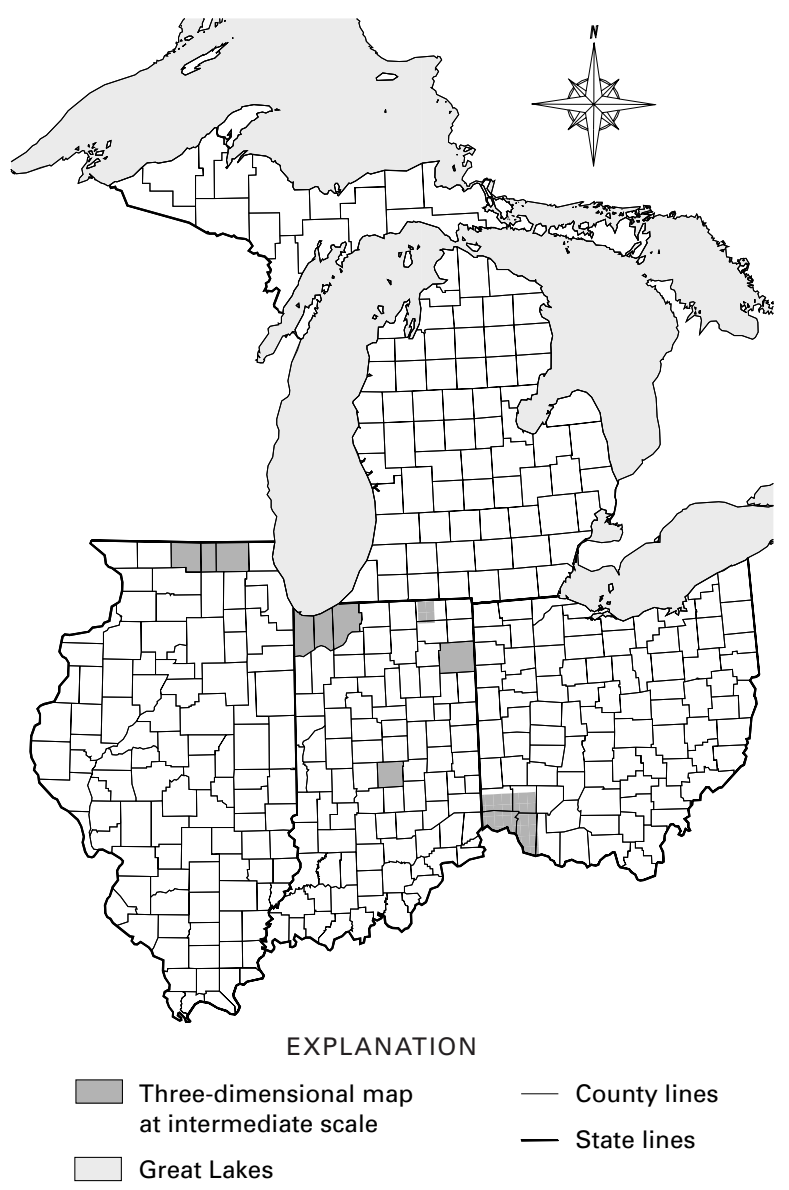

Figure 10. Areas in the Central Great Lakes States depicted on threedimensional maps, including stack-unit maps, at intermediate scale.

at a given elevation. Maps can also be produced to show the thickness of geologic units.

In many areas of complex geology where specific units cannot obviously be correlated, the contacts between units cannot be generated and surface elevation and thickness maps cannot be made. The mapping solution in these complex areas can become a "landscape model" based on the probability of finding a particular unit within a conceptual vertical sequence of materials.

\section{NEW GEOLOGIC MAPS SUPPORTED BY DIGITAL DATA BASES}

Recent advances in computer technology and geographic information systems provide scientists with new ways to organize, display, and analyze the complexities of three-dimensional geology (fig. 15). These advances are changing the function of geologic map products. For the first time, geologic, hydrologic, biologic, and demographic information can be combined in interactive three-dimensional models. The need for timely delivery of such detailed models and derivative map products is increasing. 


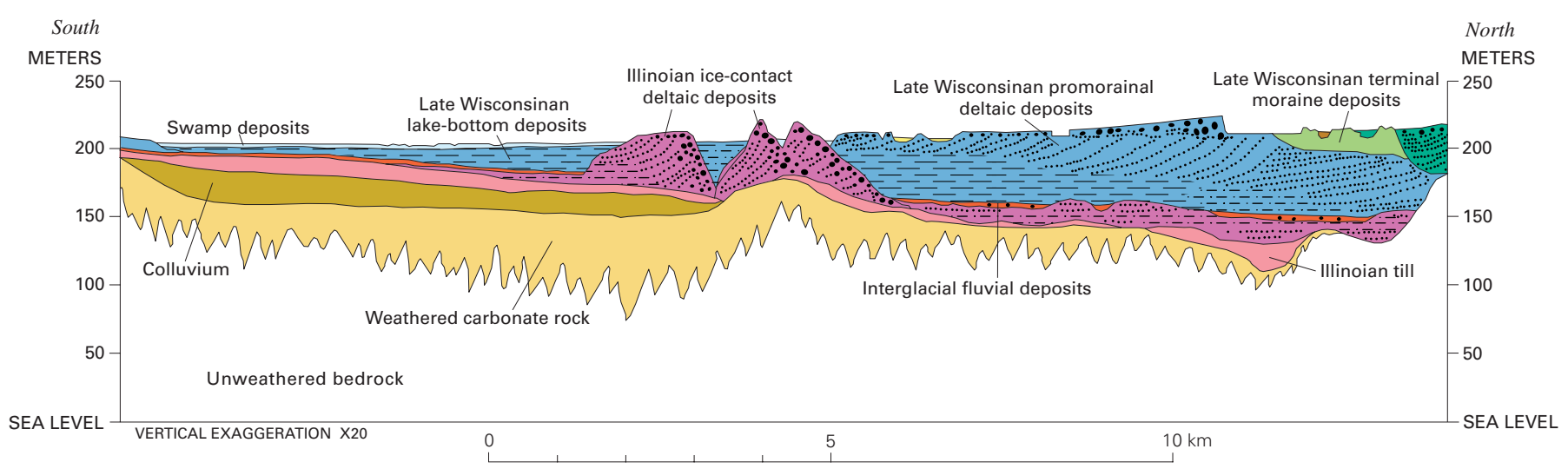

Figure 11. Interpretive cross section showing late Wisconsinan- and Illinoian-age glacial-lake deltaic deposits in a basin underlain by colluvium and weathered bedrock in central northern New Jersey (modified from Stone and others, in press, section I-I'). Late Wisconsinan deltaic deposits compose a single morphosequence deposited beneath and in front of the late Wisconsinan terminal moraine deposits. Schematic patterns for deltaic deposits show coarse gravel topset beds overlying dipping sandy foreset beds, which overlie fine-grained lake-bottom deposits. The older Illinoian deposits are exposed south of the late Wisconsinan terminal moraine and delta.

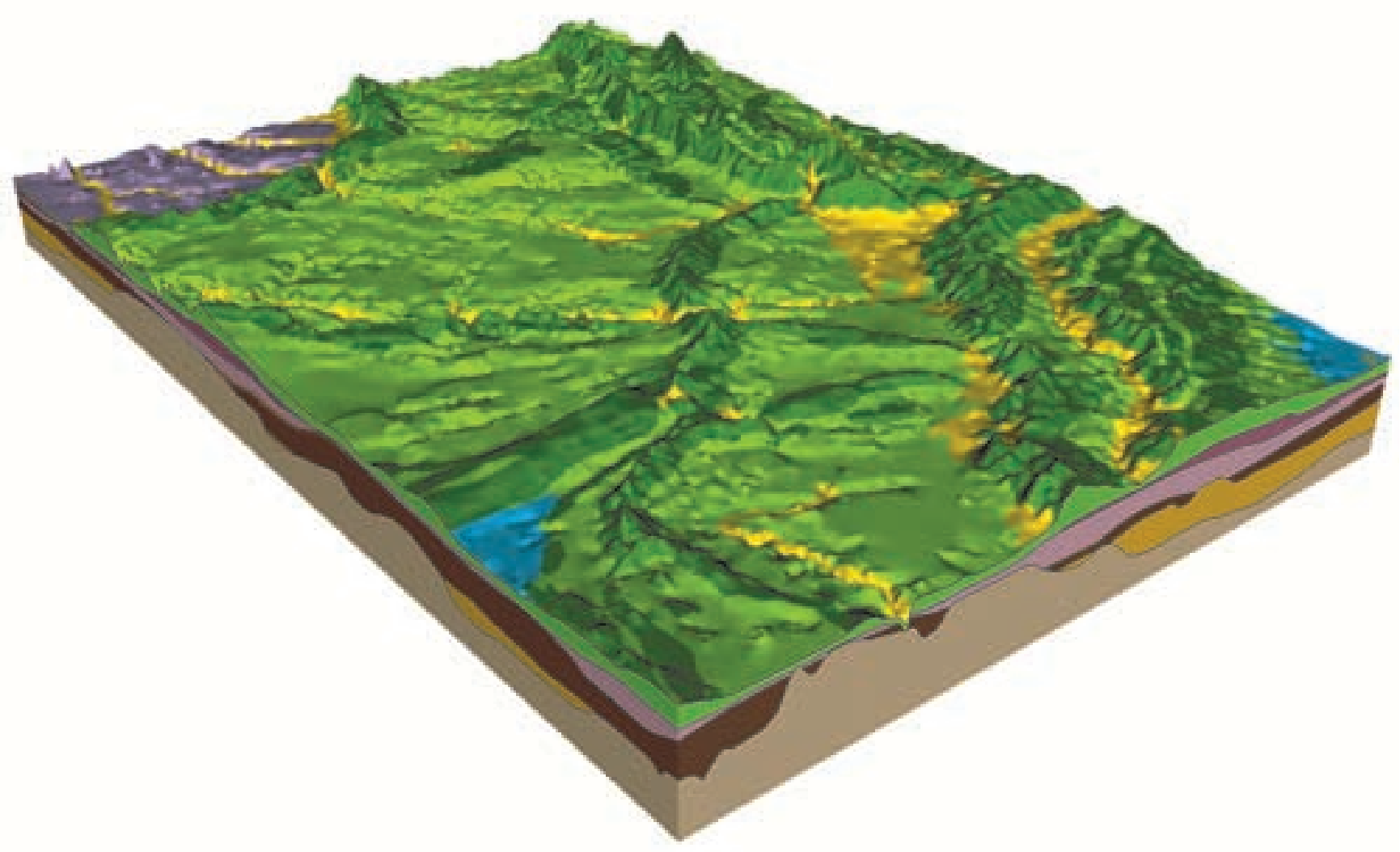

Figure 12. Block diagram of surficial deposits in east-central Illinois. From Soller and others (1999). 


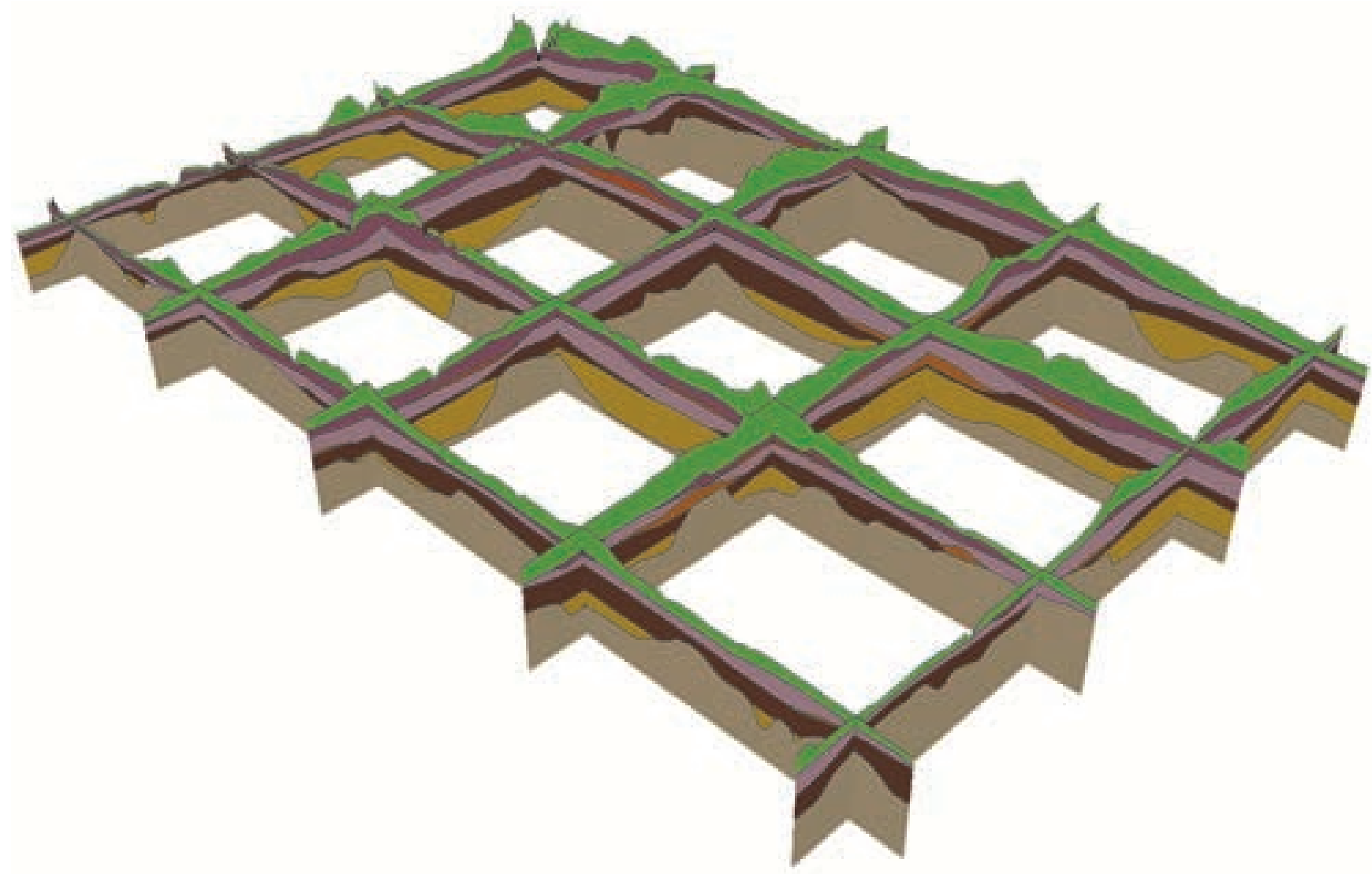

Figure 13. Fence diagram composed of nine cross sections through the surficial deposits and upper bedrock in east-central Illinois. From Soller and others (1999).

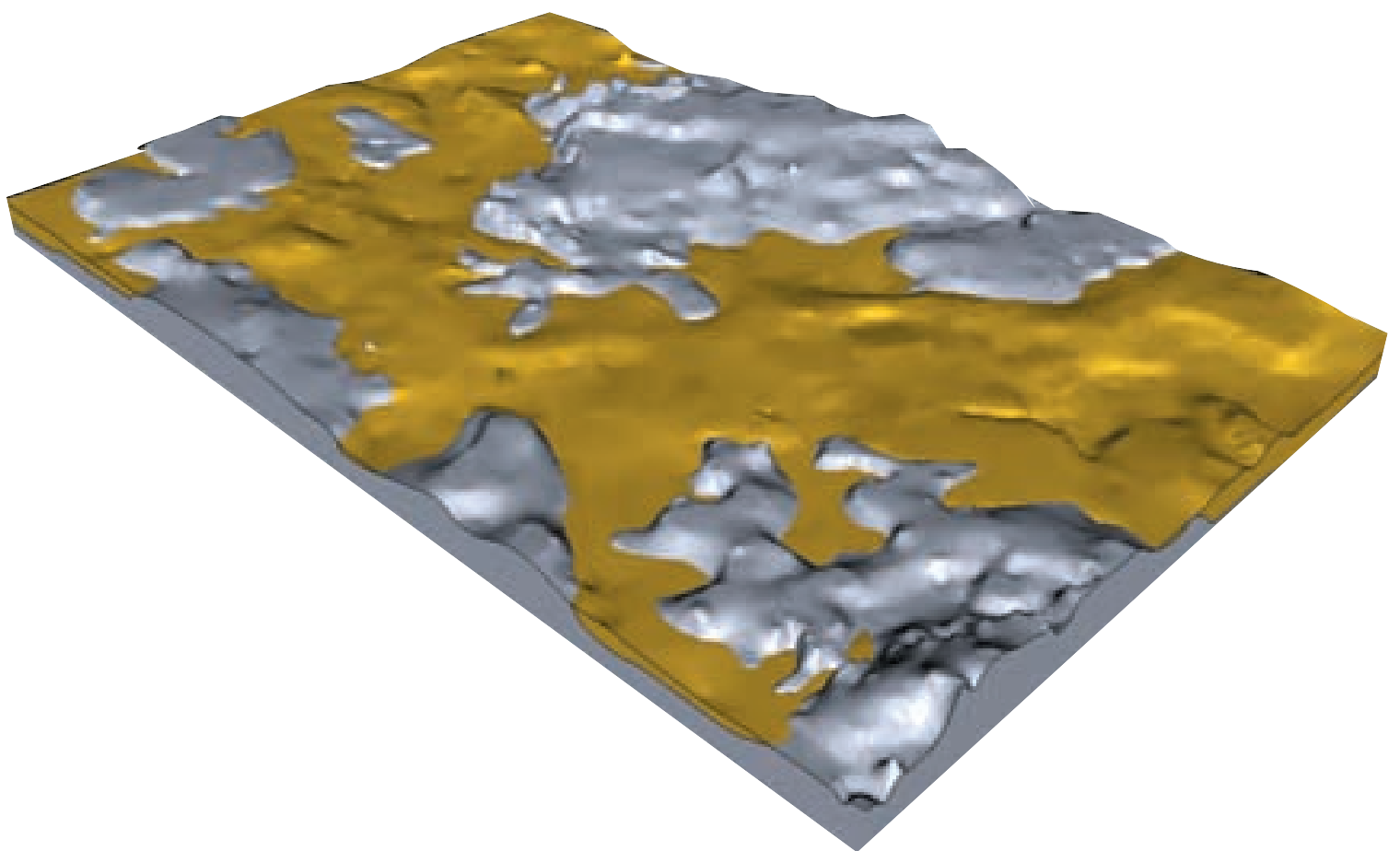

Figure 14. Block diagram showing surface-elevation map of the Mahomet Sand aquifer within a buried bedrock valley carved by glaciers and river water. From Soller and others (1999). This diagram is the second layer of figure 15. 


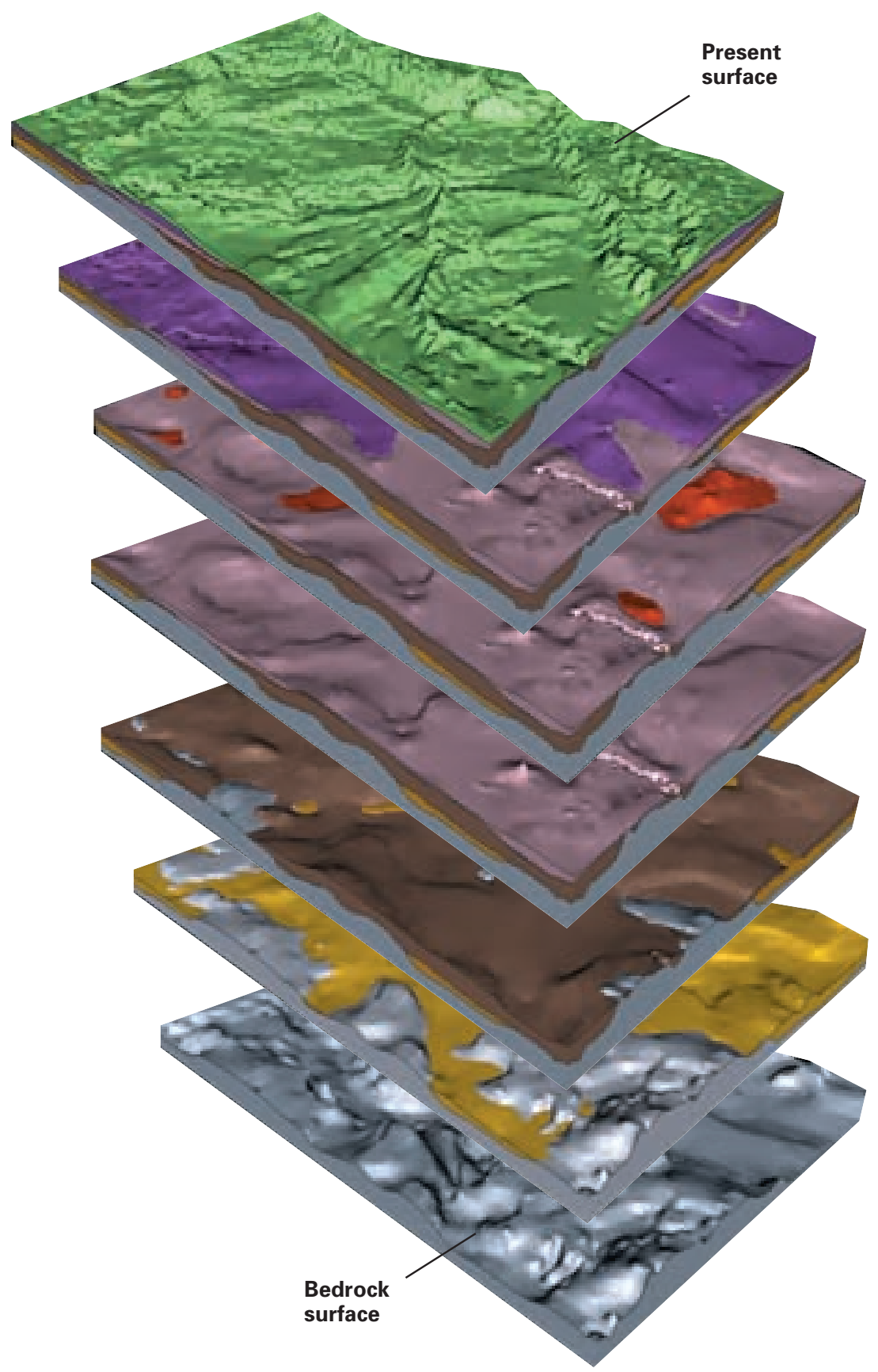

Figure 15. 3-D computer model of glacial deposits in east-central Illinois. The top image represents the present surface of the land. The bottom image represents the land's surface before glaciation. The top six layers show successive glacial deposits. From Soller and others (1999). 
Also, the digital product can be managed and updated as new data or new interpretations of old data become available. Thus, all geologic maps and three-dimensional models will be linked to a digital data base. The Coalition proposes to develop the application of such models to provide userfriendly, decision-support systems for use in planning for sustainable and environmentally friendly development.

Several related mapping concepts used in the Great Lakes region and elsewhere may be applicable to the threedimensional mapping program. Some of these are complementary and are used together in an area; some are singularly appropriate, depending upon the nature of available data and the complexity of the geology. These concepts include the following, which are discussed below:

- Glacial terrane characterization, vertical sequences, and morphosequences

- Surficial geologic materials units

- Glacial stratigraphy

- Subsurface techniques

\section{GLACIAL TERRANE CHARACTERIZATION, VERTICAL SEQUENCES, AND MORPHOSEQUENCES}

Glacial terranes are diverse, but for the purposes of this report, four general glacial terranes can be identified in the Central Great Lakes region, as well as a nonglaciated terrane that was affected by near-glacial processes (see inside back cover). This regional characterization erects a basic framework of vertical sediment sequences and a predictive model for detailed analyses. Distinctive sediment sequences, determined from regional studies of thousands of downhole geophysical logs and sample sets, are the foundation of this approach.

The morphosequence mapping concept (Koteff and Pessl, 1981) is applied to meltwater deposits at a scale of $1: 24,000$. A morphosequence is a body of meltwater deposits composed of a continuum of landforms that were deposited simultaneously at and beyond the margin of a glacier. These units are small elements of broader scale glacial terrane sequences. They summarize the overall downstream fining and sorting of sediments in each deposit and effectively can predict aquifer and aggregate-resource properties.

\section{SURFICIAL GEOLOGIC MATERIALS UNITS}

Surficial geologic materials units are described by their fundamental grain-size and sedimentary properties (fig. 6). These units include gravel, sand, silt, clay, and till and are the smallest, most basic units that can be mapped or predicted in the subsurface. They can be described uniquely in hydrogeologic, soils, or engineering classifications.

\section{GLACIAL STRATIGRAPHY}

Glacial stratigraphic units are routinely recognized by their unique characteristics of materials, sequences, or contact relationships. Certain units are the cornerstone markers within the glacial sediments and are the fundamental basis for subsurface correlations. Glacial stratigraphy provides the fundamental framework for development of the threedimensional models discussed above. Traditional largescale sequences, for instance, are those bounded by buried interglacial soils or related nonglacial sediments. The buried soils separate packages of diverse glacial sediments representing ice-sheet advance and retreat. Within these packages may be discrete till units or discrete sediment sequences that have distinct characteristics allowing their recognition and tracing over broad areas.

\section{SUBSURFACE TECHNIQUES}

Subsurface geophysical techniques used in petroleum and mineral explorations increasingly have been modified for application to ground-water and environmental assessments in the past decade. These emerging technologies will be used to help map the three-dimensional distributions of surficial deposits:

- High-resolution downhole geophysical tools measure material properties and produce images that are used to correlate subsurface geologic units; other subsurface tools produce images of the drill-hole wall and plot boundaries of subsurface units between drill holes

- Airborne surveys of electromagnetic properties and natural radiation (fig. 16) show boundaries of shallow fine-grained and coarse-grained deposits and deposits derived from contrasting sediment sources

- Profiles from ground-penetrating radar and seismic reflection can show bounding surfaces and internal characteristics of subsurface units and top of bedrock

- Electromagnetic soundings provide data to model subsurface deposits on top of bedrock

Techniques for obtaining undisturbed core samples of surficial sediments also have improved in the last decade. Vehicles to deliver these new types of coring devices to previously inaccessible areas are being developed and will be used in this project where necessary and cost-effective. New tools include the following:

- Inner-barrel coring tools in mud-rotary drill rigs that rapidly deliver core samples by wire-line retrieval from depths of at least $1,500 \mathrm{ft}$

- Power augers with locking inner-barrel coring tools that deliver oriented core samples from depths of as much as $250 \mathrm{ft}$ 


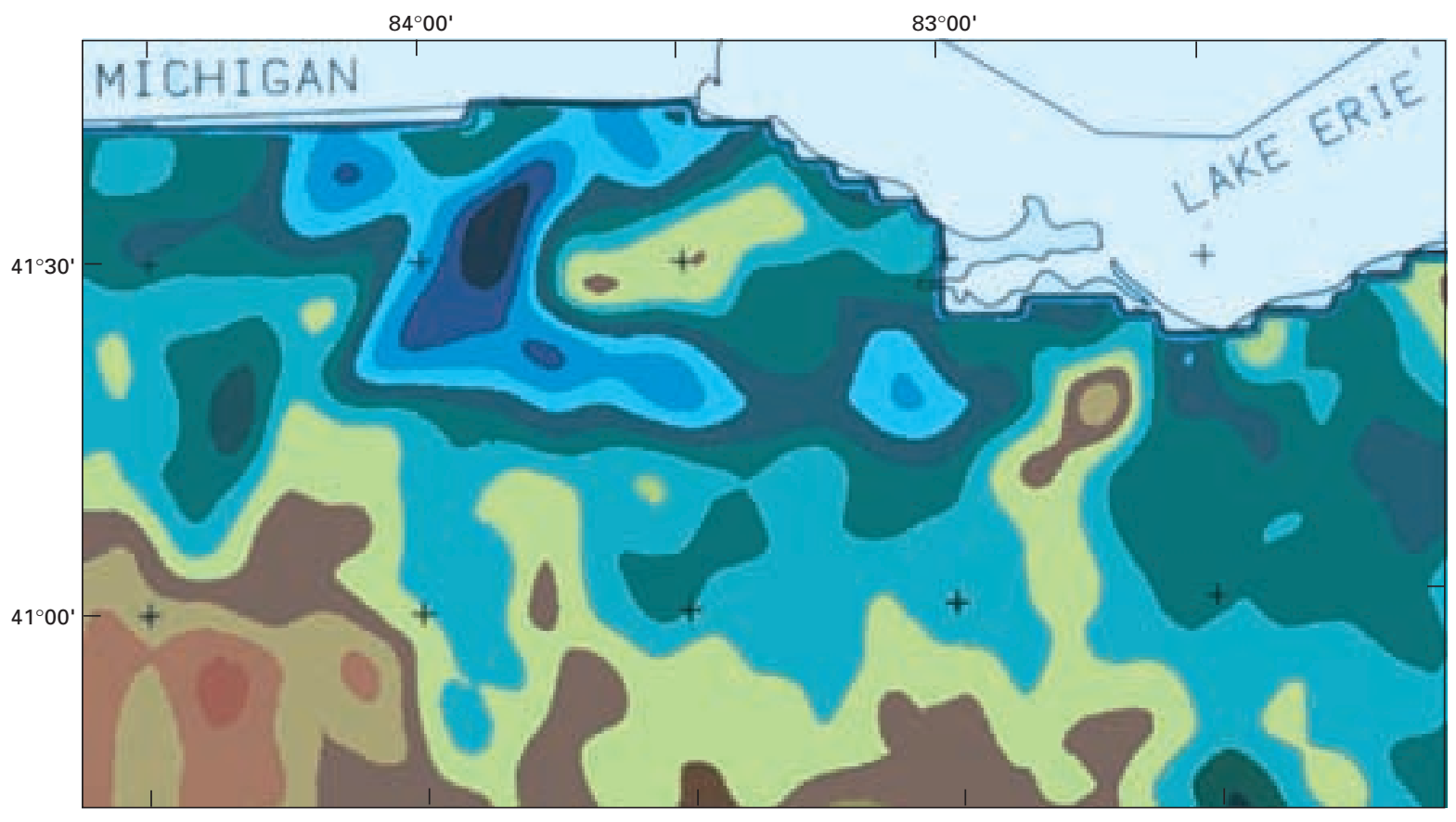

Figure 16. Map showing concentrations of uranium associated with surface materials of northwestern Ohio, based on variation of natural low-level gamma radiation from uranium (Duval, 1987). Yellow to red-brown colors indicate 2.7-3.3 parts per million ( $\mathrm{ppm}$ ) uranium in thick surface clayey till deposits derived from uranium-bearing black shale bedrock. Black to light-blue colors indicate $0.0-1.8 \mathrm{ppm}$ uranium in thick surface sand deposits. Intermediate green colors indicate 1.8-2.7 ppm uranium in thin surface sand deposits and underlying clayey till deposits.

- Sonic coring devices that deliver core samples from depths of as much as $500 \mathrm{ft}$

- Jack-up barges and Hovercraft that can be used as drilling platforms in shallow water bodies and in sensitive environments. The USGS is testing a prototype, patented coring rig mounted on a Hovercraft to be used in this program

\section{PROGRAM CONCEPTS AND APPROACH}

The Coalition members will collaborate to set uniform map quality standards for surficial geologic maps, prescribe the basic and derivative map products and data bases to be produced, and create a new information-delivery system to enable effective use of the surficial geologic information. Geologic map data will be collected by coordinated interagency teams by pooling resources such as drilling rigs, specialized laboratory facilities and geophysical equipment, and expert personnel. The Coalition intends that this program will serve as a model for similar efforts in other regions. Subsequent efforts will require less financial support because many tools and concepts developed in this program can be transferred to other mapping endeavors.

\section{LOCAL ISSUES}

Through cooperation with the widest possible range of stakeholders, each mapping project in the program will identify local resource, hazard, and environmental issues.
For example, there is a pressing need for map information in rural areas to respond to issues such as pesticide bestmanagement practices, source-water assessments, and waste disposal. Project resources will be directed toward gathering information that can be used to support decisionmaking in specific areas of interest to stakeholders.

A Liaison Committee, composed of State and Federal education/outreach project staff, the lead geologist in each project area, and members of the user community and local stakeholders (for example, business community, schools, government agencies, and environmental groups), will be established to assess needs and problems of priority mapping areas and to design map products tailored to local needs. The Liaison Committee will ensure that mapping activities avoid focusing on site-specific environmental or resource problems so as not to compete with private-sector work. However, Coalition members will advise local consultants and provide all requested data to assist workers in the private sector in interpreting their data. Each project team also will propose to meet with local officials. Plans for publishing and distributing map products as well as supporting user applications will be developed concurrently with the mapping activities (fig. 17).

\section{EXISTING DATA}

A wealth of subsurface data, including well logs, waterquality data, remedial investigation and engineering reports, 
and coal, oil, gas, and aggregate mineral test-boring logs, are scattered in the offices of various agencies and private consulting firms. A substantial effort will be made to collect these data and evaluate the quality of the existing subsurface information. An upfront commitment will be made to tie this information to a data base that allows for easy retrieval. The five surveys will collaborate with other State and Federal agencies to develop interrelated and complementary data bases and geologic information delivery systems.

Stratigraphic core and test holes, engineering borings, and water wells with detailed descriptions of geologic materials comprise the highest quality subsurface geologic data. In particular, the extensive sample and geophysical data retrieved from the stratigraphic core holes and test holes make them key stratigraphic control points, which will be used as reference data in the study areas. In some areas, core holes will be completed in localities where scarce data or significant reference sections have been identified outside of detailed study areas.

A parallel effort will be made to identify, obtain, and evaluate economic, demographic and related digital data from other disciplines (such as, soils, water, and biology) and to incorporate the data into the program's data system. These kinds of information can be combined with geologic map products to deliver custom decision-support products.

\section{STATE AND FEDERAL DATA BASES AND A GEOLOGIC INFORMATION DELIVERY SYSTEM}

All map products and their supporting data bases, along with economic and demographic data derived from other sources, must be available to the public in easily readable and retrievable formats. For this reason, the Coalition will develop a geologic information delivery system. It is a decision-support system, not just a GIS. It consists of new and existing relational data bases of geologic and societal data, connected to state-of-the-art software for specialized threedimensional geologic visualizations and analyses, geophysical applications, geographic information systems, cartographic systems, geologic illustrations, and geostatistical studies. The system culminates in mechanisms whereby geologists work closely with the stakeholders in displaying, analyzing, and applying maps and data bases to the solution of societal problems.

The geologic information delivery system will contain coordinated data bases of field data, laboratory results, economic and demographic data, geologic maps, and derivative map products in readily accessible formats. Products will range from paper maps to digital map coverages and threedimensional models, compiled for CD-ROM (compact disc, read-only memory) or Internet distribution according to the needs of the user community. All data will be stored in digital format in renewable data bases that will be dynamic and subject to update and correction as new information

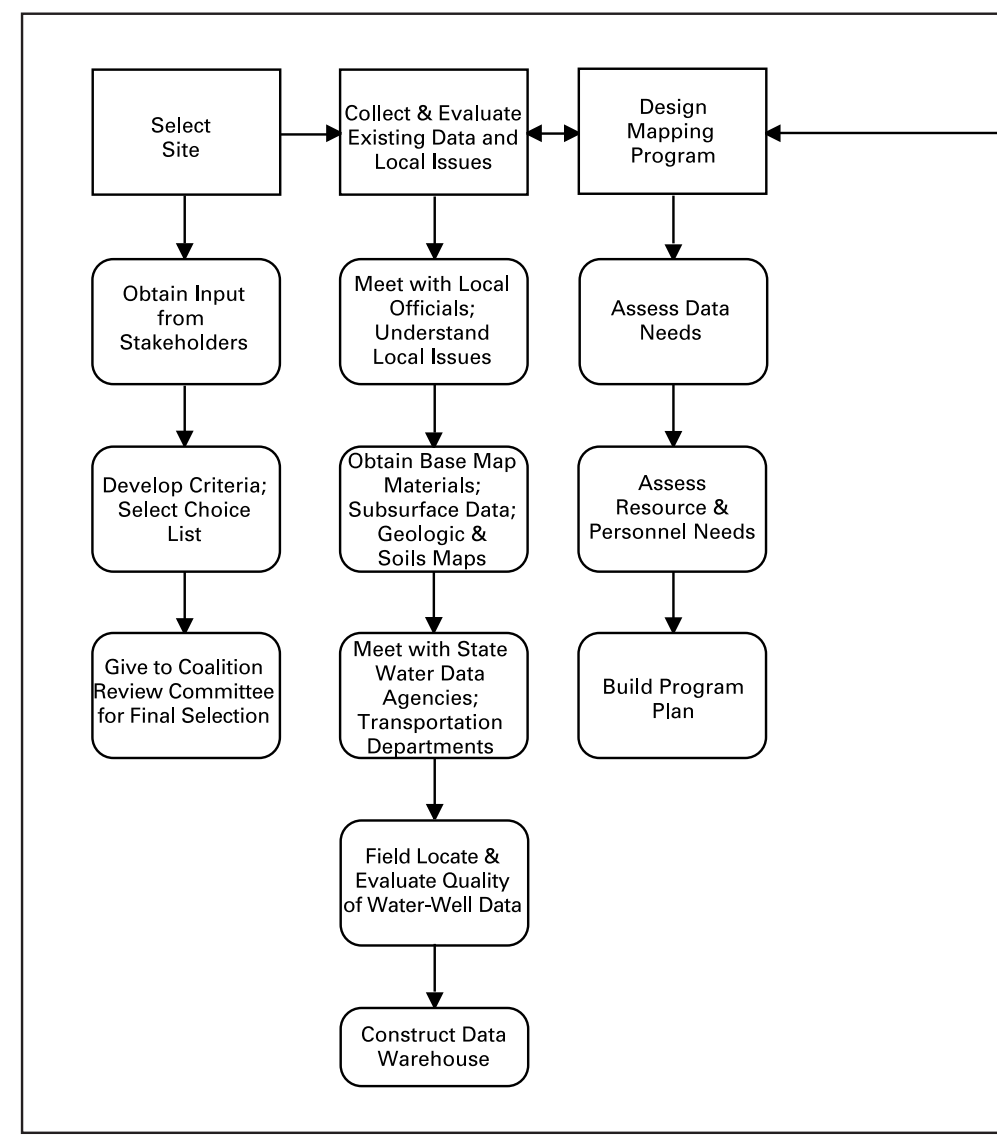

Figure 17. The process of making surficial geologic maps from site selection to enabling the user.

becomes available. Requested information from the data bases will be available in formats that are compatible with multiple platforms and software applications.

Annual public meetings and customer workshops will be conducted to present the results of the mapping in the four States. Feedback from these forums will guide the modification of existing map products and design of future products for improved understanding of the geology and its usefulness for solving societal problems.

\section{CHARACTERIZATION OF SURFICIAL MATERIALS}

The Coalition will develop descriptive, sampling, and analytical protocols, including a comprehensive qualitycontrol protocol, that are appropriate for characterizing the materials in the region. In developing these protocols, the Coalition will also establish a benchmarking activity to evaluate how analyses are conducted elsewhere, and it may contract out certain procedures. It also will develop datainterpolation techniques to integrate data from different 


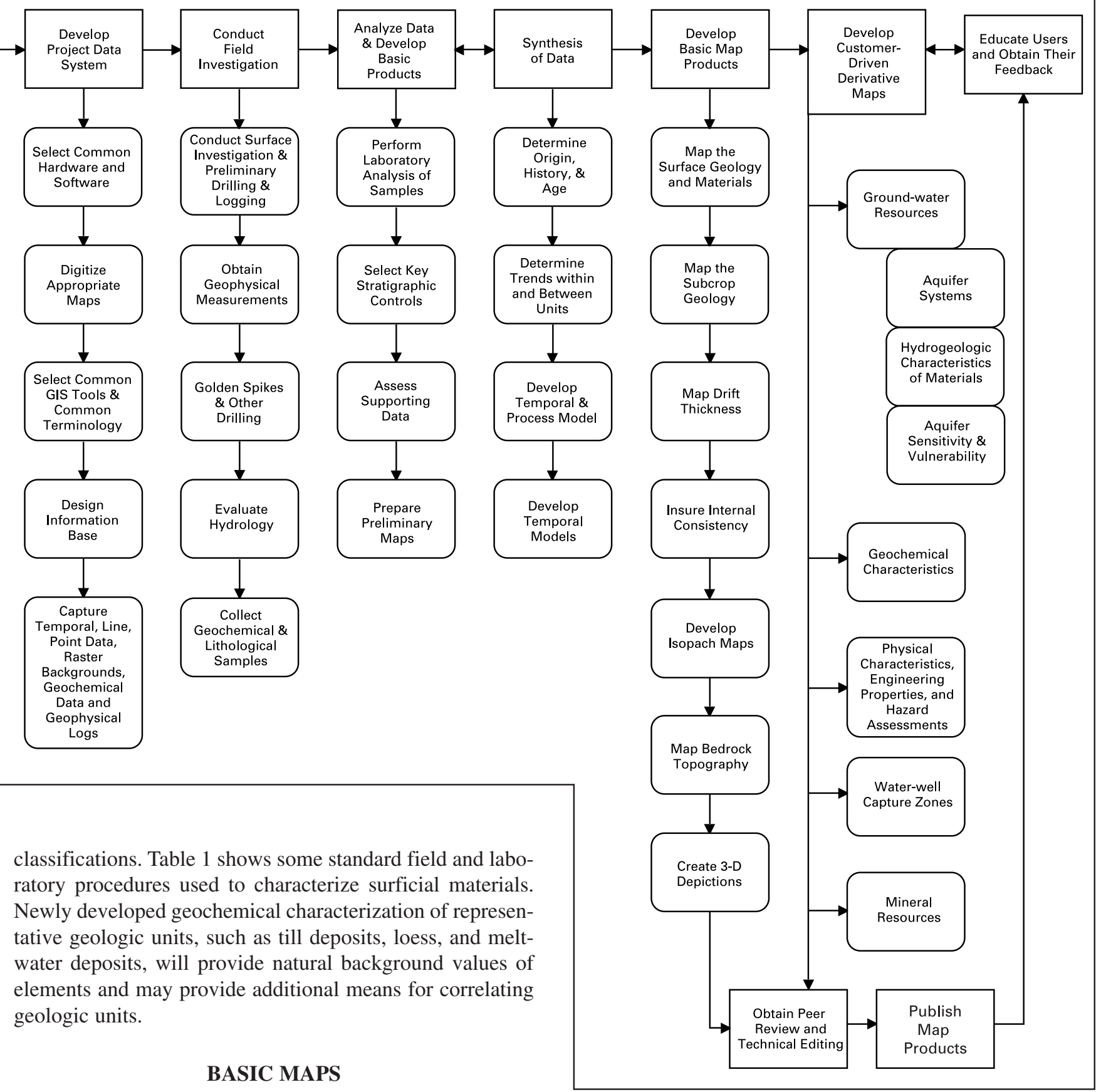

Table 2 shows basic geologic map products that will be produced by the five surveys. The process of making modern, detailed surficial geologic map products that lead to a threedimensional model requires many more steps and techniques than the process of making a traditional map. Figure 17 illustrates the sophistication and complexity of this process. Further, this process is iterative; as discoveries of new geologic complexities are resolved, geologists may update and reinterpret the data. The concepts of dynamic "living" digital data bases and maps are fundamental elements of the Central Great Lakes Geologic Mapping Coalition. 
Table 1. Typical methods used to characterize surficial materials.

\begin{tabular}{|c|c|}
\hline Characteristic & Methods \\
\hline \multicolumn{2}{|r|}{ Lithologic characteristics } \\
\hline Color & Munsell soil-color classification (Munsell Color Company, 1975) \\
\hline Grain size & $\begin{array}{l}\text { Grain-size card showing half-phi sizes, standard sieves, } \\
\text { laser-based particle size determination system, settling tube, } \\
\text { hydrometer, SEM (scanning electron microscope) confirmation. }\end{array}$ \\
\hline Mineralogy & $\begin{array}{l}\text { XRD (X-ray diffraction) clay mineralogy, heavy-mineral separation, carbonate content } \\
\text { (Chittick apparatus), mineral staining, optical methods, thin sections. }\end{array}$ \\
\hline Structure & Stratification, paleocurrent indicators \\
\hline Standard penetration test & Split-barrel sampler, 140 -lb hammer, 30-in. drop, $N$ value (number of blows in 12 in.) \\
\hline Atterberg limits & Multipoint liquid limit, rolled-thread plastic limit \\
\hline Density & Drive cylinder sample, dry density procedure \\
\hline Porosity & $\begin{array}{l}\text { Drive cylinder sample, saturated-dry difference; mercury intrusion porosimetry; thin- } \\
\text { section counts. }\end{array}$ \\
\hline Shear strength & Consolidated, drained direct-shear test \\
\hline Compressive strength & Unconsolidated, undrained, triaxial test \\
\hline \multicolumn{2}{|r|}{ Hydrogeologic characteristic } \\
\hline Permeability & Permeameters, measurements on drive cylinder sample, or recompacted sample \\
\hline \multicolumn{2}{|r|}{ Geochemical characteristics } \\
\hline $\begin{array}{l}\text { Selected element } \\
\text { concentrations. }\end{array}$ & $\begin{array}{l}\text { ICP-AES (inductively coupled plasma-atomic emission spectroscopy) to determine } \\
\text { concentrations of } 40 \text { major elements, minor elements, and trace elements. }\end{array}$ \\
\hline Oxide analysis & $\begin{array}{l}\text { Major rock-forming oxides will be determined by using appropriate ICP-AES or X-ray } \\
\text { fluorescence (wavelength dispersive) techniques. }\end{array}$ \\
\hline \multicolumn{2}{|r|}{ Geophysical characteristics } \\
\hline Natural gamma radiation & Downhole, outcrop, airborne surveys, total gamma and gamma spectral radiation \\
\hline Electromagnetic fields & $\begin{array}{l}\text { EM VLF (electro-magnetic very low frequency), EM-34, square-array DC (direct } \\
\text { current) resistivity; potential fields, time domain EM; ground-penetrating radar } \\
\text { profiles. }\end{array}$ \\
\hline Magnetic susceptibility & Bulk, remanent \\
\hline Physical properties & Seismic reflection and refraction surveys and profiles \\
\hline \multicolumn{2}{|r|}{ Soil characteristics } \\
\hline Parent materials, soil horizons & $\begin{array}{l}\text { Field and laboratory procedures of the U.S. Department of Agriculture, Natural } \\
\text { Resources Conservation Service (formerly Soil Conservation Service). }\end{array}$ \\
\hline
\end{tabular}




\section{REGIONAL SOCIETAL ISSUES REQUIRING EARTH SCIENCE INFORMATION}

The unnumbered yellow pages in the center of the report contain nine short articles: eight discuss regional societal issues requiring earth science information, and one discusses the need for education as part of the mapping program. Each ends with a specific outcome planned for the Central Great Lakes Geologic Mapping Coalition (see p. 34). The articles are listed below:

1. Competition for the Land

2. Water Resources

3. Construction Materials

4. Coastal Erosion

5. Floods

6. Earthquakes

7. Contamination of Land and Water

8. Ecosystem Change

9. Education as Part of the Program 


\section{ARTICLE 1. COMPETITION FOR THE LAND ... POPULATION GROWTH + ECONOMIC GROWTH + 3-D GEOLOGY = SUSTAINABLE DEVELOPMENT}

Population growth and shifting patterns of growth can place considerable stress on an environment if the geologic materials are not compatible with a particular land use. According to the U.S. Department of Commerce, Bureau of the Census (1997), the four-State Coalition region has the following population characteristics:

- A July 1, 1997, population estimate of 38,720,000, about 14.5 percent of the Nation

- 25 cities with populations over 100,000: Chicago, Detroit, Indianapolis, Columbus, and Cleveland are in the Nation's top 25

- 89 counties of the 1,000 fastest growing in the Nation, a 10 percent increase from 1990 to 1997 (IL-14, IN-24, MI-32, OH-19)

- 37 counties that have increased in population by >10,000 from 1990 to 1997 (IL-9, IN-8, MI-10, OH-10)

Urban/suburban buildup in the Coalition States increased by over 1,400,000 acres (about 2,200 square miles) from 1982 to 1992. As of 1992, urban land accounted for 12,432,500 acres (about 19,425 square miles) or about 14 percent of the national total; see table below.

Urban land (acres) for the Coalition States and the United States

[Data from U.S. Department of Agriculture, 1982, 1987, 1992, Natural Resources Inventory]

\begin{tabular}{|l|l|l|l|l|l|l|}
\hline & Illinois & Indiana & Michigan & Ohio & TOTALS & U.S. \\
\hline $\mathbf{1 9 8 2}$ & $2,854,000$ & $1,866,200$ & $3,223,200$ & $3,086,100$ & $\mathbf{1 1 , 0 2 9 , 5 0 0}$ & $78,373,400$ \\
\hline $\mathbf{1 9 8 7}$ & $3,003,000$ & $1,987,400$ & $3,425,300$ & $3,289,700$ & $\mathbf{1 1 , 7 0 5 , 4 0 0}$ & $84,892,600$ \\
\hline $\mathbf{1 9 9 2}$ & $3,094,200$ & $2,094,700$ & $3,685,900$ & $3,557,700$ & $\mathbf{1 2 , 4 3 2 , 5 0 0}$ & $92,352,400$ \\
\hline $\begin{array}{l}\mathbf{1 9 8 2 - 9 2} \\
\text { increase }\end{array}$ & $\mathbf{2 4 0 , 2 0 0}$ & $\mathbf{2 2 8 , 5 0 0}$ & $\mathbf{4 6 2 , 7 0 0}$ & $\mathbf{4 7 1 , 6 0 0}$ & $\mathbf{1 , 4 0 3 , 0 0 0}$ & $\mathbf{1 3 , 9 7 9 , 0 0 0}$ \\
\hline
\end{tabular}

Population growth and shifting population patterns are accompanied by industrial and commercial growth. The four-State Coalition region has had a rich history of industrial development, and it currently has:

- A combined gross State product that is 14.5 percent of the gross national product (National Science Foundation, 1996)

- About 20 percent of the Nation's manufacturing establishments, employees, and value of manufactured products (U.S. Department of Commerce, Bureau of the Census, 1998)

- 91 Fortune 500 companies and 92 Forbes 500 companies (Fortune Magazine, April 24, 1996; and Forbes Magazine, April 20, 1998)

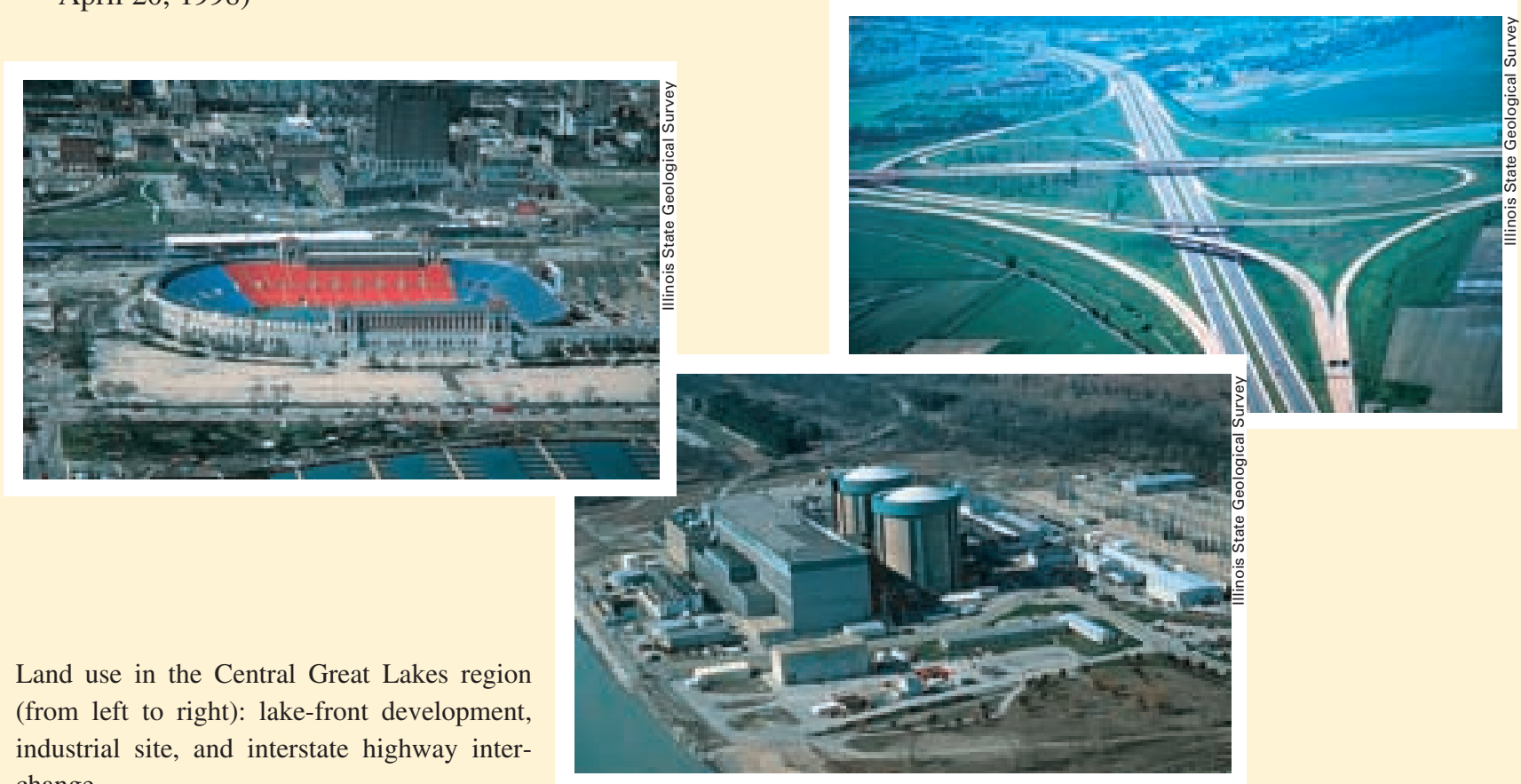
change. 
A detailed, three-dimensional geologic mapping program, focusing on prioritized urban, suburban, and economically expanding areas, can provide planners with information to answer critical questions that will lead them to make wise development decisions:

- Will there be sufficient ground-water supplies to sustain residential subdivisions?

- Should subdivisions rely on private wells and septic systems or should public systems be provided?

- Are the earth materials capable of supplying large industrial ground-water supplies?

- Will heavy pumping of wells have an adverse effect on available ground-water resources?

- Are land areas available that minimize ground-water contamination from a municipal landfill site?

- Are aggregate resources close enough to supply needed low-cost materials for house construction and road building?

- What characteristics of earth materials are most and least conducive to excavation, and where are these materials present?

- What is the redevelopment potential of abandoned industrial lands (brownfields)?

- What is the potential for landsliding, shaking due to earthquake activity, subsidence due to undermining, flooding, erosion, and other natural hazards?

- Can wetlands be effectively restored and maintained?

The four State Geological Surveys and the USGS will work closely with the planning community, industrial and commercial developers, and the public to convey the importance of geology in the land-use decisionmaking process. Sustainable economic development must rely on this information as an incentive to encourage growth in those areas that provide optimum resources and that also lack sensitive settings and hazards which may be costly liabilities in the future.

Clockwise from upper right: field mapping, computer analysis, and derivative map of sand and gravel resources.
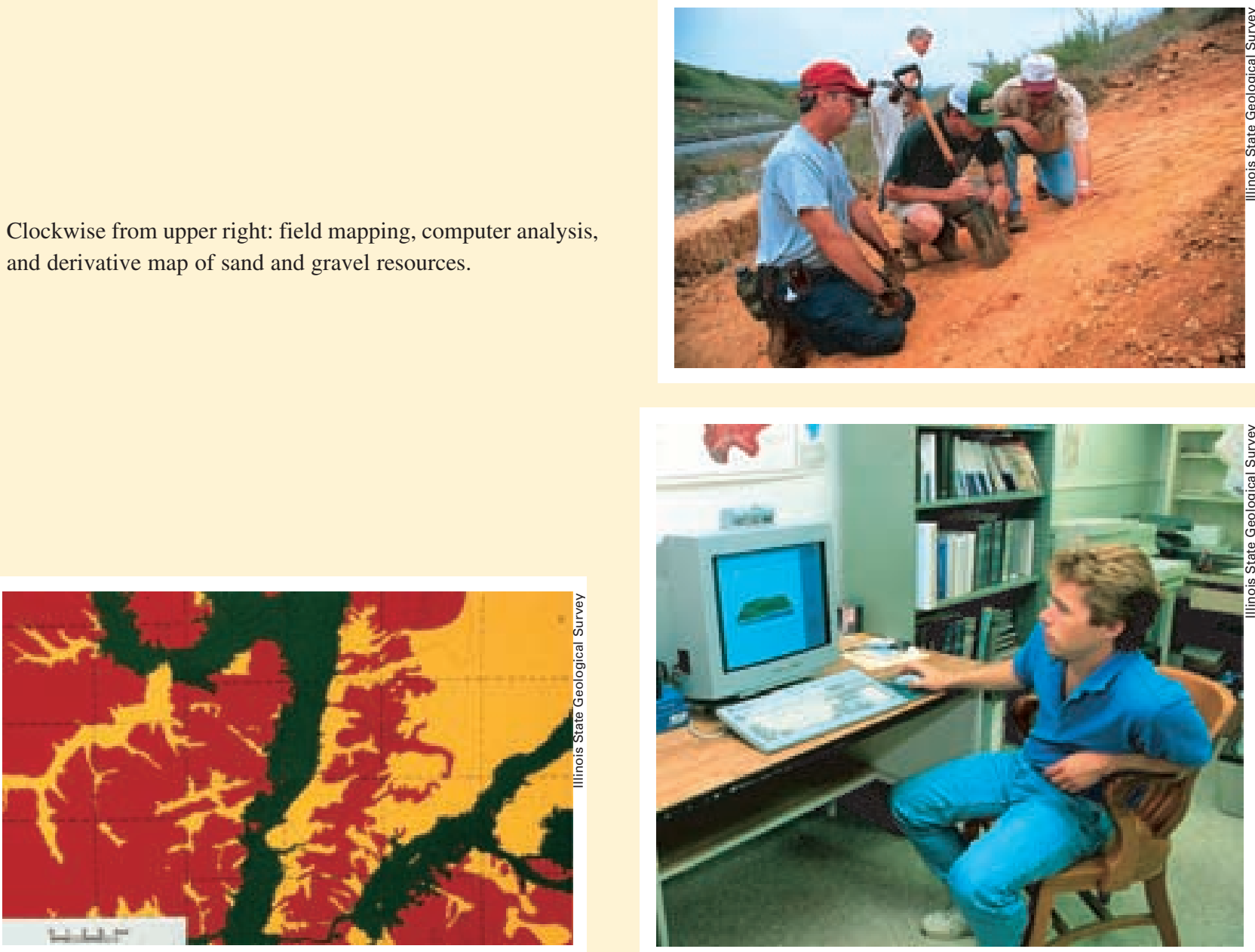

In each project map area, Coalition staff and collaborating partner groups will produce a folio of maps that assess the sustainable capabilities of resources and limiting effects of hazards and environmental changes. These teams will assess the outcomes of resource, environmental, and hazard decisions based on the new, comprehensive data and analyses. 


\section{ARTICLE 2. WATER RESOURCES ... DEPENDENCE ON SHALLOW AQUIFERS AND STREAM AND LAKE WATER}

The three-dimensional mapping of surficial deposits at 1:24,000 scale will delineate the extent of aquifers in highpriority regions of the four States, particularly in high-population areas and areas of rapid population growth. All urban, suburban, and rural residents, industries, and commercial and recreational establishments require water for drinking, for irrigation, or manufacturing. Two examples from Michigan highlight the importance of having detailed three-dimensional geologic information to delineate aquifers.

Example 1.- In 1981, the city of Battle Creek, Michigan, had to shut down wells in the south side of the Verona well field. By 1984, up to 21 of the 30 wells had been shut down (Grannemann and Twenter, 1985). Lack of knowledge of the three-dimensional geometry of the glacial and bedrock geology and hydrogeology delayed understanding of the nature of the problem and design of the remedial action.

Example 2.-The city of Cadillac, Michigan, developed a municipal water well field on the north side of the city in 1960. Clay zones found in the drill cuttings were thought to be extensive and protective of the aquifer from surface activities. The city subsequently developed an industrial park around the well field. Contamination investigations done in the 1980 's discovered that clay did not form a large, continuous layer. The clay had been deposited in a small glacial lake, rather than beneath an extensive ice sheet (Kincare, 1989). By 1990, trichloroethene had been detected in a water sample from one of the city's wells.

According to data compiled by the National Groundwater Association (1997; see graphs below), there are 2,830,778 households served by residential wells in the four-State Coalition, 25,494 public wells, and 7,943 community wells. Community wells are a subset of public wells defined as serving at least 15 connections used by year-round residents or serving at least 25 year-round residents. Nationally, Michigan ranks \#1 in number of household wells $(1,121,075)$, while Ohio, Indiana, and Illinois rank 6th, 9th, and 14th, respectively. Indiana ranks 4th among other States for public supply wells, while Ohio, Michigan, and Illinois rank 6th, 9th, and 11th, respectively. Ohio also ranks 6th for community supply wells.
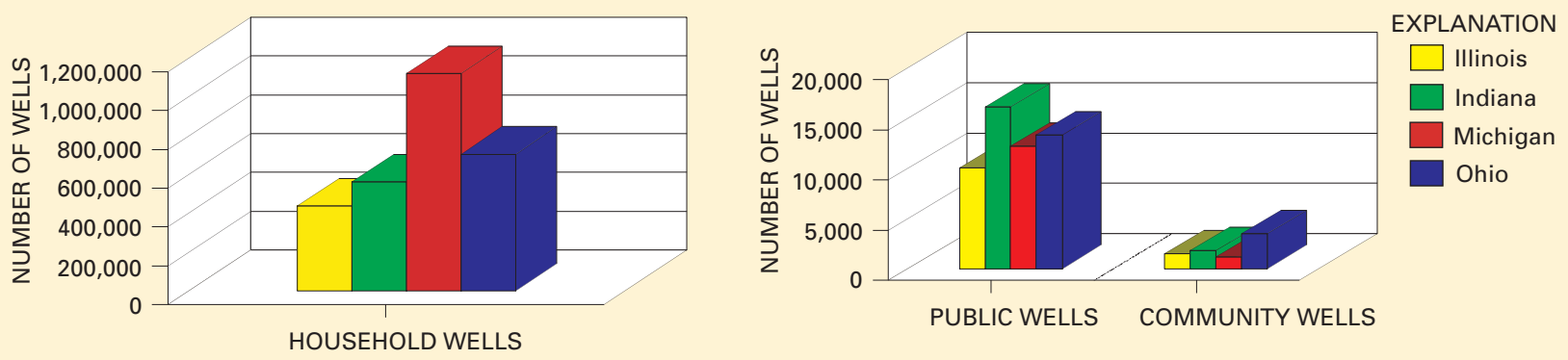

Household wells (left) and public and community wells (right) in Illinois, Indiana, Michigan, and Ohio. From the National Groundwater Association (1997).

Subsurface sources of water need to be better understood; many wells tap aquifers in glacial materials. (see diagram on facing page). State water resource agencies provided the following estimates on surface- and ground-water use:

- In Illinois, surface-water to ground-water use is about 70 percent $/ 30$ percent. Outside of the Chicago metropolitan area, the ratio is about 20/80. Illinois has been issuing permits for well drilling since 1988: 1989/90 had about 9,300 permits issued; however, from 1991 to 1997, the number of wells drilled has been fairly constant, averaging 7,281/year. About 45 percent of the wells are finished in glacial materials.

- In Indiana, about 60-70 percent of the wells are finished in glacial materials.

- In Ohio, at least 50 percent of its wells are finished in glacial materials.

- In Michigan, surface-water to ground-water use is 50 percent/50 percent. Surface-water use is dominated by connections to the Detroit and Grand Rapids distribution systems. About 70 percent of the wells are finished in glacial materials. 


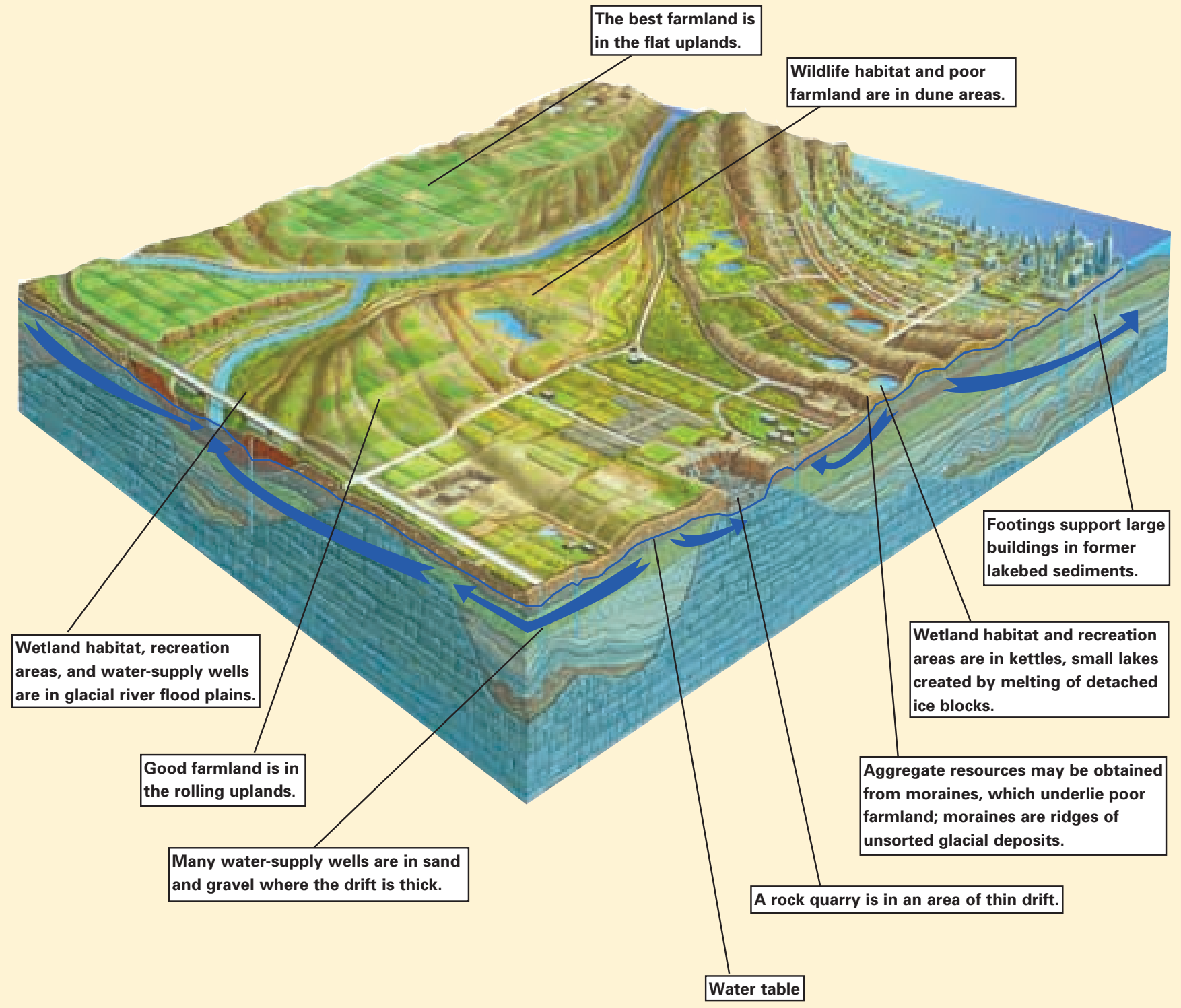

Generalized ground-water flow (arrows) and position of the water table on a three-dimensional geologic model of glacial sediments in the Central Great Lakes States. The geologic model and hydrologic data are used to estimate the infiltration of water into the deposits (recharge), flow of ground water through multiple aquifers and confining layers, exchange of ground water between glacial deposits and bedrock, and eventual discharge of ground water to surface-water bodies. Diagram modified from one by J.M. Evans, USGS. The subsurface layers are easier to see in the version of this diagram on the front cover, which does not include information on the water table.

Each Coalition team, in partnership with water-resources experts, will quantify water use from surficial aquifers and trends in use and water quality. Each team will use new subsurface analyses, including ground-water head measurements, to differentiate individual surficial aquifers and define newly discovered aquifers in the regional aquifer system around each project area. 


\section{ARTICLE 3. CONSTRUCTION MATERIALS ... GLACIAL AND CRUSHED ROCK AGGREGATE RESOURCES \$1.8 BILLION INDUSTRY AND LAND-USE CONFLICTS}

Finding nearby sources of high-quality aggregate is essential for sustained economic development of the four Coalition States. All construction projects, including roadbeds, foundations, masonry, and riprap, require aggregate. Hauling it from distant sources to where it is needed greatly increases costs. For example, delivery costs can double 8-24 miles from the source and triple 40 miles from the source (Hughes and Bradbury, 1989; see upper graph below). Aggregate is derived from sand and gravel associated with glacial deposits, or from bedrock (particularly magnesium-rich dolomite).

The 30-year trend in aggregate production in the Coalition States shows a low period in sand and gravel production from 1980 to 1987 (see lower graph below). Barring this period, which included the 1982 recession, sand and gravel production in the four States has been steady, fluctuating around the 150 million metric ton/year mark. Stone production also was low in the same 1980-87 period, but it has broken away from the flat pre-1980 trend and has been rising ever since.

About 240 million metric tons of crushed stone and 160 million metric tons of sand and gravel currently are produced in the four States per year. The industry has grown from about \$400 million in sales in 1968 to about \$1.8 billion in 1997. An increased demand for aggregate should continue in the future because urban and suburban areas are expanding, and the Federal Government has increased highway spending for road and bridge repair by 30 percent for the next 6 years (U.S. Geological Survey, 1999 [for data after 1971], and U.S. Bureau of Mines, Minerals Yearbook, 1933-71).

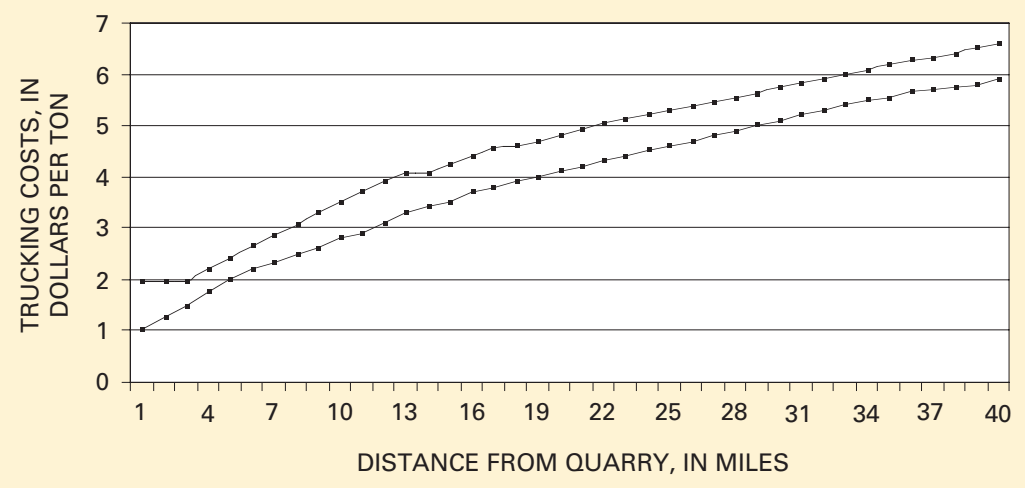

The price of aggregates at the quarry averages $\$ 5.50$ per ton. The two cost curves show trucking costs for inner-city (upper curve) and rural (lower curve) quarry locations in northern Illinois. Modified from Hughes and Bradbury (1989).

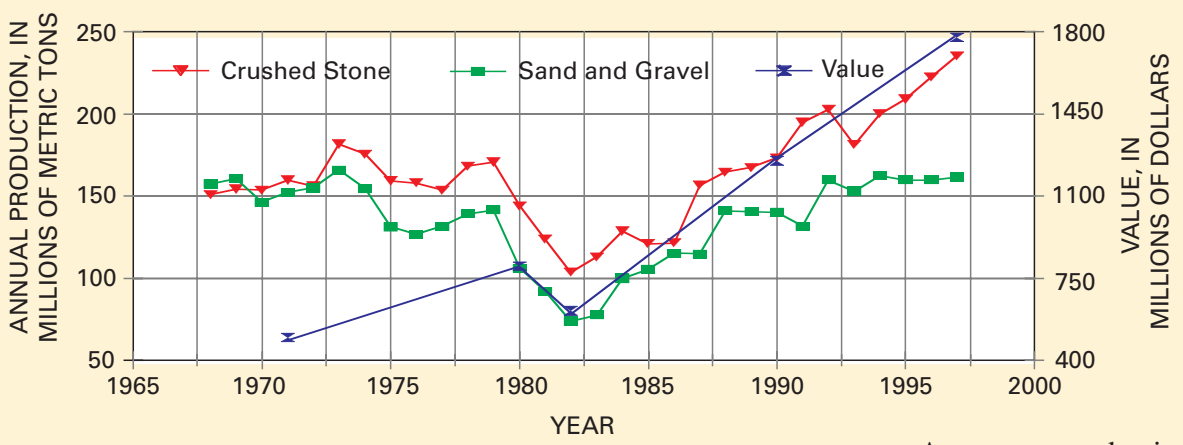

Aggregate production in Illinois, Indiana, Ohio, and Michigan. The amount of aggregates produced and their values are from the U.S. Bureau of Mines' Minerals Yearbook., 1933-71, and the U.S. Geological Survey's minerals information web site at http://minerals.er.usgs.gov/minerals/pubs/commodity 
Rapidly expanding urban areas and the infrastructure that supports them require balancing economic growth with environmental protection. Growth requires plentiful ground-water resources, easily accessible aggregate for construction, and the safe disposal of hazardous and municipal wastes, all of which are dependent on identification of the three-dimensional nature of the glacial geology.

Glacial sand and gravel are an excellent source of aggregate for infrastructure development and all construction projects. Land-use conflicts commonly arise because these materials also provide desirable construction conditions and a shallow ground-water resource for private and municipal wells in residential subdivisions.

The Coalition's three-dimensional mapping program will delineate areas at 1:24,000-scale that have resource potential for aggregate. Critical in the equation for finding nearby high-quality aggregate resources are land-use zoning ordinances, which prevent pits and quarries from locating and expanding. Detailed geologic information must be reviewed carefully by county and municipal planners working with their consultants and Coalition geologists to prevent "resource sterilization" (prevention of a resource from being used) and at the same time promote residential, industrial, and commercial growth.

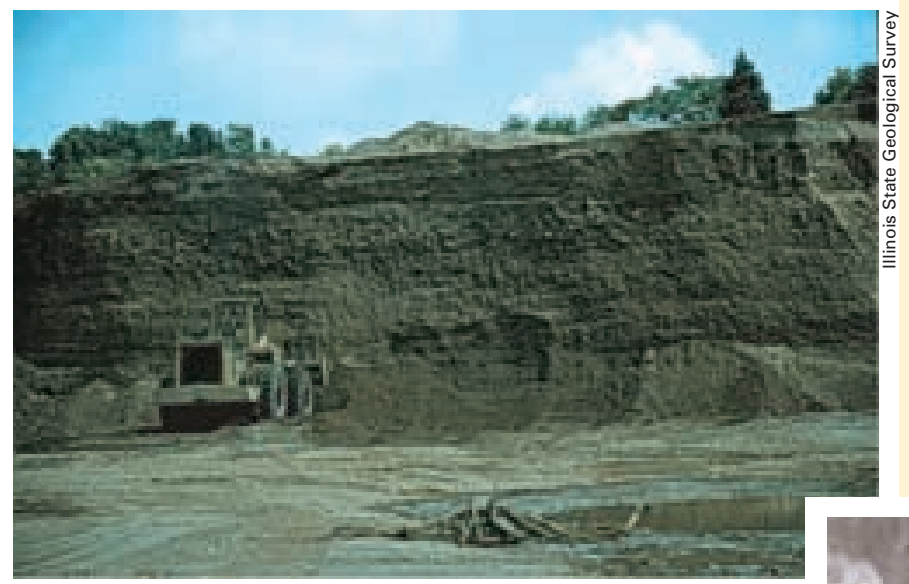

Open-pit mining of glacial sand and gravel deposits for construction aggregate.

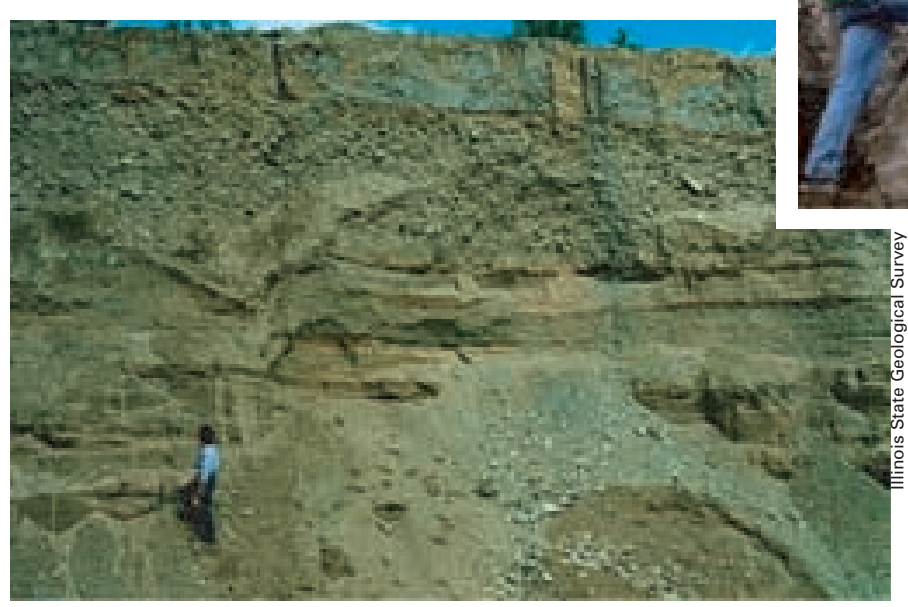

Geologists examining sand (above) and gravel and san (left) for clues about the origin and age of the deposits.

The Coalition staff, in partnership with departments of transportation and industry, will develop techniques to accurately assess the volume and quality of construction sand and gravel aggregate materials, as well as land-use decisions that preempt sustainable aggregate extraction and use. The Coalition will assess regional outcomes of aggregate markets and competing land uses. 


\section{ARTICLE 4. COASTAL EROSION}

The four Coalition States have more than 3,600 miles of shoreline along the Great Lakes (D. Romesburg, Chief Geographers Office, U.S. National Oceanic and Atmospheric Administration, Office of Coast Survey, oral communication, August 20, 1998). Their economy depends on the Great Lakes for home and industrial sites, recreation, shipping, and drinking water. Surficial geologic issues in high-priority areas follow:

- Bluff recession, loss of property, inappropriate development

- Beach erosion and accretion

- Loss of coastal and wetland habitats

- Till downcutting and sand management

- Transport of potential contaminants from land to the lakes through

seeps on bluff faces and ground water discharge into the lakes

- Potential recharge of aquifers from the lakes

Studies on bluff and beach erosion and beach accretion have been conducted for many years because of the immediate impact of these processes on property loss. Studies have concluded that accelerated bluff recession is due to weaknesses of geologic materials in bluffs (for example, sand and gravel through which water seeps and exacerbates erosion), high lake levels and storm events, inadequate shore protection, oversteep slopes, lack of vegetation, excessive water pressures, and lack of sediments traveling with nearshore currents and the resultant absence of protective beaches (Berg and Collinson, 1976). High rates of beach erosion and accretion are attributed mainly to lake-level fluctuations, storm events, and type and adequacy of shoreline protective structures. By working with engineers, Coalition geologists can help design protection measures; by educating local land owners, geologists can suggest means to reduce property losses along reaches of very expensive real estate.

Concern is growing about an aspect of erosion that has not been addressed adequately-erosion of the lake-bottom till ("till downcutting") in the nearshore zone, which is causing deeper water and greater wave energy to occur closer to shore and results in more erosion. Although some investigative work has been conducted in a few places, there has been no regional, comprehensive, and integrated approach. For this latter problem, detailed geologic mapping can identify areas most and least susceptible to erosion, map the existing thicknesses of nearshore sand cover and locations of exposed till or bedrock, predict which shoreline reaches are most/least susceptible to increased erosion from till downcutting, and assist in mitigative procedures. Mapping also can identify offshore sand deposits that could be mined for beach nourishment without creating additional erosion problems.

Another Great Lakes issue that has not been addressed adequately is the interaction between ground water and lake water and how this affects potential contaminant transport from shore to lake (D. Cherkauer, University of WisconsinMilwaukee, oral communication). Specific sub-issues follow:

- Ground-water discharge from onshore glacial deposits to beaches, wetlands, and bluff and dune faces and eventual surface-water flow to a Great Lake have been evaluated only on a local basis

- The extension of glacial aquifers beneath the lakes and their potential to discharge ground water are not well known

- The likely offshore connection between the uppermost bedrock aquifers and the lake is not well known

- Discharging water can enhance release of contaminants from sediments, particularly in harbors and near industrial complexes

- Recharge of aquifers from lake water, most likely from nearshore pumping, has not been adequately addressed

The Coalition's mapping program will provide detailed three-dimensional geologic information needed for modeling ground-water flow, determining recharge/discharge relationships, and evaluating contaminant transport. To date, studies have been limited due to insufficient knowledge of the geology adjacent to the lakes and in the nearshore area. In addition, there is considerable expense incurred for evaluating interactions (for example, by seepage instrumentation). 


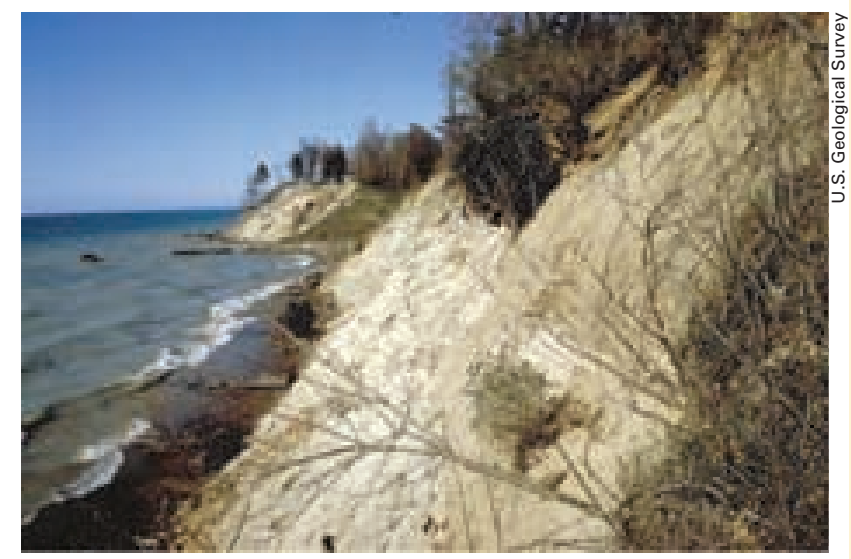

A

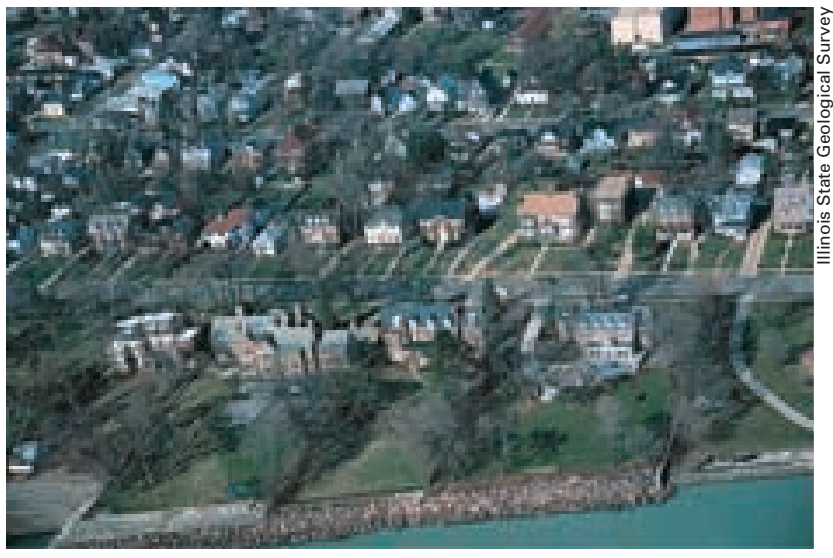

$B$

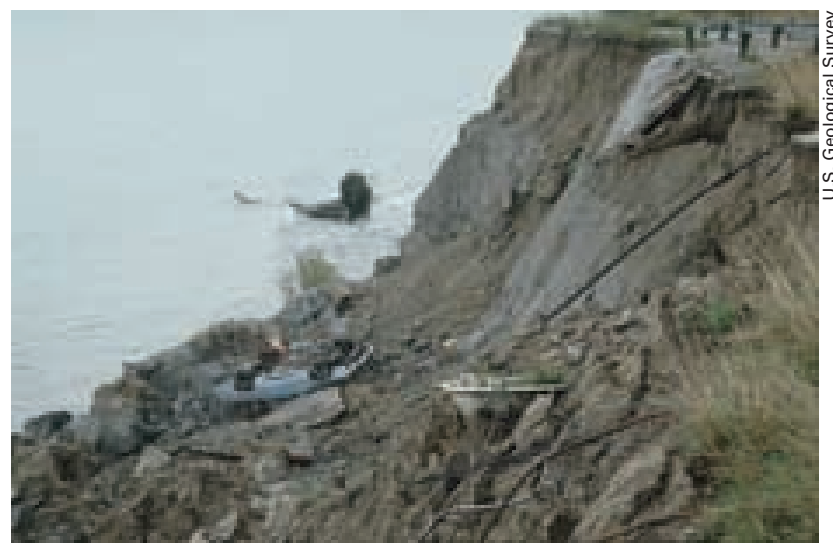

$D$

For Coalition projects in Great Lakes coastal areas, each project team, in partnership with coastal-process experts, will produce maps showing onshore and offshore surficial materials and top of bedrock and will analyze historical shoreline recession or advance. These teams will describe the effects of surficial materials, ground water, and coastal and slope processes on the evolving coastlines. The Coalition will institute plans for rapid response teams for large erosion and flood events. 


\section{ARTICLE 5. FLOODS}

Major flooding along the rivers and streams of the Coalition States has caused disastrous loss of life and property. The Flood of 1993 along the Mississippi River and its tributaries, for example, completely destroyed some towns, put other towns and cities under water, destroyed millions of acres of crops, and rendered some agricultural land nonproductive for many years to come. Even in areas not directly affected by floodwaters, increased rainfall caused the water table to rise to land surface and caused associated ground-water flooding. This was particularly prevalent behind levees and in sandy areas dependent upon irrigation to lower water levels.

A disaster response team composed of Coalition geologists and other researchers will supply critical observations during and immediately following a natural flood disaster. This information is invaluable to relief efforts. A blueprint for such a response action was the reporting of geologic perspectives of the 1993 flooding by the Illinois State Geological Survey, published only 6 months after the event (Chrzastowski and others, 1994). An overview of the flood was provided, followed by discussions on the following:

- Geologic controls on flooding (such as geologic history, landscape evolution, topography, and flood-plain sediments)

- Geologic effects of flooding (including erosion, deposition, recharge and contamination, and ground instability)

- Geologic resources for flood mitigation and damage repair (sand for sandbags and materials for infrastructure repair)

- Geographic information for flood emergency management, recovery, and documentation

In addition to response action to major flood events, the Coalition researchers will also identify the geologic settings most susceptible to damage from floods as a routine part of the three-dimensional mapping program. They will work with local officials and engineers to help them understand the geologic controls on flooding and to help suggest mitigation plans.

Detailed three-dimensional geologic information is needed for the following purposes:

- To locate optimum materials for construction of levees

- To determine the ease of excavation of materials for digging of diversion ditches and to evaluate potential ground-watertable problems while digging

- To evaluate potential upstream and downstream effects of diversion on stream-bank erosion and wetland maintenance
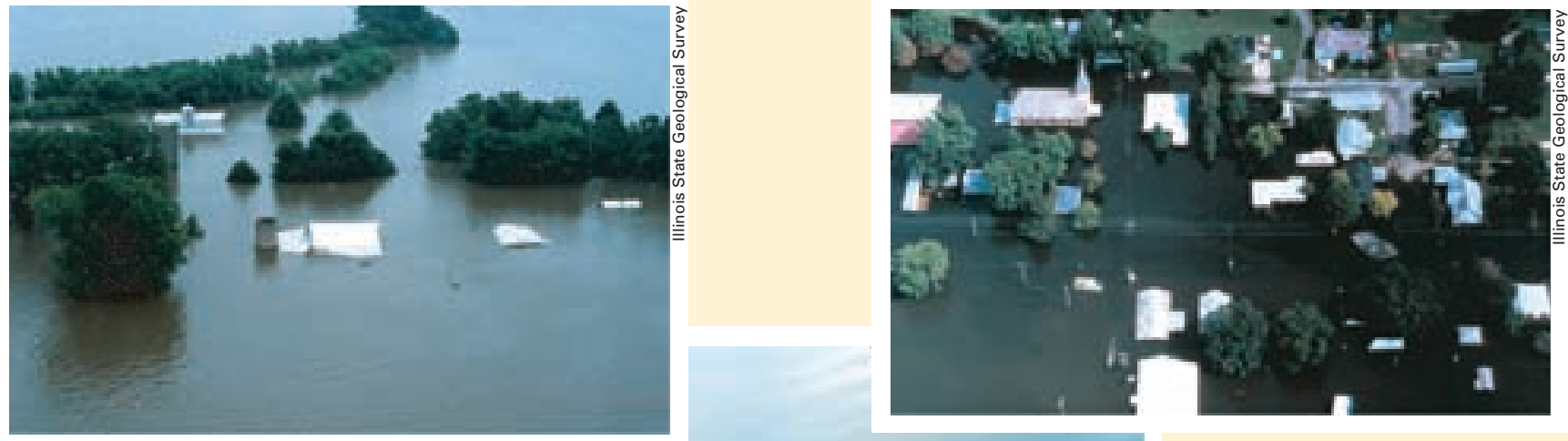

Inundation of the Mississippi River flood plain during the record flood of 1993.

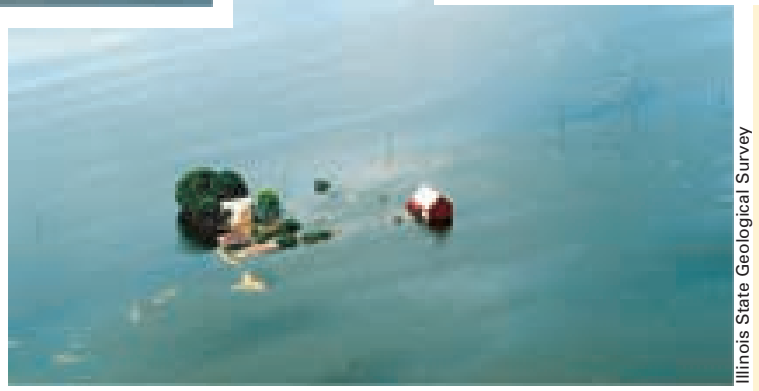

Each Coalition team will define the active geomorphic flood plain and floodable surfaces along major rivers and tributary streams in the study areas. In partnership with surface-water experts, the teams will assess (1) historical flood extents and examples of flood erosion and sedimentation and (2) trends in flood frequency, flood energy, land use, and structures in the flood plain. The Coalition will institute plans for rapid response teams for large flood events. 


\section{ARTICLE 6. EARTHQUAKES}

Three major earthquakes struck the area of New Madrid, southeastern Missouri, along the Mississippi River between December 1811 and February 1812 (Killey and DuMontelle, 1984). Tremors were felt as far away as the East Coast, and nearly 2,000 shocks were strong enough to be felt 200 miles away. Effects of the quakes were 20 -foot ground displacements, large cracks, water spouts and blows of sand erupting from the Earth, landsliding, and the backwards flowing of the Mississippi River. Fortunately, the region was sparsely populated. The recurrence time for another New Madrid event is quite long (4 percent probability in the next 50 years according to the Central United States Earthquake Consortium (CUSEC), 1995). However, scientists estimate that strains have built up along the fault zone since 1912, and shocks of 7.6 on the Richter scale are possible. A 7.6 occurrence or a recurrence of the New Madrid event would result in devastating damage today.

Several large-magnitude 20th-century earthquakes and known sites where liquefaction has occurred in southern Illinois and Indiana imply a major seismic zone that may approach the New Madrid seismic zone in terms of the possibility of large earthquakes (Munson and others, 1997). Also, hundreds of sites containing prehistoric liquefaction features in the Wabash Valley area suggest that repeated earthquakes have occurred in this region over the past 10,000 years. The Earthquake Center at St. Louis University has plotted the location of earthquakes that originated in the Coalition States and elsewhere in the Midcontinent since 1800. Although the New Madrid event and some previous events have been quite severe and there is potential for recurrence, fortunately, earthquakes centered in the Coalition States have been infrequent and relatively mild with small shocks that have caused little or no damage.

In the Coalition States, according to CUSEC (1995), earthquakes have a wide regional effect because glacial, postglacial, and bedrock materials efficiently transmit shock waves over great distances and may have devastating effects many miles from the epicenter of the quake. Shock waves are particularly amplified when they encounter loose water-saturated surficial geologic materials, consisting of windblown silt (loess), silty to sandy river deposits (alluvium), and silty to clayey lake-bed deposits (lacustrine materials). As ground shaking is intensified, materials liquefy (process of liquefaction), resulting in damage to buildings and infrastructure. By contrast, bedrock, tills, and residual weathered soils are less likely to enhance shaking or liquefy.

The Coalition program will identify those deposits that are most and least susceptible to ground shaking and liquefaction. The approach to map deposits in three dimensions is congruent with the Federal Emergency Management Agency (FEMA) recommendation of using average shear wave velocity (speed at which shock waves pass through materials) from the upper 100 feet of materials to estimate potential damage (FEMA, 1995; Su and Bauer, 1998). Once materials are mapped in three dimensions, it will be essential to do the following:

- Measure the shear-wave velocity of the surficial materials

- Estimate the potential for soft sediments to amplify ground motion

- Evaluate the liquefaction potential for materials

Earthquake hazard potential maps can be made for each of the quadrangles and regions within high-priority mapping areas directly from the three-dimensional information. The highest potential for earthquake damage is in the southern parts of Illinois and Indiana and the western and northeastern parts of Ohio. Particularly important will be portrayal of deposits most susceptible to shaking and liquefaction in relation to oil and gas pipelines, refineries, and petrochemical plants (all fire hazards), as well as roads, bridges, railroads, fossil fuel and nuclear power stations, electrical power transmission lines, hospitals, fire stations, schools, waste-disposal and handling facilities, and large industrial complexes.

Each Coalition team, in partnership with seismic experts, will determine the extent and geotechnical characteristics of earth materials that are susceptible to seismically induced liquefaction or landslides. These teams will assess seismicity risks to geologic units or land uses in areas of historical or prehistoric earthquakes. 


\section{ARTICLE 7. CONTAMINATION OF LAND AND WATER}

A major benefit of three-dimensional geologic mapping in the Coalition States is providing geologic context for investigations at specific sites by environmental regulatory agencies and consultants. Mapping provides the following:

- Insight for evaluating the continuity of aquifers and non-aquifers; this is important to assess potential contaminant migration from onsite to offsite locations

- A regional understanding of the degree of natural protection afforded to aquifers by overlying materials; this is important to assess the potential for a contaminant introduced at land surface to reach an aquifer

- Knowledge of properties of geologic materials; this is important because many geologic properties (for example, grain size, geochemistry) evaluated during a routine mapping program are surrogates for estimating hydrologic and contaminant-transport properties

Having geologic context for site-specific investigations (including safe remediation of contaminated sites), in turn, commonly leads to greater predictability of encountering expected materials during site characterizations, reduces the time it takes for characterization, accelerates the permitting process for a number of activities, and decreases characterization and monitoring costs. For example, fewer test borings or fewer monitoring wells may be required because the three-dimensional geology of the area around the site is well known and does not require futher investigation.

The mapping program also provides a screening tool to assist regulators in assessing existing sites and determining whether they pose an immediate environmental threat. CERCLIS, NPL, RCRIS, and Toxics Release sites (U.S. Environmental Protection Agency [USEPA], 1999) all pose environmental threats when located in sensitive geologic settings (for example, aquifer materials at or near the surface). Site types are defined below, and their distribution in the Coalition States is shown in the table and graphs below.

CERCLIS is the official repository for Superfund data supporting the Comprehensive Environmental Response, Compensation, and Liability Act (CERCLA). It contains information on hazardous waste sites from 1983 to the present. This listing shows 1,092 CERCLIS sites in the four-State Coalition area, with Illinois having almost 400. National Priority List (NPL) sites pose the most serious threat to the environment and are a subcategory of CERCLIS. The Coalition area contains 181 NPL sites, with Michigan having the most (71) (K. Kimbrough, USEPA, oral communication, 1998).

The Resource Conservation and Recovery Information System (RCRIS) lists hazardous waste sites as required by the Resource Conservation and Recovery Act (RCRA), including all handlers of hazardous wastes and all types of generators (for example, containment building storage, incinerators, kilns, geologic repository, and tank storage). This list shows 71, 663 sites in the Coalition area, with Illinois having the most $(23,782)$.

The Toxics Release Inventory (TRI) tabulates air emissions, surface-water discharges, releases to land, underground injections, and transfers to offsite locations. The TRI shows 5,987 sites in the Coalition States where toxics have been released, with Ohio having the most $(2,107)$.

Number of CERCLIS, NPL, RCRIS, and Toxics Release sites in the four-State Coalition area and rank of each State among all States in parentheses.

[Data from USEPA (1999)]

\begin{tabular}{|l|l|l|l|l|l|}
\hline & Illinois & Indiana & Michigan & Ohio & TOTALS \\
\hline CERCLIS Sites & $394(9)$ & $195(19)$ & $242(13)$ & $261(11)$ & 1,092 \\
\hline NPL Sites & $43(9)$ & $30(13)$ & $71(5)$ & $37(11)$ & 181 \\
\hline RCRIS Sites & $23,782(4)$ & $9,594(11)$ & $19,142(9)$ & $19,145(8)$ & 71,663 \\
\hline Toxics Release Sites & $1,673(5)$ & $1,123(11)$ & $1,084(12)$ & $2,107(2)$ & 5,987 \\
\hline
\end{tabular}
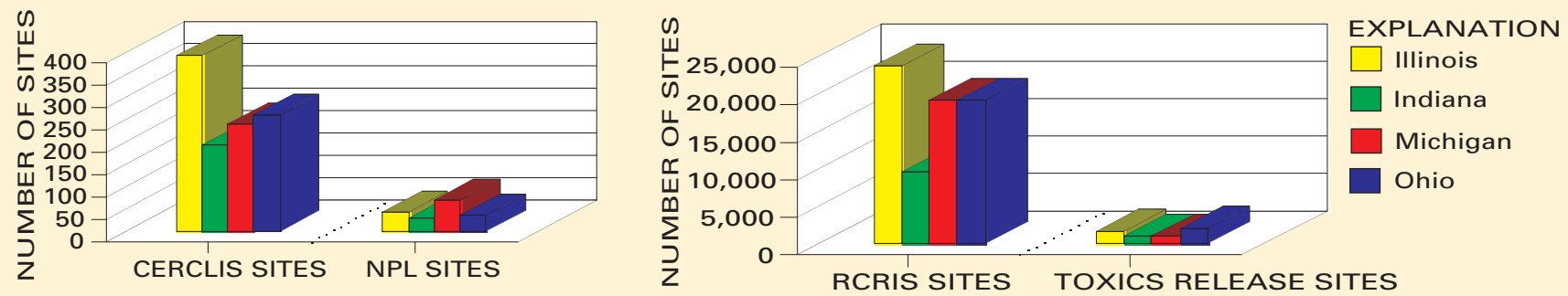

Number of CERCLIS, NPL, RCRIS, and Toxics Release sites in the four-State Coalition area. Data from USEPA (1999). 
Finally, the USEPA is committed to protecting the Nation's ground water. Two recent amendments to the Safe Drinking Water Act (SDWA) - the Source Water Assessment Program (SWAP) and the Ground-Water Rule (GWR, formally the Ground-Water Disinfection Rule)—require that source areas for water be delineated, contaminants be inventoried, and susceptibility/vulnerability analyses be performed (Illinois EPA, 1998, and International Consultants, Inc., 1998).

Susceptibility/vulnerability analyses require as detailed as possible depictions of the three-dimensional geology. Currently, this primarily is accomplished by using available well-log data. The Coalition's three-dimensional mapping program, which will delineate aquifers in detail and provide associated comprehensive data bases, will allow:

- The USEPA and State environmental regulatory agencies to assess in a meaningful manner aquifer vulnerability and to protect water supplies in high-priority areas

- Regulatory agencies, responsible local governments, and their consultants to model ground water within source areas, including determining ground-water time-of-travel for bacteria, viruses, and organic/inorganic chemicals

- State regulatory agencies to understand and assess ground-water and surface-water interactions and potential contaminant flow between ground water and surface water at a watershed level; also help delineate the zone of ground-water contribution and area of surface-water contribution to a public water supply via "conjunctive delineation" under the Source Water Assessment Program

- Non-community public water-supply systems to help determine if their systems are located in sensitive hydrogeologic settings, are vulnerable to contaminant sources, and require costly disinfection under the Ground-Water Rule.

The importance of geology for determining the vulnerability of wells recently has been summarized by the Illinois EPA (1998), which reported that "19\% of the community water supply wells in the state have been impacted by volatile organic chemicals, pesticides, and/or nitrates. The ratio of chemical detection in unconfined versus confined aquifers is 3:1. Of the community wells using unconfined aquifers, $35.5 \%$ already have been impacted by one or more of the three contaminant groups, indicating that natural geologic protection is indeed an important factor in groundwater protection in Illinois."

Improper siting of municipal and hazardous-waste landfills poses a serious threat to ground water. Percolating rainwater that flows through the waste picks up harmful substances, creating a leachate, which can contaminate ground-water resources.

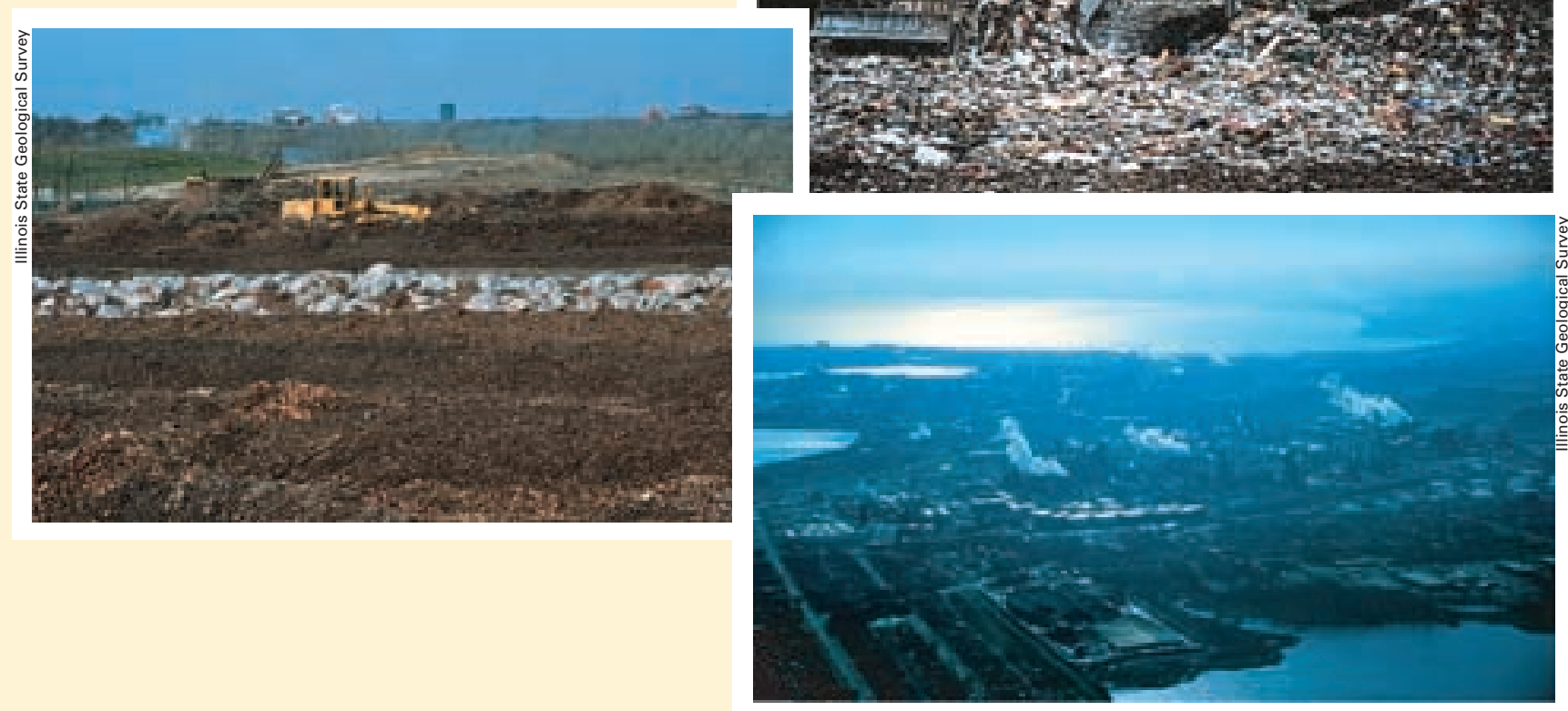

In each project area, Coalition staff will establish the natural background geochemical characteristics of surficial geologic units. In partnership with water-resources experts, project teams will compare these with geochemical trends of ground water, especially in areas containing known pollution sites. Sensitivity of surficial aquifers and other lands to contamination by historical or existing land use will be assessed. 


\section{ARTICLE 8. ECOSYSTEM CHANGE}

Modern geologic maps and knowledge of surficial sediments and the Earth-surface processes that act on them are basic physical-system elements of ecosystem and biodiversity studies. Major issues include the following:

- Preservation and restoration of wetland habitat

- Preservation of commercial fisheries and timber

- Preservation of prime recreational areas

First, surficial materials are the ultimate source of most nutrients in food chains (Lane and Rupert, 1996). Weathering breaks down materials into soils where nutrients are formed, and erosion and transportation of materials allow nutrients to be available to the biosphere. Some of the most productive soils in the world occur where windblown silt (loess) is at land surface. These deposits have a high moisture-holding capacity due to their silt content and are rich in potassium, calcium, and magnesium, all of which are essential for plant growth. In contrast, many soils derived from weathered bedrock are acidic and nonproductive. Second, geologic deposits on various landforms provide direct habitat for fauna (Illinois Department of Natural Resources, 1996). For example, burrowing and subsurface-dwelling insects and mammals and rocknesting birds rely on specific geologic materials and settings. Bottom-dwelling aquatic life depends on specific substrate conditions controlled by the geology. Ground-water seeps and springs often provide local habitats, many with unique temperatures and water chemistry. When the geology, topography, and ground-water hydrology are fully integrated and understood, areas where critical habitats for rare and endangered species are likely to occur can be predicted and possible impacts of proposed management options can be determined.

Both the presettlement ecology and present-day use of the land are influenced by variations in topography and surficial geology. For example, Native American villages typically were located in river valleys where water was easily accessible and flood-plain sediments provided productive soils. Many of today's small towns were built on moraines to avoid flooding. The largest cities grew because of ready access to a surface-water body or a plentiful ground-water resource as a water supply.

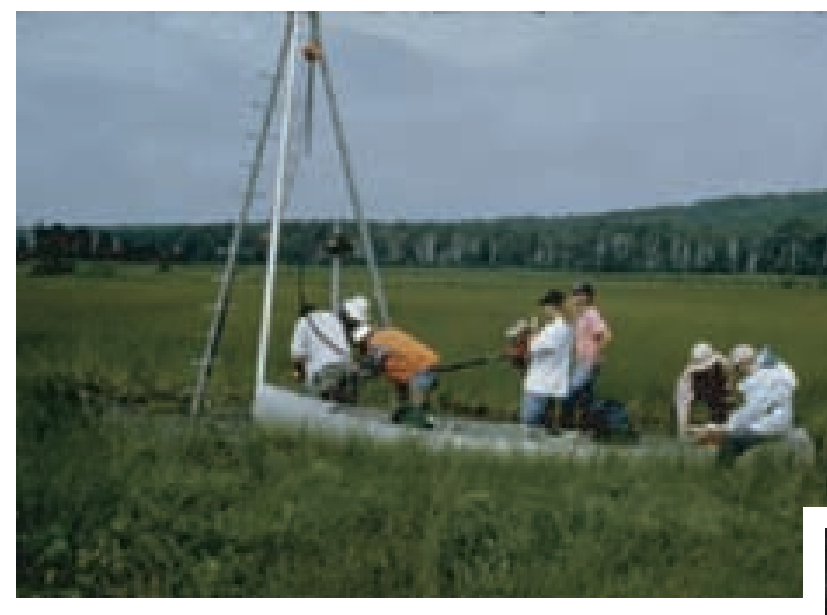

Sampling geologic materials that underlie a coastal Great Lakes wetland habitat.

Open-water wetland between windblown dunes and ancient beach ridges, Indiana Dunes.

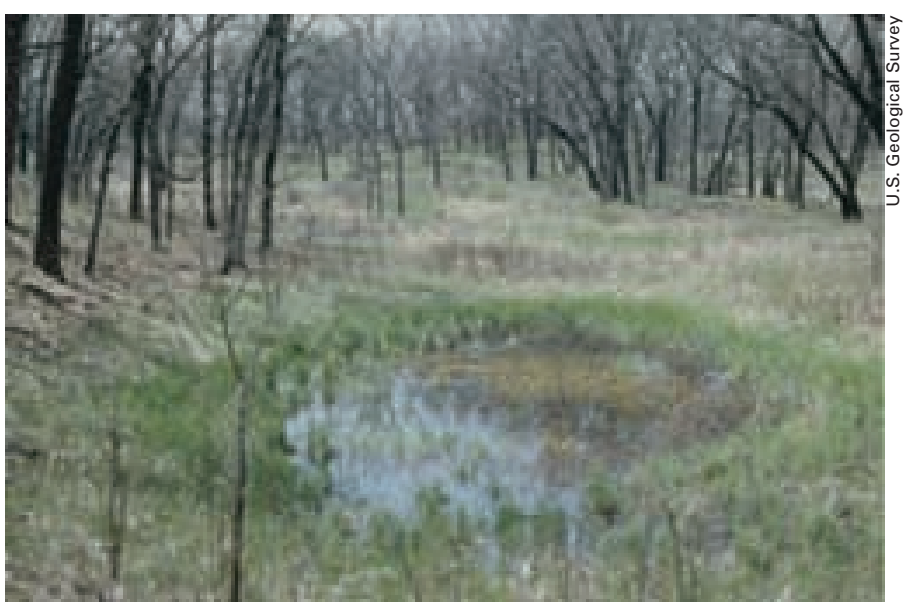

In each study area, Coalition teams, in partnership with biologists and hydrologists, will include analyses of the sensitive relationship between ground-water and surface-water interactions and the potential impacts of various land uses surrounding ecologically sensitive areas to provide decisionmakers with a better understanding of the physical ecosystem. 


\section{ARTICLE 9. EDUCATION AS PART OF THE PROGRAM}

Educating teachers on the benefits of geologic mapping for solving societal issues is a goal of the program and is key to passing down knowledge to students, thereby increasing their appreciation for the importance of geology. Also important is training of existing and new staff at the geological surveys, which ensures long-term continuity of expertise for describing and evaluating geologic materials, and communicating findings to the lay public. Several examples of current education programs by the surveys that will be bolstered by the Coalition program are described below:

SURFSCHOOL.-The USGS recognizes the lack of geologists having experience in surficial and glacial geology. For example, the current staff and their skills of the Eastern Earth Surface Processes Team cannot adequately respond to the Coalition program. Therefore, training is required to expand present geologic mapping skills to surficial geology. In 1997, the USGS developed a workshop known as "SURFSCHOOL" to train USGS and State Survey scientists in field techniques and synthesis of surficial geologic data. Participants learn to confidently and accurately interpret and map surficial geologic materials in order to produce comprehensive surficial geologic maps that characterize the three-dimensional distribution of materials in a stratigraphic framework.

The 1997 SURFSCHOOL reviewed the geologic and engineering characteristics of surficial materials and numerous examples of sedimentation models of glacial, coastal, and river deposits. A team-mapping exercise in Berrien County, Michigan, produced a new surficial geologic map of part of the county. The team discovered that end moraines in the area are composed largely of sorted and stratified meltwater deposits and are capable of supplying aggregate and shallow groundwater resources. These results and planned subsurface data collection as part of the Coalition program will require major revision of older glacial and hydrogeologic maps.

Till workshop.-Also in 1997 the Ohio Division of Geological Survey cosponsored a workshop on hydrogeologic characterization of till deposits for State agencies regulating land and water resources and personnel from private consulting firms. The workshop featured a series of permeameter experiments at a large excavation into the local silty till. These experiments demonstrated the effects of joints (cracks) in the till, which transmitted water as much as three orders of magnitude faster than the undisturbed till deposits. Such first-hand knowledge of these characteristics presented in a friendly, curiosity-driven atmosphere ensures that State and Federal regulators and other interested parties will include these considerations in issues involving landfill siting, toxic-waste siting, environmental cleanup, and future land-use decisions.

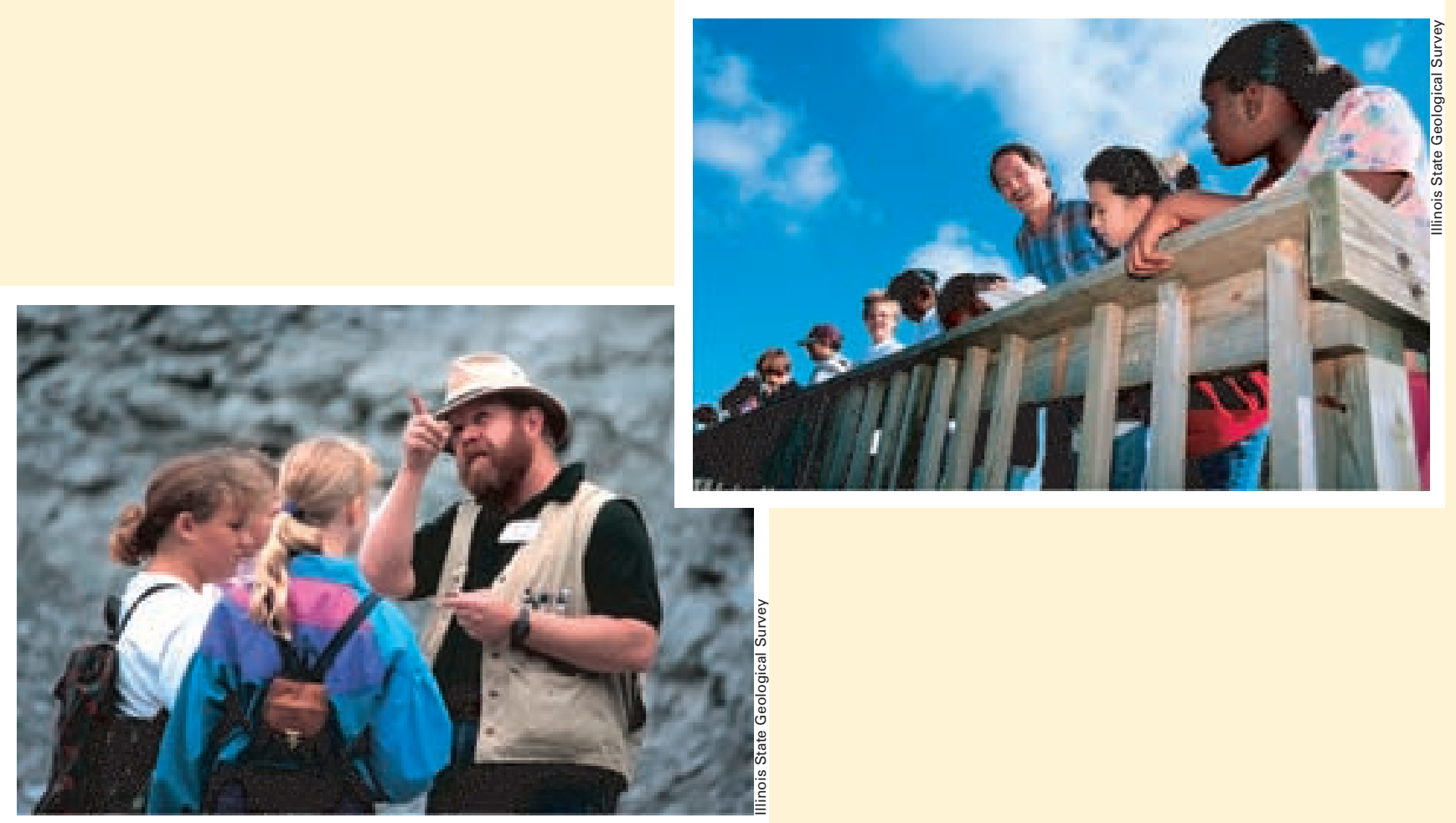


Teachers' workshops on Ohio's mineral industries.-The Ohio Division of Geological Survey and the University of Akron are conducting two annual teachers' workshops entitled "Ohio's Mineral Industries and the Environment." Their purpose is to familiarize teachers with Ohio geology, the importance of Ohio's mineral industries, and the compatibility of today's mining with environmental protection. Most of the teachers arrive unaware that many mineral resources are produced in the State, how these mineral commodities are used daily, or how important these mineral resources are to the economy of the State. The workshops show teachers that mining, reclamation, and environmentally sound subsequent land use represent the modern industry standard. Practical information is conveyed to teachers through professional presentations on the economics, regulations, and uses of Ohio's mineral resources. Teachers are shown how geologic maps illustrate resource origin and extent, and how they can be used to support resource-use decisions. Field trips to mining operations provide experience with the mechanics, economics, and environmental concerns associated with mining specific mineral commodities. Contributions from various trade associations and geological and mining-oriented organizations pay for field-trip expenses and educational materials.

The overwhelming interest, enthusiasm, and positive comments expressed by workshop participants indicate that the effort is successful in creating a positive image for Ohio's mining industry. More importantly, these teachers will show young people that a balance exists between mineral-resource need and environmental concerns. Because these teachers are educated, more of tomorrow's decisionmakers will be better prepared to deal with future land- and water-resource issues.

Teachers' workshops on geology.-The Illinois State Geological Survey conducted seven 2-day geology workshops throughout Illinois for K-12 teachers during 1997-98. The purpose of the workshops was to give the teachers a better background in geology so that they could teach more proficiently to the new Illinois Learning Standards for science. The workshops were part of a program called "Near and Far Sciences for Illinois," which was initiated and partially funded by the Illinois State Board of Education. Over 160 teachers from throughout the State participated in the program, earning graduate credit. Workshops contained a mixture of lectures, hands-on activities and demonstrations, small-group discussions, and a full-day field trip to local areas of geologic interest. A broad spectrum of topics was covered, including some basic principles of geology, geologic history, mineral and water resources, earth hazards, and geology and society. At least three Survey geologists conducted each workshop, exposing teachers to a variety of teaching styles and expertise. Several teachers participated in job-shadowing experiences. Virtual field trips to sites throughout the State are being planned.

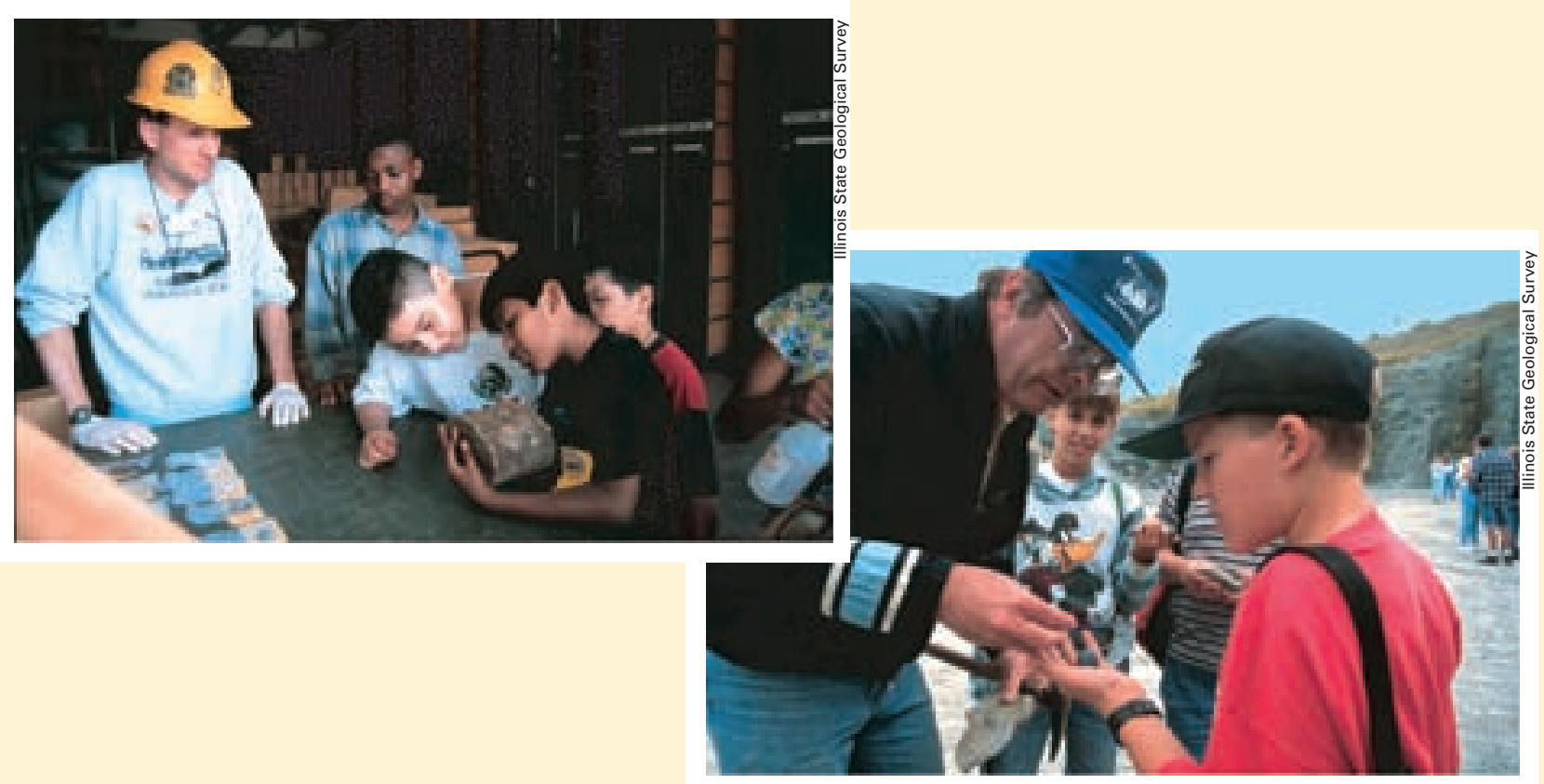

In training programs and public workshops, each Coalition team will educate partner groups in the use of software and analytic techniques. Program geologic and support staff will be trained in new technologies and in cooperating with user groups. 
Table 2. Basic geologic maps and map products to be produced by the Central Great Lakes Geologic Mapping Coalition.

\begin{tabular}{|c|c|c|c|}
\hline Map & Information shown & Classifications and concepts & Map uses \\
\hline $\begin{array}{l}\text { Traditional glacial } \\
\text { geologic map } \\
\text { (includes periglacial } \\
\text { and proglacial } \\
\text { deposits). }\end{array}$ & $\begin{array}{l}\text { Traditional map units at } \\
\text { land surface based on } \\
\text { lithologic characteristics, } \\
\text { genesis, and age within the } \\
\text { regional stratigraphic } \\
\text { framework. }\end{array}$ & $\begin{array}{l}\text { Lithologic characteristics, } \\
\text { depositional models, genesis } \\
\text { of deposits, geologic history, } \\
\text { and isotopic ages of deposits; } \\
\text { lithostratigraphic } \\
\text { classification. }\end{array}$ & $\begin{array}{l}\text { Establishes local stratigraphic } \\
\text { framework of Earth materials } \\
\text { at land surface; shows the } \\
\text { distribution of geologic } \\
\text { materials at land surface for } \\
\text { education, agriculture, } \\
\text { engineering/environmental } \\
\text { studies, and real estate } \\
\text { assessments. }\end{array}$ \\
\hline
\end{tabular}

\begin{tabular}{ll}
\hline Surficial materials & Materials map units at land \\
map. & surface based on grain size, \\
& sedimentary features, \\
& geotechnical classifications, \\
& and landforms.
\end{tabular}

Classifies the materials in geologic, engineering, soils, and hydrogeologic systems.
Provides data for technical assessments of surficial resources, hazards (landslides, liquefaction potential), and engineering conditions.

\begin{tabular}{|c|c|c|c|}
\hline $\begin{array}{l}\text { Bedrock-surface } \\
\text { topography map. }\end{array}$ & $\begin{array}{l}\text { Altitude of the bedrock } \\
\text { surface; may include } \\
\text { distribution of general } \\
\text { bedrock types and analysis } \\
\text { of lithologic/structural } \\
\text { features or buried river } \\
\text { valleys. }\end{array}$ & $\begin{array}{l}\text { Altitudes shown by contour } \\
\text { lines; control points shown by } \\
\text { symbols; shows valleys and } \\
\text { ridges; forms the lowermost } \\
\text { limit for mapping of surficial } \\
\text { materials. }\end{array}$ & $\begin{array}{l}\text { Delineates the base of the } \\
\text { lowermost drift aquifers in } \\
\text { bedrock valleys; identifies } \\
\text { sites of potential hydrologic } \\
\text { communication between drift } \\
\text { and bedrock aquifers. }\end{array}$ \\
\hline Drift thickness map & $\begin{array}{l}\text { Total thickness of surficial } \\
\text { deposits (mostly glacial } \\
\text { drift). }\end{array}$ & $\begin{array}{l}\text { Thickness shown by isopach } \\
\text { contour lines. }\end{array}$ & $\begin{array}{l}\text { Shows overburden thickness } \\
\text { for near-surface mineral- } \\
\text { resource extraction and } \\
\text { construction; shows areas } \\
\text { where aquifers may occur. }\end{array}$ \\
\hline $\begin{array}{l}\text { Surface-elevation } \\
\text { (subcrop) maps and } \\
\text { cross sections. }\end{array}$ & $\begin{array}{l}\text { Extent and altitude of the } \\
\text { top and bottom surfaces of } \\
\text { geologic units; subsurface } \\
\text { stratigraphy of geologic } \\
\text { units. }\end{array}$ & $\begin{array}{l}\text { Extent of units shown by } \\
\text { contact lines; altitudes shown } \\
\text { by contour lines; control } \\
\text { points shown by symbols. }\end{array}$ & $\begin{array}{l}\text { Depicts surfaces of geologic } \\
\text { units that are defined by data } \\
\text { and conceptual geologic } \\
\text { models; defines components } \\
\text { of three-dimensional maps } \\
\text { and ground-water models. }\end{array}$ \\
\hline $\begin{array}{l}\text { Unit thickness } \\
\text { (isopach) maps. }\end{array}$ & $\begin{array}{l}\text { Extent and thickness of } \\
\text { geologic units. }\end{array}$ & $\begin{array}{l}\text { Extent of units shown by } \\
\text { contact lines; thickness shown } \\
\text { by isopach contour lines; } \\
\text { control points shown by } \\
\text { symbols. }\end{array}$ & $\begin{array}{l}\text { Defines components of three- } \\
\text { dimensional maps and } \\
\text { ground-water models. Shows } \\
\text { aquifer and confining-bed } \\
\text { thicknesses and thickness of } \\
\text { aggregate. }\end{array}$ \\
\hline $\begin{array}{l}\text { Three-dimensional } \\
\text { surficial geologic } \\
\text { models. }\end{array}$ & $\begin{array}{l}\text { Lithologic characteristics, } \\
\text { extent, shape, and thickness } \\
\text { of geologic units, } \\
\text { stratigraphic relations, } \\
\text { inferred ages of units, and } \\
\text { geologic history. }\end{array}$ & $\begin{array}{l}\text { Extent of units shown by } \\
\text { contact lines; altitudes shown } \\
\text { by contour lines; control } \\
\text { points shown by symbols; } \\
\text { includes glacial terrane maps, } \\
\text { stack-unit maps, and block } \\
\text { diagrams. }\end{array}$ & $\begin{array}{l}\text { Provides sound scientific } \\
\text { input for public policy } \\
\text { decisions regarding ground } \\
\text { water, facility siting and } \\
\text { planning, wetland and habitat } \\
\text { delineation, engineering and } \\
\text { geochemical considerations, } \\
\text { mineral resource exploration, } \\
\text { and economic assessments. }\end{array}$ \\
\hline
\end{tabular}


Table 3. Possible derivative maps and potential applications based on geologic mapping and related earth science data.

\begin{tabular}{ll}
\hline Ground-Water Considerations & \multicolumn{2}{l}{ Engineering Considerations and Hazard Assessment } \\
- Aquifer Delineation & $\bullet \quad$ Soil Amplification of Seismic Energy \\
- Aquifer Sensitivity/Vulnerability & $\bullet \quad$ Soil Period (Resonance) for Seismic Waves \\
- Depth to Top of Aquifer & $\bullet \quad$ Liquefaction Potential \\
- Depth to Top of the Water Table & $\bullet \quad$ Landslide Potential \\
- Hydraulic Properties & $\bullet \quad$ Subsidence Events and History \\
- Potentiometric Surfaces & $\bullet \quad$ Erosion History and Potential \\
- Potential Ground-Water Yield & $\bullet \quad$ Flooding Susceptibility \\
- Ground-Water Quality & $\bullet \quad$ Compressible Soils \\
- Recharge/Discharge & $\bullet \quad$ Poorly Drained Soils \\
- Ground-Water/Surface-Water Interactions & $\bullet \quad$ Load-Bearing Capacity \\
- Artesian Conditions & $\bullet \quad$ Flood Erosion and Sedimentation \\
- Sand Lenses and Fractures & $\bullet \quad$ Flood-Plain Risk Zones \\
& - Karst Features and Collapse Potential \\
\hline
\end{tabular}

\section{Facility Siting and Planning \\ - Waste-Disposal Planning \\ - Industrial, Commercial, Residential, and Infrastructure Siting/Planning}

Wetlands
- Wetland Delineation
- $\quad$ Hydric Soils
- Wetland History and Location
- Wetland Hydrogeology

Geochemical Considerations

- Radon Potential

- Baseline Ground-Water Geochemistry

- Baseline Geologic Material Geochemistry
Habitats

- Habitat Alterations

- Ecosystem Delineation, Reconstruction, and Maintenance

- Biodiversity Potential
Mineral Resources

- Sand and Gravel

- Shallow Bedrock

- Drift Gas

- Peat

- Overburden Thickness and Character
Both local (large scale, 1:24,000) and regional (small scale, such as 1:100,000) maps will be produced. In areas where maps are produced at both scales, there will be continual emphasis on the feedback of information between the detailed maps and regional maps. Regional maps-

- $\quad$ Provide a more robust depiction of the geology for subsequent 1:24,000-scale mapping in adjacent quadrangles within the region

- Help to explain the variation within geologic units, particularly aquifers

- Help to project newly recognized geologic features into adjacent areas and significantly improve the predictability of findings in smaller areas

- Provide county and State planners with a regional overview of geologic conditions that affect resource, hazard, and environmental issues

- $\quad$ Provide an immense overall educational value, showing large effects of continental glaciation and interglacial processes
Economic Assessments

- Property Values/Insurance Estimates

- Risk Assessments

- Benefit:Cost Studies

\section{DERIVATIVE MAPS}

Derivative maps provide information for custom applications and (1) are interpreted for resource development, hazard identification, and specific environmental protection, and (2) show single factors (such as hydraulic conductivity or grain size). Table 3 lists types of derivative maps and other information that can be derived from basic geologic maps. This list is not exhaustive nor will each study area provide all the listed derivative map products. Rather, production of derivative maps will be customer driven and based on specific needs (Kincare, 1989).

\section{ENABLING THE USER}

The ultimate challenges and value of this program are to create a new model for a dynamic and ongoing interface between earth scientists and users of scientific information. This interface will lead the five collaborating geological surveys into a new working relationship with their constituents. 
Earth scientists cannot work in isolation from the public, and cannot offer only highly technical, jargon-filled products that may not address the user's issues and needs. Under a new paradigm, geologic professionals will work in close partnership with local communities to recognize and define the issues. Together, they will apply geologic and other map information in an interactive, multidimensional information system that provides real-time support for decisions affecting resources, geologic hazards, and the environment.

This interface cannot be an after-the-fact addition to mapping projects. It will begin with the earliest stages of selecting the project area and defining the unique questions to be addressed in each area, and it will continue through to the application of the information to societal problems in the real world. To develop this interface, we propose a new position of an education/outreach $(\mathrm{E} / \mathrm{O})$ specialist in each survey. This specialist is a scientist, communicator, and educator, whose job will be to help close the communication gap between scientists and decisionmakers, helping each understand the needs and concerns of the other, developing a common vocabulary, and articulating common ground. The education/outreach coordinator's job is not to be the communicator, but rather to facilitate communication between scientists and decisionmakers, educators, and the general public.

\section{EDUCATION AND OUTREACH}

The education/outreach function (E/O) of the mapping program, led by the E/O specialists from each survey, is a significant tool for achieving positive outcomes through partnerships with information users. Creation of an effective decision-support system requires that we:

- Know what kinds of societal decisions can appropriately utilize surficial geologic information

- Understand what geologic information, and in what form, the makers of these particular decisions must have

- Know what kinds of ancillary information (demographic, economic, political, and so on) will be needed in combination with our surficial geologic information

- Understand economic and social issues to enable the surveys to provide innovative derivative products with strong user involvement

- Understand the decisionmaking process and how information can be used in it

- Demonstrate to decisionmakers the value in using our information

- Assure that the geologic information delivery system is conveniently available to, and supported for use by, decisionmakers and concerned citizens and that it successfully addresses significant issues in highly visible areas

The E/O staff is a critical segment of the program team, ensuring that project plans address the local concerns by developing effective channels of communication between project teams and all appropriate stakeholders. $\mathrm{E} / \mathrm{O}$ staff must have an understanding of and love for earth science, coupled with a well-honed ability to articulate science to nonscientists. They must join the mapping teams at the outset of the pilot phase and learn the basics of surficial geologic mapping, presentation of spatial data, and the resource, hazards, and environmental issues they pertain to. The E/O staff also must develop the ability to interact with local government, industry, and concerned citizen groups in decisionmaking. As leaders of the Liaison Committee, they will contact the community to develop relationships with decisionmakers and concerned citizen groups and will involve project scientists in the communication process. They also will work with survey economists to evaluate the social aspects of geologic-map use and will participate in tracking map usage by decisionmakers and other concerned citizens. This will require preparation of informational pamphlets and presentations.

It is essential that the E/O staff work with all project staff to plan the user interfaces and to prepare them for intense user interactions. The scientific staff must become involved with users to help them understand and use the information in making useful decisions for society. The scientist must be receptive to understanding the needs of the user community and the specific scientific conclusions that directly address the problems.

\section{CONTINUOUS REASSESSMENT OF MAPPING PRIORITIES}

The surficial geologic mapping program is designed to provide detailed information to study areas that presently are known to contain resources, hazards, or environmental challenges of significant societal relevance. As the program proceeds, new areas with similar or even higher needs for mapping may emerge. In such cases, resources for mapping these areas in cooperation with governmental or nongovernmental groups may be redirected by a Scientific Steering Committee of the Coalition or member surveys with input from the user community.

\section{RAPID RESPONSE TO DISASTER EVENTS}

Disaster events offer unique opportunities for applied research into causes, effects, and mitigation of recurring natural hazards. In addition, timely observations are invaluable to relief efforts. The surficial geologists in the mapping program are a significant pool of scientists who will respond to disastrous events, such as earthquakes, flash floods in small streams, large floods, landslides, or periods of rapid shoreline erosion along the Great Lakes. As a Rapid Response Team, these researchers will supply critical observations during and immediately following certain natural disasters. The program team also will make these findings 
rapidly available through a newly established geologic information delivery system and make the results available for later study.

\section{STRATEGY-DESIGN OF THE PROGRAM}

The Coalition surveys have demonstrated commitment to this program by allocating significant amounts of their limited resources in 1997-99 to ongoing and new surficial mapping activities that will provide background for the program. The Coalition's new mapping program consists of a pilot-study phase composed of a 3-year period of program development and mapping, followed by a 14 -year intensive mapping phase.

\section{PROGRAM COORDINATION}

A Scientific Steering Committee (Steering Committee), composed of experienced, senior surficial geologic mappers from each survey, Coalition State Geologists, and the Chief Scientist from the USGS Eastern Earth Surface Processes Team, will provide management oversight of the program (fig. 18). The Steering Committee will review program plans and set priorities for the pilot-study and intensive geologic mapping phases. The Steering Committee will ensure the following:

- Consistent production of high-quality map products in prioritized areas in a timely fashion

- Consistent compilation of geologic information on maps, map layers, and derivative map products and in digital data bases

- Commitment to providing scientific information that meets specific societal needs for sustainable development of ground-water and land resources, mitigation of hazards, and environmental protection

- Commitment to working with universities to train students in needed mapping and communication skills

- A high degree of cooperation among State surveys and the USGS

The five surveys will conduct collaborative field studies, drilling projects, and data analysis. Laboratory capabilities to investigate the physical, chemical, and geohydrologic characteristics of surficial deposits, exploratory drilling, geophysical surveys, and personnel all will be shared. These collaborative arrangements will optimize equipment capabilities and staff expertise and lessen duplication of services. Some laboratories will be upgraded to accommodate increases in numbers of analyses. All laboratories will develop protocols for sample collection and analysis in accordance with accepted standards.

The Steering Committee will designate a Project Coordination Team to help ensure collaboration among the surveys and timely delivery of map products. This team will consist of the geologists from each survey on the Steering Committee and other Coalition team members. This team, working with the Liaison Committees, will monitor the progress of the mapping projects in the four States and advise the Steering Committee to regenerate mapping deadlines and allocate resources to potentially challenging mapping areas or newly prioritized mapping areas. Each State survey will take the lead role in mapping and producing map products for its respective State. USGS staff will participate in some State mapping projects and will lead other mapping projects. The USGS and State geologists will communicate Coalition plans to the State geologic mapping advisory committees that prioritize STATEMAP projects. Coordination with local projects in STATEMAP and EDMAP programs (fig. 18) may lead to regional summary studies in some areas.

\section{PILOT-STUDY PHASE}

The purpose of the pilot-study phase is to begin geologic mapping in high-priority areas and to identify and train new personnel, develop field, analytical, and mapping protocols, expand laboratory capabilities, and develop information-delivery systems. Most importantly, the pilot phase will produce effective models of communication among geological survey teams, decisionmakers, and the public. Four high-priority map areas will be selected for the pilot-study projects.

\section{PROJECT PLANNING, PROTOCOLS, TRAINING, AND PREPARATION: YEAR 1}

A program of this scope requires significant preparation, planning, and commitment from the USGS and State surveys. For a successful effort, all five surveys must place a high priority on obtaining the required additional resources prior to the start of the actual mapping. Table 4 shows the present in-house capabilities of each survey to conduct field sampling and description of geologic materials, perform laboratory analyses, and maintain a high level of mapping support. The table also shows future needs for enhancing those capabilities to meet the increased demands of the program. Some of the capabilities listed in table 4 are discussed below along with some training needs that are not in table 4 .

Surficial geology field sampling and description.Stratigraphic drilling and expanded logging and sampling operations are primary requirements for success of this program because of the need to depict the thickness and extent of subsurface geologic materials. Drill-rig start-up, maintenance, and refurbishing costs and some new drilling capabilities will be needed. In addition, the USGS drilling rig and crew time must be firmly scheduled in the short term.

Surficial geology laboratory analysis.-Current laboratory capabilities at the five surveys are inadequate to process all of the analyses required for this comprehensive mapping program. For example, all five surveys will require additional funds to conduct routine particle-size determinations, to study mineralogy and geochemistry, and to evaluate engineering properties of geologic materials. 
The surveys need the ability to produce these fundamental data, and laboratories must be set up and running before the mapping activities begin. Support for USGS geochemistry contracts and some State geochemistry and mineralogy laboratories also will be required. In addition, resources will be allocated for contracting with laboratories outside the Coalition and possibly outside the United States to take advantage of cutting-edge technology. Staffing of the laboratories will require five additional people.

Surficial geology mapping support.-Presently, there are fewer than 20 geologists with glacial-surficial mapping expertise in the geologic mapping programs of the five surveys. Some of these already are committed to existing programs. The pilot-study phase will require 10 additional surficial geologists and logistical support (such as field vehicles and geophysical services) in order to proceed at the planned pace. In addition, all surficial geologists must be properly trained and familiar with the geology of the region.

Remote sensing of the subsurface using various geophysical techniques (such as seismic reflection and groundpenetrating radar) is required to depict the stratigraphic relationships of subsurface units. In addition, funds are required for training within the five surveys, equipment purchase and lease, and computer analysis of data.
The ability to deliver the information developed by this project is currently minimal. Expertise is required in database design and management of GIS systems, graphic presentation of three-dimensional data, quality control (three people per organization), and digital illustration, layout, and prepress work (seven individuals for all surveys). Table 4 shows that hardware and software must be purchased by the five surveys to efficiently store, retrieve, and analyze data. The design and development of the basic data-management system must be completed in time to accept data generated during year 2 of the pilot program. Fortunately, existing data-management systems in the four States and the USGS are starting points.

Staff for education and outreach endeavors (one individual for each survey) will be identified and trained. Contacts with the information-user community will be initiated. Preliminary information describing the program goals and products will be prepared and distributed.

\section{PILOT-STUDY PHASE MAPPING PROJECTS: YEAR 2, YEAR 3}

The purpose of years 2 and 3 is to begin mapping of highpriority areas. Most importantly, however, the five surveys will be developing mapping protocols, establishing good working relationships with the user community, and deciding

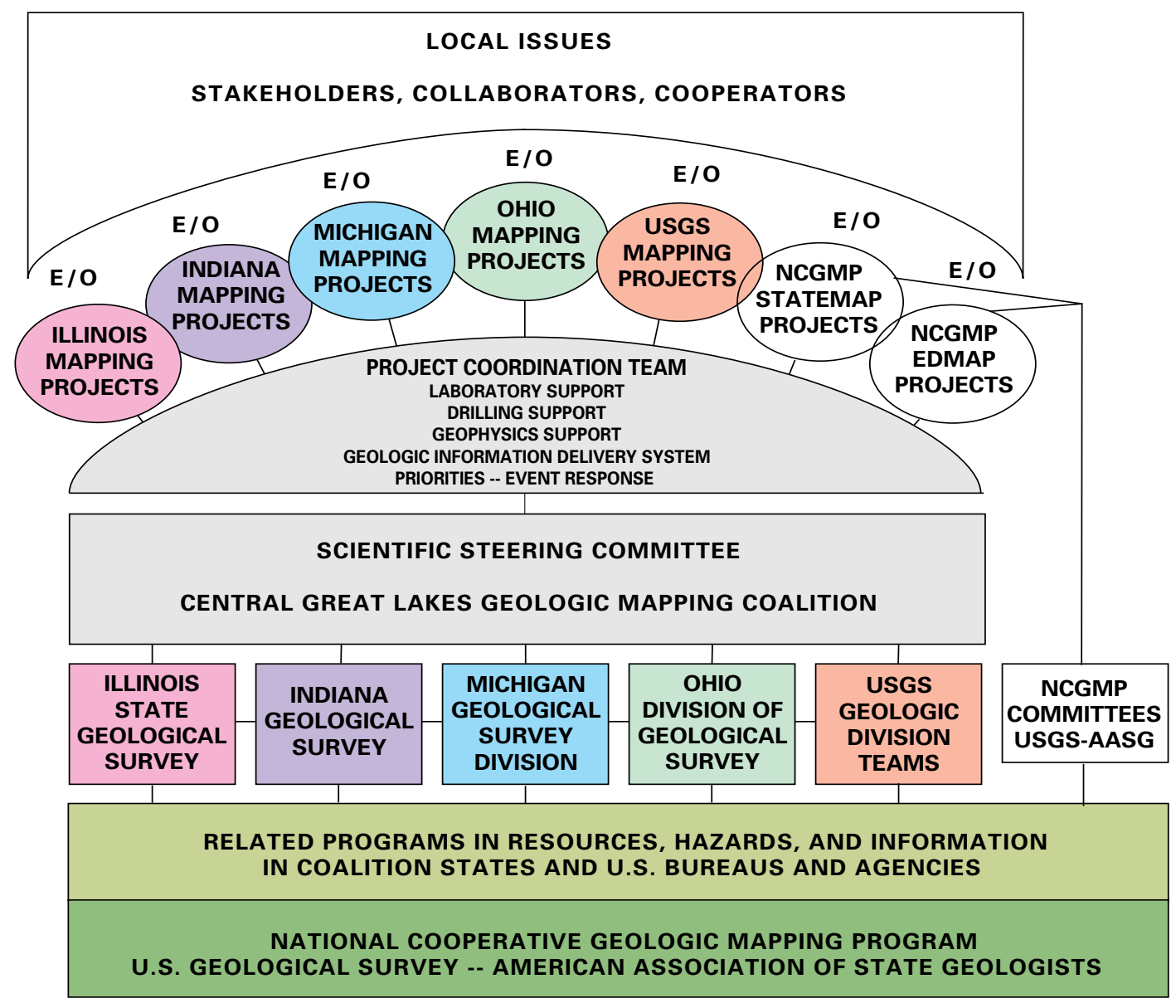

Figure 18. Program organization and coordination. E/O, education and outreach. 
on the most efficient ways to work together in sharing equipment, laboratories, and personnel, while minimizing costs.

\section{SELECTION OF PILOT AREAS}

Prioritization of new geologic mapping is based on known societal needs and present knowledge of the thickness and complexity of the surficial deposits in the region (figs. 5, 7). The program will begin with the selection of four pilotstudy areas (table 5, fig. 19). The pilot studies are intended as smaller versions of the 14-year intensive geologic mapping phase. They are necessary to implement program methods, test the concepts, technology, and organization of the total program, and begin the collection of new scientific data.
Selection of pilot-study areas will be made by the Steering Committee in consultation with the user community from a list of 11 potential areas (table 5). Stakeholders will be asked to participate in the pilot-study program over its entire duration. Criteria for pilot-study areas include the following:

- Economic or environmental concerns of compelling interest to local stakeholders

- Thick and complex geology that offers challenging tests of the new technologies planned for the program in a variety of settings (such as urban, suburban, rural, coastal)

- $\quad$ Significant opportunities to explore the utility of multilayer derivative maps that combine surficial geologic information with data derived from other sources

Table 4. In-house capabilities and needs for field sampling and description, laboratory analysis, and mapping support.

[Survey abbreviations: USGS, U.S. Geological Survey; IGS, Indiana Geological Survey; ISGS, Illinois State Geological Survey; OGS, Ohio Division of Geological Survey; MGS, Michigan Geological Survey Division. The last column shows the estimated cost of new capabilities needed by all five surveys in thousands of dollars. Blank spaces indicate capabilities that are not needed presently by survey(s)]

\begin{tabular}{|c|c|c|c|c|c|c|c|}
\hline \multirow{2}{*}{ Method/procedure } & \multirow{2}{*}{ Type } & \multicolumn{5}{|c|}{ In-house capabilities/needs* } & \multirow[b]{2}{*}{$\$$} \\
\hline & & USGS & IGS & ISGS & OGS & MGS & \\
\hline \multicolumn{8}{|c|}{ Surficial geology field sampling and description } \\
\hline Sediment coring to $1500 \mathrm{ft}$ depth & Sampling & $\mathrm{Y}$ & Y20 & Y20 & Y20 & & 60 \\
\hline Rotary cuttings to $1000 \mathrm{ft}$ depth & Sampling & $\mathrm{Y}$ & Y20 & Y20 & Y20 & Y20 & 80 \\
\hline $\begin{array}{l}\text { Solid stem auger to } 125 \mathrm{ft} \text { depth } \\
\text { Hollow stem auger }\end{array}$ & Sampling & Y40 & Y & & & & 40 \\
\hline Split spoon, shelby tube, $75-150 \mathrm{ft}$ & Sampling & Y5 & Y5 & Y5 & $\mathrm{Y}$ & & 15 \\
\hline Continuous sampler, 75-180 ft & Sampling & Y5 & & Y5 & Y5 & Y5 & 20 \\
\hline \multicolumn{8}{|l|}{ Probing } \\
\hline Geoprobe, PowerProbe $80 \mathrm{ft}$ & Sampling & $\mathrm{Y}$ & & $\mathrm{Y}$ & & & \\
\hline Giddings $45 \mathrm{ft}$ & Sampling & 20 & & Y10 & & & 30 \\
\hline Hoverprobe & Sampling & $\mathrm{Y}$ & & & & & \\
\hline Vibracore & Sampling & & & & $\mathrm{Y}$ & & \\
\hline Penetrometer & Description & $\mathrm{Y}$ & & $\mathrm{Y}$ & & $\mathrm{Y}$ & \\
\hline \multicolumn{7}{|l|}{ Downhole Logging } & \\
\hline P-wave velocity & Logging & $\mathrm{Y}$ & & $\mathrm{Y}$ & & & \\
\hline Resistivity & Logging & $\mathrm{Y}$ & & $\mathrm{Y}$ & & & \\
\hline Gamma & Logging & $\mathrm{Y}$ & Y40 & $\mathrm{Y}$ & 40 & $\mathrm{Y}$ & 80 \\
\hline Neutron & Logging & $\mathrm{Y}$ & & $\mathrm{Y}$ & & $\mathrm{Y}$ & \\
\hline Caliper & Logging & $\mathrm{Y}$ & & $\mathrm{Y}$ & & & \\
\hline Vane shear & Logging & $\mathrm{Y}$ & & $\mathrm{Y}$ & & & \\
\hline Acoustic televiewer & Logging & $\mathrm{Y}$ & $\mathrm{Y}$ & $\mathrm{Y}$ & & & \\
\hline Magnetic susceptibility & Logging & $\mathrm{Y}$ & $\mathrm{Y}$ & $\mathrm{Y}$ & & & \\
\hline Spectral gamma & Logging & $\mathrm{Y}$ & & & & & \\
\hline $\begin{array}{l}\text { Core splitting and sensitive subsampling } \\
\text { (bulk density, moisture content }\end{array}$ & Description & $\mathrm{Y}$ & $\mathrm{Y}$ & $\mathrm{Y}$ & $\mathrm{Y}$ & $\mathrm{Y}$ & \\
\hline Photography & Description & $\mathrm{Y}$ & $\mathrm{Y}$ & $\mathrm{Y}$ & $\mathrm{Y}$ & $\mathrm{Y}$ & \\
\hline \multicolumn{8}{|l|}{$\begin{array}{l}\text { Visual descriptions (Munsell color, lithology, } \\
\text { bedding, texture, fractures, contacts, horizon, } \\
\text { structure, cutans/silans, reaction, depth, } \\
\text { thickness, \%recovery...) }\end{array}$} \\
\hline \multicolumn{8}{|c|}{ Surficial geology laboratory analysis } \\
\hline General sample preparation capability & $\begin{array}{l}\text { Description } \\
\text { and analysis }\end{array}$ & $10+5$ & 5 & 5 & $10+5$ & 5 & 45 \\
\hline $\begin{array}{l}\text { Bulk sampling, sample splitting, mechanical } \\
\text { size separation }\end{array}$ & Description & $Y$ & $Y$ & $Y$ & $Y$ & $Y$ & 0 \\
\hline $\begin{array}{l}\text { Particle size (Sedigraph, pipette, hydrometer, } \\
\text { sieve, ...) }\end{array}$ & Analysis & 40 & 40 & 40 & 40 & 40 & 200 \\
\hline Carbonate content (Chittick, Leco) & Analysis & 2 & 2 & 2 & 2 & 2 & 10 \\
\hline X-ray diffraction & Analysis & Y15 & & Y15 & & & 30 \\
\hline Bulk density, water content, void ratio & Analysis & 5 & 2 & Y & 5 & 5 & 17 \\
\hline Atterburg limits (LL, PL) & Analysis & 2 & 2 & 2 & 2 & 2 & 10 \\
\hline
\end{tabular}


Table 4. In-house capabilities and needs for field sampling and description, laboratory analysis, and mapping support—Continued.

\begin{tabular}{|c|c|c|c|c|c|c|c|}
\hline \multirow{2}{*}{ Method/procedure } & \multirow{2}{*}{ Type } & \multicolumn{5}{|c|}{ In-house capabilities/needs* } & \multirow[b]{2}{*}{$\$$} \\
\hline & & USGS & IGS & ISGS & OGS & MGS & \\
\hline \multicolumn{8}{|c|}{ Surficial geology laboratory analysis-Continued } \\
\hline Permeameter & Analysis & 2 & $\mathrm{Y}$ & $\mathrm{Y}$ & 2 & 2 & 6 \\
\hline $\begin{array}{l}\text { Other physical properties (Qu, direct shear, } \\
\text { triaxial compression, compaction, slake } \\
\text { durability, ...) }\end{array}$ & Analysis & 10 & 5 & 10 & 10 & 10 & 45 \\
\hline $\begin{array}{l}\text { Bulk magnetic susceptibility } \\
{ }^{14} \mathrm{C}\end{array}$ & $\begin{array}{l}\text { Analysis } \\
\text { Dating }\end{array}$ & $\begin{array}{c}2 \\
Y 20\end{array}$ & $\mathrm{Y}$ & $\begin{array}{c}Y \\
Y 20\end{array}$ & $\mathrm{Y}$ & 2 & $\begin{array}{r}4 \\
40\end{array}$ \\
\hline $\begin{array}{l}\text { Magnetic remanence (paleomagnetic } \\
\text { measurements) }\end{array}$ & Dating & Y5 & & & & & 5 \\
\hline Varve counting & Dating & $\mathrm{Y}$ & & & & & \\
\hline $\begin{array}{l}\text { Other dating methods (U series, TL, OSL, } \\
\text { ESR, }{ }^{10} \mathrm{Be},{ }^{3} \mathrm{H}^{210}{ }^{210} \mathrm{~Pb},{ }^{17} \mathrm{Cs} \ldots \text {...) }\end{array}$ & Dating & Y5 & & Y10 & & & 15 \\
\hline Sensitive geochemistry (pore water Eh-pH, & Analysis & $\mathrm{Y}$ & & Y & & & \\
\hline Organic geochemistry of sediments & Analysis & $\mathrm{Y}$ & & $\mathrm{Y}$ & & & \\
\hline Organic carbon and nitrogen (LOI) & Analysis & $\mathrm{Y}$ & & $\mathrm{Y}$ & & & \\
\hline Geochemistry - metals & Analysis & Y10 & & $\mathrm{Y}$ & & & 10 \\
\hline Oxides & Analysis & Y5 & & $\mathrm{Y}$ & & & 5 \\
\hline Selective leach & Analysis & Y5 & & & & & 5 \\
\hline Stable isotopes $(\mathrm{C}, \mathrm{H}, \mathrm{N}, \mathrm{O}, \mathrm{S})$ & Analysis & Y15 & & Y15 & & & 30 \\
\hline X-ray imaging & Description & Y5 & & & & & 5 \\
\hline Spectral/gray-scale scan & Description & & & Y2 & & & 2 \\
\hline Thin sections & Description & Y2 & Y2 & Y2 & & & 6 \\
\hline Smear slides & Description & $\mathrm{Y}$ & & $\mathrm{Y}$ & & & \\
\hline Oriented aggregate slides & Description & $\mathrm{Y}$ & & $\mathrm{Y}$ & & & \\
\hline \multicolumn{8}{|l|}{ Mineral separations (magnetic, heavy, } \\
\hline light, ...) & Analysis & $\mathrm{Y}$ & $\mathrm{Y}$ & $\mathrm{Y}$ & & & \\
\hline Sand/silt mineralogy & Analysis & $\mathrm{Y}$ & & $\mathrm{Y}$ & & & \\
\hline SEM (scanning electron microscope) & Analysis & $\mathrm{Y}$ & & $\mathrm{Y}$ & & & \\
\hline Microprobe & Analysis & $\mathrm{Y}$ & & & & & \\
\hline Pollen and spores & Analysis & $\mathrm{Y}$ & & $\mathrm{Y}$ & & & \\
\hline Diatoms & Analysis & $\mathrm{Y}$ & & & & & \\
\hline Macrofossils (plant and animal) & Analysis & $\mathrm{Y}$ & & $\mathrm{Y}$ & & & \\
\hline $\begin{array}{l}\text { Microfossils (ostracodes, including } \\
\text { geochemistry and isotopes) }\end{array}$ & Analysis & $\mathrm{Y}$ & & $\mathrm{Y}$ & & & \\
\hline \multicolumn{8}{|c|}{ Surficial geology mapping support } \\
\hline Field vehicles & Logistical support & 60 & 60 & 60 & 60 & 60 & 300 \\
\hline Boat & Logistical support & $\mathrm{Y}$ & $\mathrm{Y}$ & $\mathrm{Y}$ & $\mathrm{Y}$ & & \\
\hline GPS (global positioning system) & Field data collection & $\mathrm{Y}$ & 15 & $\mathrm{Y}$ & 15 & $\mathrm{Y}$ & 30 \\
\hline Seismic refraction & Field data collection & $\mathrm{Y}$ & & $\mathrm{Y}$ & & & \\
\hline Seismic reflection (land) & Field data collection & Y20 & & Y10 & & & 30 \\
\hline Electrical Earth resistivity & Field data collection & $\mathrm{Y}$ & $\mathrm{Y}$ & $\mathrm{Y}$ & & $\mathrm{Y}$ & \\
\hline EM (electro-magnetism) & Field data collection & Y & $\mathrm{Y}$ & $\mathrm{Y}$ & & $\mathrm{Y}$ & \\
\hline Ground penetrating radar & Field data collection & Y100 & & & & $\mathrm{Y}$ & 100 \\
\hline Marine geophysics & Field data collection & $\mathrm{Y}$ & & $\mathrm{Y}$ & $\mathrm{Y}$ & & \\
\hline Digitizer & Data capture & $\mathrm{Y}$ & $\mathrm{Y}$ & $\mathrm{Y}$ & 10 & $\mathrm{Y}$ & 10 \\
\hline Photogrammetry & Data capture/analysis & $\mathrm{Y}$ & & $\mathrm{Y}$ & & & \\
\hline Computer hardware & Data capture/analysis & 30 & 30 & 30 & 30 & 30 & 150 \\
\hline \multicolumn{8}{|l|}{ GIS: } \\
\hline Arcview & Data capture/analysis & 2 & $\mathrm{Y}$ & $\mathrm{Y}$ & 2 & 2 & 6 \\
\hline Arc/Info & Data capture/analysis & $\mathrm{Y}$ & $\mathrm{Y}$ & $\mathrm{Y}$ & 6 & & 6 \\
\hline Intergraph & Data capture/analysis & & & & & 6 & 6 \\
\hline \multicolumn{8}{|l|}{ 3-D analysis: } \\
\hline EarthVision (with operator) & Data capture/analysis & 120 & & Y30 & & & 150 \\
\hline "Low-end" & Data capture/analysis & 10 & 10 & 10 & 10 & 10 & 50 \\
\hline \multicolumn{8}{|l|}{ Relational data base: } \\
\hline Oracle & Data capture/analysis & $\mathrm{Y}$ & & $\mathrm{Y}$ & $\mathrm{Y}$ & $\mathrm{Y}$ & \\
\hline Access & Data capture/analysis & & $\mathrm{Y}$ & & $\mathrm{Y}$ & $\mathrm{Y}$ & \\
\hline Desktop publishing & Publication & $\mathrm{Y}$ & $\mathrm{Y}$ & $\mathrm{Y}$ & $\mathrm{Y}$ & $\mathrm{Y}$ & \\
\hline Large plotter & Publication & $\mathrm{Y}$ & 10 & $\mathrm{Y}$ & 10 & $\mathrm{Y}$ & \\
\hline
\end{tabular}

* Capabilities and needs are indicated as follows:

$\mathrm{Y}=$ Yes, capability exists

Y10 = Some capability exists, additional needs in thousands of dollars

$10=$ New capability needed in thousands of dollars 
Table 5. Proposed mapping areas of the pilot-study phase.

\begin{tabular}{|c|c|c|c|}
\hline $\begin{array}{l}\text { Area } \\
\text { (fig. 19) }\end{array}$ & $\begin{array}{l}\text { Resource, hazards, and } \\
\text { environmental issues }\end{array}$ & $\begin{array}{l}\text { Thickness } \\
\text { of deposits }\end{array}$ & Glacial terrane and characteristic deposits \\
\hline $\begin{array}{l}\text { (A) Akron- } \\
\text { Canton, } \\
\text { Ohio }\end{array}$ & $\begin{array}{l}\text { Considerable urban and suburban } \\
\text { growth pressures land and ground- } \\
\text { water resources; numerous contam- } \\
\text { ination problems exist; brownfields } \\
\text { need cleanup. }\end{array}$ & $<50-200 \mathrm{ft}$ & $\begin{array}{l}\text { Moraine belt; complex interlobate till-cored and } \\
\text { stratified moraines that cover the buried-valley } \\
\text { aquifers; headwaters of the Cuyahoga River. }\end{array}$ \\
\hline $\begin{array}{l}\text { (B) Berrien } \\
\text { County, } \\
\text { Michigan, } \\
\text { and South } \\
\text { Bend } \\
\text { Valley, } \\
\text { Indiana }\end{array}$ & $\begin{array}{l}\text { Outwash in the South Bend area } \\
\text { forms a vulnerable aquifer used by } \\
\text { the city; over } 40 \text { miles of Lake Michigan } \\
\text { shoreline are subject to erosion; large } \\
\text { areas of abandoned industrial sites in } \\
\text { South Bend and Benton Harbor need } \\
\text { cleanup. }\end{array}$ & $<100-300 \mathrm{ft}$ & $\begin{array}{l}\text { Moraine belt; dominantly massive fan-head-cored } \\
\text { moraine and exposed fan. Three Michigan Lobe } \\
\text { moraine units cross the region as well as outwash } \\
\text { from each moraine; coastal erosion due to Holocene } \\
\text { lake-level changes; Saginaw Lobe sediments at } \\
\text { the eastern edge of the area. }\end{array}$ \\
\hline $\begin{array}{l}\text { (C) Lake } \\
\text { County, } \\
\text { Illinois }\end{array}$ & $\begin{array}{l}\text { Because of rapid urban development, } \\
\text { the county has requested aid to charac- } \\
\text { terize its ground-water resources. Plan- } \\
\text { ning officials are concerned about the } \\
\text { interaction of new land and water uses } \\
\text { with wetlands and agriculture and } \\
\text { shoreline tracts. }\end{array}$ & $100-300 \mathrm{ft}$ & $\begin{array}{l}\text { Moraine belt and till plain deposits of Wisconsin } \\
\text { Episode glaciation overlie those of Illinois Episode } \\
\text { and possibly older glaciations; the western part of } \\
\text { the county contains ice-stagnation deposits. The } \\
\text { eastern part contains a beach ridge and dune } \\
\text { complex along Lake Michigan. }\end{array}$ \\
\hline $\begin{array}{l}\text { (D) Illinois } \\
\text { River } \\
\text { Valley, } \\
\text { Illinois }\end{array}$ & $\begin{array}{l}\text { Contamination problems in Peoria } \\
\text { require definition of aquifers and } \\
\text { their protecting fine-grained units; } \\
\text { nitrates and pesticides have been } \\
\text { detected in shallow wells in a large } \\
\text { irrigated agricultural area. }\end{array}$ & $25-200 \mathrm{ft}$ & $\begin{array}{l}\text { Till plain, river valley outwash, and dune sheets; } \\
\text { complex stratigraphy of multiple glacial sequences } \\
\text { and loess; unique ground-water/surface-water } \\
\text { interconnection. }\end{array}$ \\
\hline $\begin{array}{l}\text { (E) } \\
\text { Bloomington } \\
\text {-Normal, } \\
\text { Illinois }\end{array}$ & $\begin{array}{l}\text { The community relies on the Mahomet } \\
\text { aquifer and is searching for more water } \\
\text { due to an increase in demand; soil } \\
\text { contamination indicates a need to } \\
\text { document the surface- to ground-water } \\
\text { connection. }\end{array}$ & $200-400 \mathrm{ft}$ & $\begin{array}{l}\text { Moraine belt/till plain/buried valley; } \\
\text { thick sequence of Wisconsin Episode } \\
\text { (and older) glacial sediments; } \\
\text { the Mahomet aquifer extends into this area. }\end{array}$ \\
\hline $\begin{array}{l}\text { (F) Mahomet } \\
\text { Valley, east- } \\
\text { central } \\
\text { Illinois }\end{array}$ & $\begin{array}{l}\text { The Mahomet aquifer receives water } \\
\text { from both the glacial deposits and } \\
\text { bedrock; upper aquifers are contaminated } \\
\text { from agricultural applications; } \\
\text { water usage is also an issue. }\end{array}$ & $200-350 \mathrm{ft}$ & $\begin{array}{l}\text { Buried valley/moraine belt; regional } \\
\text { pre-Illinois Episode glaciation aquifer is } \\
\text { hidden beneath thick deposits of multiple } \\
\text { glaciations; shallow and restricted Illinois } \\
\text { Episode aquifers overlie the Mahomet aquifer. }\end{array}$ \\
\hline $\begin{array}{l}\text { (G) Marion, } \\
\text { Indiana }\end{array}$ & $\begin{array}{l}\text { Problems include the origin of the } \\
\text { water-bearing unit and the ability } \\
\text { of clay till to protect underlying } \\
\text { water supplies. }\end{array}$ & $100-200 \mathrm{ft}$ & $\begin{array}{l}\text { Till plain/buried valley terrane; } \\
\text { Indiana's central plain where it merges with } \\
\text { moraines of the Erie Lobe; clay till overlies the } \\
\text { city's well field. }\end{array}$ \\
\hline $\begin{array}{l}\text { (H) Central } \\
\text { till plain, } \\
\text { Indiana }\end{array}$ & $\begin{array}{l}\text { Agricultural chemicals contaminate } \\
\text { the upper aquifer, and the connection } \\
\text { to the deeper buried valley is poorly } \\
\text { understood. }\end{array}$ & $100-200 \mathrm{ft}$ & $\begin{array}{l}\text { Till plain and broad buried valley terrane; flat } \\
\text { ground-moraine topography hides the buried } \\
\text { Anderson Valley, which is poorly explored, } \\
\text { contains a complex glacial/lacustrine sequence, } \\
\text { and is an important source of ground water. }\end{array}$ \\
\hline
\end{tabular}


Table 5. Proposed mapping areas of the pilot-study phase-Continued.

\begin{tabular}{|c|c|c|c|}
\hline $\begin{array}{l}\text { Area } \\
\text { (fig. 19) }\end{array}$ & $\begin{array}{l}\text { Resource, hazards, and } \\
\text { environmental issues }\end{array}$ & $\begin{array}{l}\text { Thickness } \\
\text { of deposits }\end{array}$ & Glacial terrane and characteristic deposits \\
\hline $\begin{array}{l}\text { (I) Tri-State } \\
\text { area, } \\
\text { Indiana, } \\
\text { Michigan, } \\
\text { and Ohio }\end{array}$ & $\begin{array}{l}\text { In this important agricultural } \\
\text { production zone, agricultural } \\
\text { chemicals may contaminate the } \\
\text { upper aquifer; significant trans- } \\
\text { portation corridors cross the area. }\end{array}$ & $200-400 \mathrm{ft}$ & $\begin{array}{l}\text { Thick interlobate moraines that formed } \\
\text { between Erie and Saginaw Lobes; terrane is } \\
\text { difficult to map due to interbedded } \\
\text { stratigraphic units and total thickness. }\end{array}$ \\
\hline $\begin{array}{l}\text { (J) Allen } \\
\text { County, } \\
\text { Indiana }\end{array}$ & $\begin{array}{l}\text { Ground water is the principal } \\
\text { source of water for over half } \\
\text { of the county residents; suburban } \\
\text { encroachment on limestone quarries } \\
\text { has led to zoning problems. }\end{array}$ & $30-300 \mathrm{ft}$ & $\begin{array}{l}\text { Vast lake plain with meltwater drainage ways; } \\
\text { several moraines; three known late Wisconsin } \\
\text { Episode glacial sequences. }\end{array}$ \\
\hline $\begin{array}{l}\text { (K) Southern } \\
\text { Lake Erie, } \\
\text { Ohio }\end{array}$ & $\begin{array}{l}\text { Issues include rapid coastal } \\
\text { development, nonpoint-source } \\
\text { contamination, and sediment loading } \\
\text { problems, ground-water/surface-water } \\
\text { interactions, and location of aggregate } \\
\text { resources; characterization of wetlands, } \\
\text { loss of fish habitats, and introduction of } \\
\text { exotic species are also problems. }\end{array}$ & $<50-200 \mathrm{ft}$ & $\begin{array}{l}\text { Beach/dune/lacustrine suite; broad buried } \\
\text { valley terrane; complex till plain and bedrock } \\
\text { knob terrane. }\end{array}$ \\
\hline
\end{tabular}

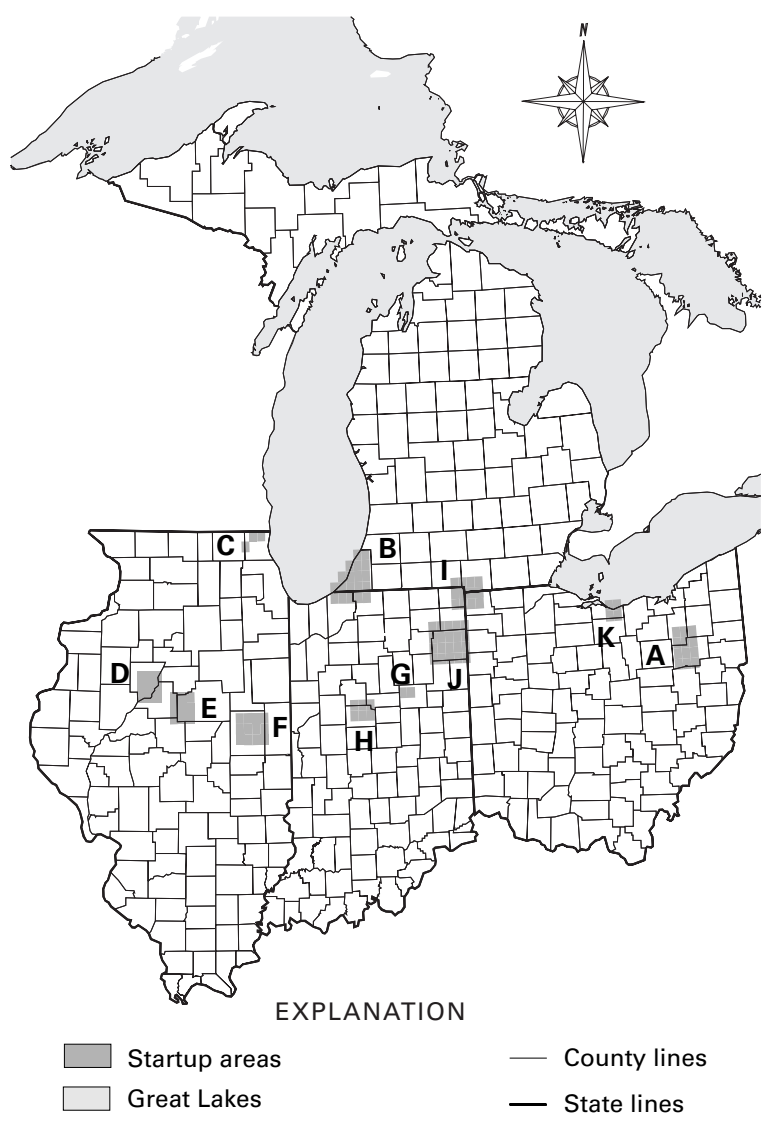

Figure 19. Proposed mapping areas of the pilot-study phase of the Central Great Lakes Geologic Mapping Program.
Figure 19 shows the distribution of the 11 proposed pilot-study areas in the region. Pilot-study projects will require different methods and intensity of study in the varying glacial terranes.

\section{DEVELOPMENT OF SYSTEMATIC STUDY APPROACH}

The pilot studies will activate the extensive organizational infrastructure needed for the larger program. Firstyear activities in each project area begin with obtaining additional stakeholder input to identify local issues, collecting and evaluating existing geologic information, and focusing ongoing logging and sampling operations (fig. 20). This information will be assembled into a data base and combined with data collected during the project. On the basis of this background information and preliminary field investigations, a detailed project design will be developed.

The second year consists of intensive field work, data analysis, and production of preliminary basic map products. Because training, procedure development, and learning to collaborate are major outcomes of the pilot phase, scientists from all surveys will take part in each pilot study. Therefore, the time frames and developmental costs for the pilot studies greatly will exceed the production costs for a comparable map area in the intensive phase of the program.

The second year also includes completion of strategically located core holes and geophysically logged wells and test holes. Locations will be chosen on the basis of available water-well data, existing logged and sampled wells, and 


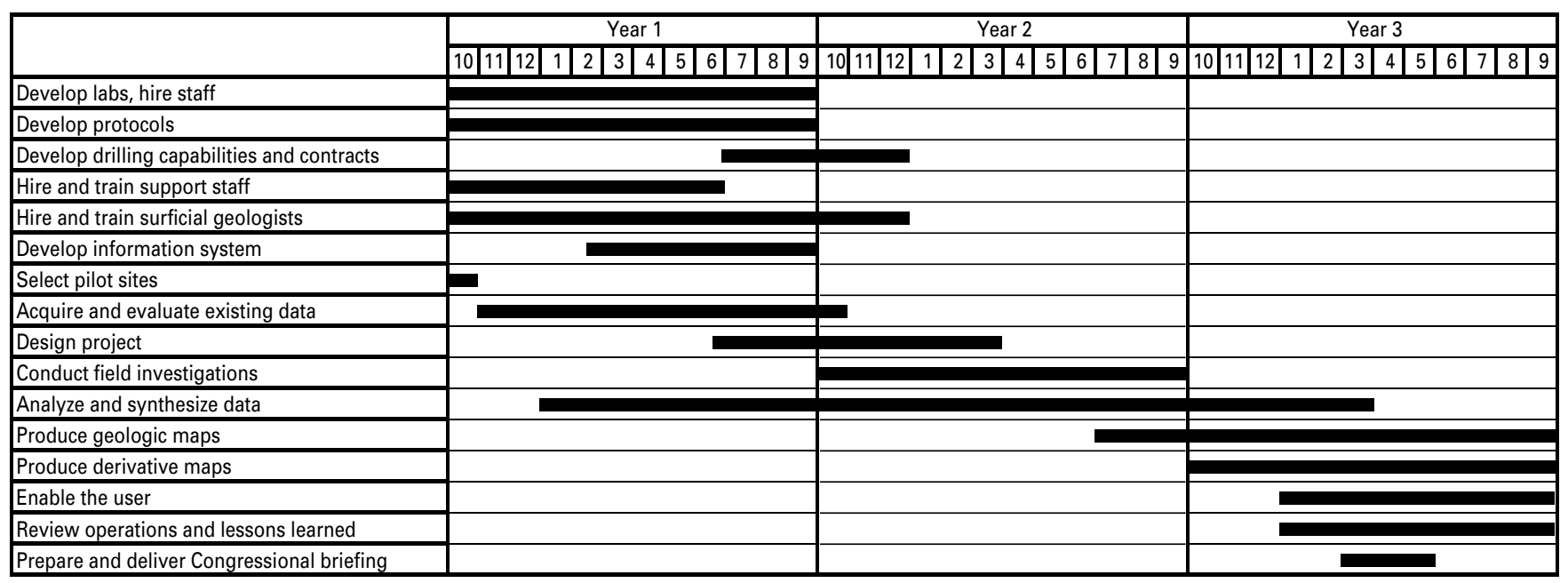

Figure 20. Time line for pilot-study mapping project. Fiscal years run from October through September; the months are shown under each year (10-12, 1-9).

engineering and oil and gas data in areas of thick and thin cover. The third pilot year concentrates on the conversion of information into a geologic information delivery system.

A challenge of the pilot phase will be learning to work in cooperation with local government officials, representatives of private industry, and public interest groups to apply the information we produce to real-world issues of concern to various stakeholders. A new type of scientist-interpreter will be required to lead this outreach activity, and new skills will be required of the program scientists. At the end of the pilot phase, a major operational review by the five surveys and the user community will assess the lessons learned.

\section{INTENSIVE GEOLOGIC MAPPING PHASE: YEAR 4 THROUGH YEAR 17}

\section{PRIORITIZATION OF MAPPING}

The 14-year intensive surficial geologic mapping phase will focus detailed 1:24,000-scale mapping in the highest priority areas of the four States (fig. 21, table 6). These areas were determined to be of highest priority for mapping by the State Geological Surveys in consultation with user groups. These include urban-suburban areas, areas of high recreational use, areas with point-source and non-point-source environmental problems, transportation corridors, or areas with known hazards. Mapping at a detailed scale will help develop the regional geologic framework and stratigraphy and will serve as anchors for regional coverage. The basic geologic framework also will serve as the base for development of numerous derivative maps addressing environmental and resource issues particular to the region.

\section{GENERAL APPROACH AND PROJECT SCHEDULE}

The procedure for completing a map in the intensive mapping phase is similar to that for mapping in the pilot phase (fig. 20), except that the anticipated time for completing a mapping cycle is shortened to 1.5 years (fig. 22). Project outreach and geologic information delivery protocols established in the pilot phase will be implemented and modified to fit local needs.

Figure 22 shows the sequence of activities within a 1.5year map cycle to map one quadrangle by a full-time surficial geologist supported by appropriate field, laboratory, information, and outreach specialists. Figure 23 shows the 14-year, full-implementation schedule for completion of geologic mapping in the four States. In each 1.5-year mapping cycle, about 12 maps, each equivalent in area to about one $7.5^{\prime}$ quadrangle (about 56 square miles), will be completed in each State. In each State, mapping typically could be conducted by eight State and two USGS geologists. The first 6 months of each cycle overlap with the activities of the last 6 months of the preceding cycle. The middle part of each cycle is concentrated field work. Including overlap times, three cycles of mapping are completed every 3.5 years. The intensive-phase schedule extends from year 4 to year 17 and includes 12 cycles of mapping, resulting in over 8,000 square miles being completed in the highest priority areas of each State.

\section{REGIONAL MAPS AND ANALYSIS: YEAR 4 THROUGH YEAR 17}

Synthesis of the detailed maps is planned to begin during the second cycle in year 5, whereby 1:24,000-scale geologic information and derivative data are compiled onto 
1:100,000-scale base maps or county maps. Regional-scale three-dimensional geologic maps will be produced during the 14-year intensive mapping phase to provide (1) data in large areas where data are sparse and where detailed mapping will not be focused and (2) a framework for possible synthesis of the detailed mapping projects.

\section{BEYOND YEAR 17}

At the end of the 14-year intensive surficial geologic mapping phase, more than 32,000 square miles in 17 highpriority areas will have been mapped. The knowledge gained will expedite mapping in new high-priority areas. Furthermore, a trained staff, new mapping techniques, and use of a fully functioning geologic information delivery system will speed the production of new maps. Following completion of the program, the State Geological Surveys will continue to update and make the geologic information delivery system available for decision support within the States. This will include addition of new data from geologic, construction, engineering, and environmental studies, as well as periodic revision of geologic interpretations. The geologic information delivery system will make it practical for the surveys to maintain a growing surficial geology data base, permit regular updating of surficial geology maps, and assist in the production of smaller scale regional maps, all of which will promote continuance of geologic mapping programs.

The State Geological Surveys also will assume primary responsibilities for future completion of mapping in areas designated as high priority, which should be directed toward rural issues as well as higher visibility urban issues. This future phase will continue to rely heavily on resources developed and nourished through partnerships among State government, local government, and industry. The USGS will continue to coordinate regional syntheses, products, and digital data bases that support the National Cooperative Geologic Map data base.

\section{PROGRAM BUDGETS}

The annual total costs of the fully implemented pilotstudy phase and the intensive mapping phase are projected to be about $\$ 6.7$ million and $\$ 11.9$ million, respectively. Annual support from existing programs of the five surveys will range up to about \$1 million and \$2 million for the pilot and intensive mapping phases, respectively. Costs of new equipment and personnel, field studies, and publications are spread over the 17-year program.

The budget for the first year of the pilot-study phase includes major expenditures for equipment to support laboratory and mapping activities and funds for geophysical and geochemical surveys. The budget for the second year supports field work, drilling and geophysical activities, laboratory operations, development of a geologic information delivery system, and full staffing of the pilot-study phase.

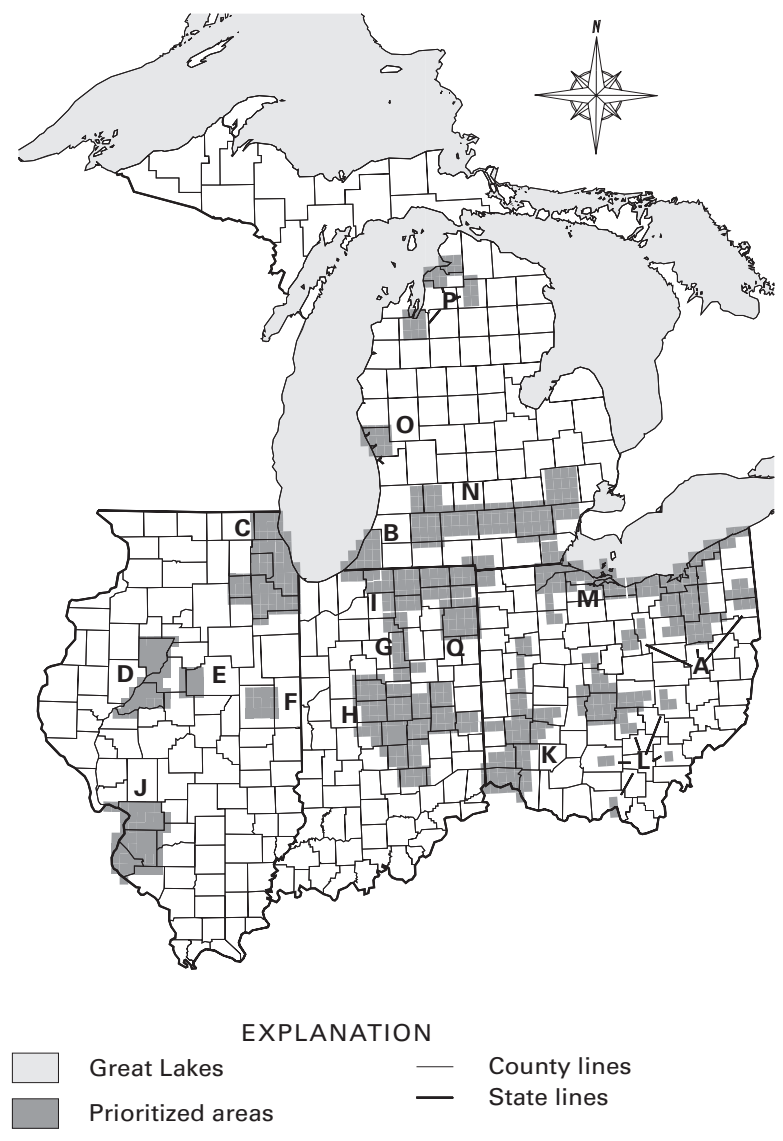

Figure 21. Proposed mapping areas for the intensive mapping phase of the Central Great Lakes Geologic Mapping Program.

The budget supports 42 new staff members, who are distributed among the five surveys. This staff includes 10 surficial geologists (or full-time equivalent [FTE] staff), 15 GIS and data-base specialists, 7 illustrators/editors, 5 laboratory technicians, and $5 \mathrm{E} / \mathrm{O}$ specialists. The budget for the third year also shows full personnel expenses and includes travel to meetings and publication costs. Training of scientific and support staff is emphasized throughout the 3-year pilot effort.

Budget and personnel needs of the 14-year intensive geologic mapping phase (table 7) reflect (1) increasing of budget amounts of the pilot-study phase, when field investigations and laboratory operations are maximized, and (2) increasing the budget amounts from year 3 for publication costs and presentation of mapping results. The budget also reflects an increase of the mapping effort, mainly in the addition of 37 FTE additional scientific and support staff. Much of the program infrastructure (such as laboratories and major equipment purchases) will be established during the pilot phase. However, additional computer mapping equipment, upgrades of hardware and software, and license and maintenance fees will be required periodically for the intensive-mapping phase. 
Table 6. Prioritized study areas of the intensive mapping phase.

\begin{tabular}{|c|c|c|c|}
\hline $\begin{array}{l}\text { Area } \\
\text { (fig. 21) }\end{array}$ & $\begin{array}{c}\text { Resource, hazards, and } \\
\text { environmental issues }\end{array}$ & $\begin{array}{l}\text { Thickness } \\
\text { of deposits }\end{array}$ & $\begin{array}{l}\text { Glacial terrane and } \\
\text { characteristic deposits }\end{array}$ \\
\hline $\begin{array}{l}\text { (A) Northeastern Ohio, } \\
\text { including Akron-Canton } \\
\text { pilot area }\end{array}$ & $\begin{array}{l}\text { Rapid suburban growth pressures } \\
\text { land and ground-water resources; } \\
\text { unconfined aquifers are vulnerable; } \\
\text { soil and water contamination problems } \\
\text { exist; extensive brownfields need } \\
\text { cleanup; shoreline erosion is severe; } \\
\text { this is the second largest seismogenic } \\
\text { zone in Ohio. }\end{array}$ & $<10-600 \mathrm{ft}$ & $\begin{array}{l}\text { Complex interlobate till-cored and } \\
\text { stratified moraines, overlapping } \\
\text { till-sheet deposits, buried } \\
\text { valley-fill deposits. }\end{array}$ \\
\hline $\begin{array}{l}\text { (B) Berrien County, } \\
\text { Michigan, and South Bend } \\
\text { Valley, Indiana (also a } \\
\text { pilot area) }\end{array}$ & $\begin{array}{l}\text { Outwash in the South Bend area } \\
\text { forms a vulnerable aquifer unit } \\
\text { that is used by the city; over } 40 \\
\text { miles of Lake Michigan shoreline } \\
\text { are subject to erosion; large areas } \\
\text { of abandoned industrial sites in } \\
\text { South Bend and Benton Harbor } \\
\text { need cleanup. }\end{array}$ & $<100-300 \mathrm{ft}$ & $\begin{array}{l}\text { Moraine belt; dominantly massive } \\
\text { fan-head-cored moraine and exposed fan. } \\
\text { Three Michigan Lobe moraine units } \\
\text { cross the region as well as outwash } \\
\text { from each moraine; coastal erosion due } \\
\text { to Holocene lake-level changes; } \\
\text { Saginaw Lobe sediments at the eastern } \\
\text { edge of the area. }\end{array}$ \\
\hline $\begin{array}{l}\text { (C) Chicago metropolitan } \\
\text { area, Illinois, including } \\
\text { Lake County pilot area }\end{array}$ & $\begin{array}{l}\text { The third largest urban area in the } \\
\text { U.S. has rapid urban and industrial } \\
\text { development with numerous } \\
\text { ground-water problems; conflicting } \\
\text { land uses and interaction of new land } \\
\text { and water use with wetlands and } \\
\text { agriculture and shoreline tracts; } \\
\text { and extensive demand for brownfield } \\
\text { mitigation and development. }\end{array}$ & $50-400 \mathrm{ft}$ & $\begin{array}{l}\text { Moraine belts and till plain; Wisconsin } \\
\text { Episode glacial deposits overlie Illinois } \\
\text { Episode and possibly older glacial } \\
\text { deposits. The Lake Chicago lake plain } \\
\text { is in the southeastern part of the area. }\end{array}$ \\
\hline $\begin{array}{l}\text { (D) Illinois River Valley, } \\
\text { Illinois (also a pilot area) }\end{array}$ & $\begin{array}{l}\text { Contamination problems in Peoria } \\
\text { require definition of aquifers and } \\
\text { their protecting fine-grained units; } \\
\text { nitrates and pesticides have been } \\
\text { detected in shallow wells in a } \\
\text { large irrigated agricultural area. }\end{array}$ & $25-200 \mathrm{ft}$ & $\begin{array}{l}\text { Till plain, river valley outwash, and } \\
\text { dune sheets; complex stratigraphy of } \\
\text { multiple glacial sequences and loess; } \\
\text { unique ground-water/surface-water } \\
\text { interconnection. }\end{array}$ \\
\hline $\begin{array}{l}\text { (E) Mahomet Valley, } \\
\text { central Illinois, including } \\
\text { Bloomington-Normal } \\
\text { pilot area }\end{array}$ & $\begin{array}{l}\text { The community relies on the } \\
\text { Mahomet aquifer and is searching } \\
\text { for more water due to an increase } \\
\text { in demand; soil contamination } \\
\text { indicates a need to document the } \\
\text { surface- to ground-water connection. }\end{array}$ & $200-400 \mathrm{ft}$ & $\begin{array}{l}\text { Moraine belt/till plain/buried valley; } \\
\text { thick sequence of Wisconsin Episode } \\
\text { glaciation (and older) glacial sediments; } \\
\text { the Mahomet aquifer also extends } \\
\text { into this area. }\end{array}$ \\
\hline $\begin{array}{l}\text { (F) Mahomet Valley, } \\
\text { east-central Illinois } \\
\text { (also a pilot area) }\end{array}$ & $\begin{array}{l}\text { The Mahomet aquifer receives } \\
\text { water from both the glacial deposits } \\
\text { and bedrock; upper aquifers are } \\
\text { contaminated from agricultural } \\
\text { applications; water usage is also } \\
\text { an issue. }\end{array}$ & $200-350 \mathrm{ft}$ & $\begin{array}{l}\text { Buried valley/moraine belt/till plain; } \\
\text { regional pre-Illinois Episode aquifer } \\
\text { is hidden beneath thick deposits from } \\
\text { multiple glaciations; shallow and } \\
\text { restricted Illinois Episode aquifers } \\
\text { overlie the Mahomet aquifer. }\end{array}$ \\
\hline $\begin{array}{l}\text { (G) Central Indiana, } \\
\text { including Marion pilot } \\
\text { area }\end{array}$ & $\begin{array}{l}\text { Problems include the origin of } \\
\text { the water-bearing unit and the } \\
\text { ability of clay till to protect } \\
\text { underlying water supplies. }\end{array}$ & $100-200 \mathrm{ft}$ & $\begin{array}{l}\text { Till plain/buried valley terrane; Indiana's } \\
\text { central till plain where it merges with } \\
\text { moraines of the Erie Lobe; clay till } \\
\text { overlies the city's well field. }\end{array}$ \\
\hline $\begin{array}{l}\text { (H) Central-southern } \\
\text { Indiana, including central } \\
\text { till plain pilot area }\end{array}$ & $\begin{array}{l}\text { Agricultural chemicals } \\
\text { contaminate the upper aquifer, } \\
\text { and the connection to the deeper } \\
\text { buried valley is poorly understood. }\end{array}$ & $100-200 \mathrm{ft}$ & $\begin{array}{l}\text { Till plain and broad buried valley terrane; } \\
\text { flat ground-moraine topography hides the } \\
\text { buried Anderson Valley, which is poorly } \\
\text { explored, contains a complex glacial/lacustrine } \\
\text { sequence, and is an important source of } \\
\text { ground water. }\end{array}$ \\
\hline
\end{tabular}


Table 6. Prioritized study areas of the intensive mapping phase-Continued.

\begin{tabular}{|c|c|c|c|}
\hline $\begin{array}{l}\text { Area } \\
\text { (fig. 21) }\end{array}$ & $\begin{array}{l}\text { Resource, hazards, and } \\
\text { environmental issues }\end{array}$ & $\begin{array}{l}\text { Thickness } \\
\text { of deposits }\end{array}$ & $\begin{array}{l}\text { Glacial terrane and } \\
\text { characteristic deposits }\end{array}$ \\
\hline $\begin{array}{l}\text { (I) North-central and } \\
\text { northeastern Indiana, } \\
\text { including Tri-State area, } \\
\text { Indiana, Michigan, and } \\
\text { Ohio, pilot area }\end{array}$ & $\begin{array}{l}\text { In this important agricultural } \\
\text { production zone, agricultural } \\
\text { chemicals may contaminate } \\
\text { the upper aquifer; significant } \\
\text { transportation corridors } \\
\text { cross the area. }\end{array}$ & $200-400 \mathrm{ft}$ & $\begin{array}{l}\text { Thick interlobate moraines that formed } \\
\text { between Erie and Saginaw Lobes; } \\
\text { terrane is difficult to map due to } \\
\text { interbedded stratigraphic units and } \\
\text { total thickness. }\end{array}$ \\
\hline $\begin{array}{l}\text { (J) Metropolitan East } \\
\text { St. Louis, Illinois }\end{array}$ & $\begin{array}{l}\text { Issues include ground-water } \\
\text { supply, contaminated soil and } \\
\text { water, brownfield restoration, } \\
\text { floods, and earthquakes; karst is } \\
\text { in the uplands. }\end{array}$ & $<25-150 \mathrm{ft}$ & $\begin{array}{l}\text { Outwash sediments and alluvium in the } \\
\text { Mississippi River valley system; } \\
\text { uplands are dissected glacial deposits } \\
\text { overlying karst. }\end{array}$ \\
\hline $\begin{array}{l}\text { (K) Cincinnati-Dayton } \\
\text { corridor, Ohio }\end{array}$ & $\begin{array}{l}\text { Suburban growth pressures land } \\
\text { and ground-water resources; issues } \\
\text { include soil and water contamination, } \\
\text { brownfield development, and confined } \\
\text { and unconfined aquifers, including a } \\
\text { sole source aquifer. }\end{array}$ & $<10-400 \mathrm{ft}$ & $\begin{array}{l}\text { Miami valley outwash complex and } \\
\text { valley-fill deposits; interlobate complex } \\
\text { of thick moraines with overlapping } \\
\text { Miami and Scioto Lobe till sheets. }\end{array}$ \\
\hline $\begin{array}{l}\text { (L) Columbus Metropolitan } \\
\text { Area (also includes areas in } \\
\text { south-central Ohio) }\end{array}$ & $\begin{array}{l}\text { This area has the fastest suburban } \\
\text { growth in Ohio; issues include } \\
\text { farmland preservation and ground- } \\
\text { water availability. }\end{array}$ & $<10-400 \mathrm{ft}$ & $\begin{array}{l}\text { Till plain; multiple till sheets, buried } \\
\text { valley-fill deposits; karst. }\end{array}$ \\
\hline $\begin{array}{l}\text { (M) Northwestern Ohio, } \\
\text { includes southern Lake } \\
\text { Erie pilot area }\end{array}$ & $\begin{array}{l}\text { Issues include suburban growth } \\
\text { pressure on land and ground-water } \\
\text { resources, particularly along coast; } \\
\text { soil and water contamination; } \\
\text { sediment loading problems; brownfield } \\
\text { development; and shoreline erosion. } \\
\text { Characterization of wetlands, loss } \\
\text { of fish habitats, and introduction of } \\
\text { exotic species are also problems. }\end{array}$ & $<10-250 \mathrm{ft}$ & $\begin{array}{l}\text { Ancient Lake Erie lacustrine deposits, } \\
\text { beach/dune/lacustrine suite; multiple } \\
\text { till sheets and buried valley-fill deposits; } \\
\text { bedrock knob terrane. }\end{array}$ \\
\hline $\begin{array}{l}\text { (N) South-central } \\
\text { Michigan corridor }\end{array}$ & $\begin{array}{l}\text { Issues include rapid urban } \\
\text { development; transportation } \\
\text { corridors; ground-water contamination } \\
\text { problems, including agricultural } \\
\text { contamination in the western } \\
\text { portion; and brownfields. }\end{array}$ & $<10-400 \mathrm{ft}$ & $\begin{array}{l}\text { Outwash fans and thin fine-grained } \\
\text { tills. }\end{array}$ \\
\hline $\begin{array}{l}\text { (O) Muskegon, Michigan, } \\
\text { area }\end{array}$ & $\begin{array}{l}\text { Issues include Superfund and } \\
\text { many State cleanup sites, } \\
\text { vulnerable aquifers, brownfields, } \\
\text { and shoreline erosion. }\end{array}$ & $100-300 \mathrm{ft}$ & $\begin{array}{l}\text { Outwash and lacustrine sediments; } \\
\text { dunes along Lake Michigan. }\end{array}$ \\
\hline $\begin{array}{l}\text { (P) Traverse City and } \\
\text { Petoskey, Michigan, area }\end{array}$ & $\begin{array}{l}\text { This area has the highest } \\
\text { population growth in northern } \\
\text { Michigan. Issues include } \\
\text { vulnerable aquifers, particularly } \\
\text { from agricultural chemicals } \\
\text { in fruit-growing areas. }\end{array}$ & $<50-1200 \mathrm{ft}$ & Outwash fans and thin till sheets. \\
\hline $\begin{array}{l}\text { (Q) Allen County, Indiana } \\
\text { (also a pilot area) }\end{array}$ & $\begin{array}{l}\text { Ground water is the principal } \\
\text { source of water for over half of } \\
\text { the county residents; suburban } \\
\text { encroachment on limestone } \\
\text { quarries has led to zoning } \\
\text { problems. }\end{array}$ & $30-300 \mathrm{ft}$ & $\begin{array}{l}\text { Vast lake plain with meltwater drainage } \\
\text { ways; several moraines; three known } \\
\text { late Wisconsin Episode glacial } \\
\text { sequences. }\end{array}$ \\
\hline
\end{tabular}




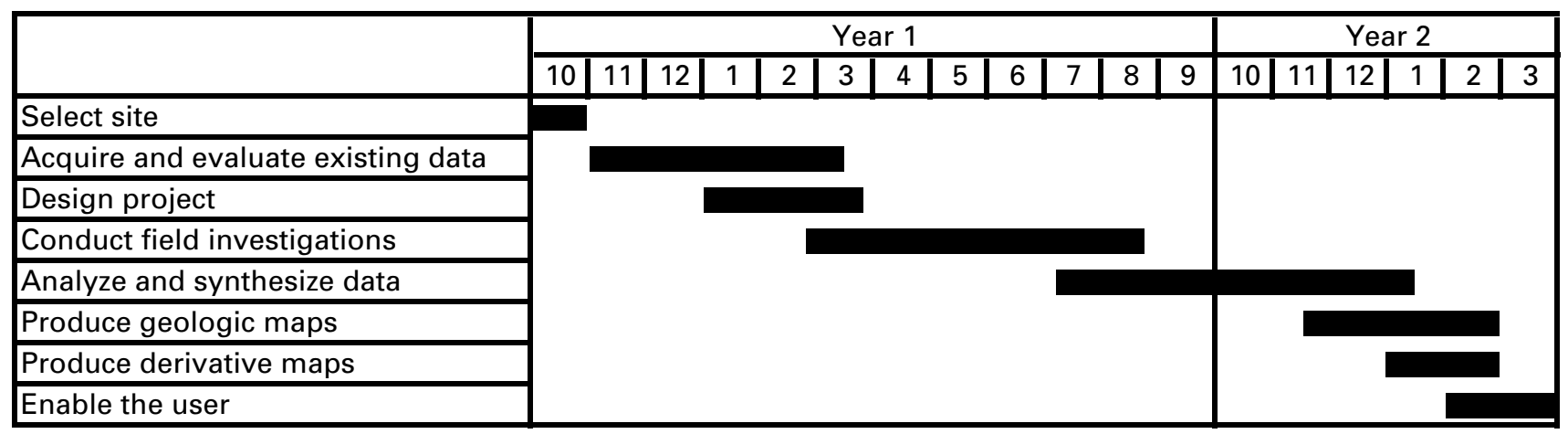

Figure 22. Time line for the 1.5-year quadrangle mapping cycle in the 14-year intensive mapping phase. Fiscal years run from October through September; the months are shown by numbers under each year.

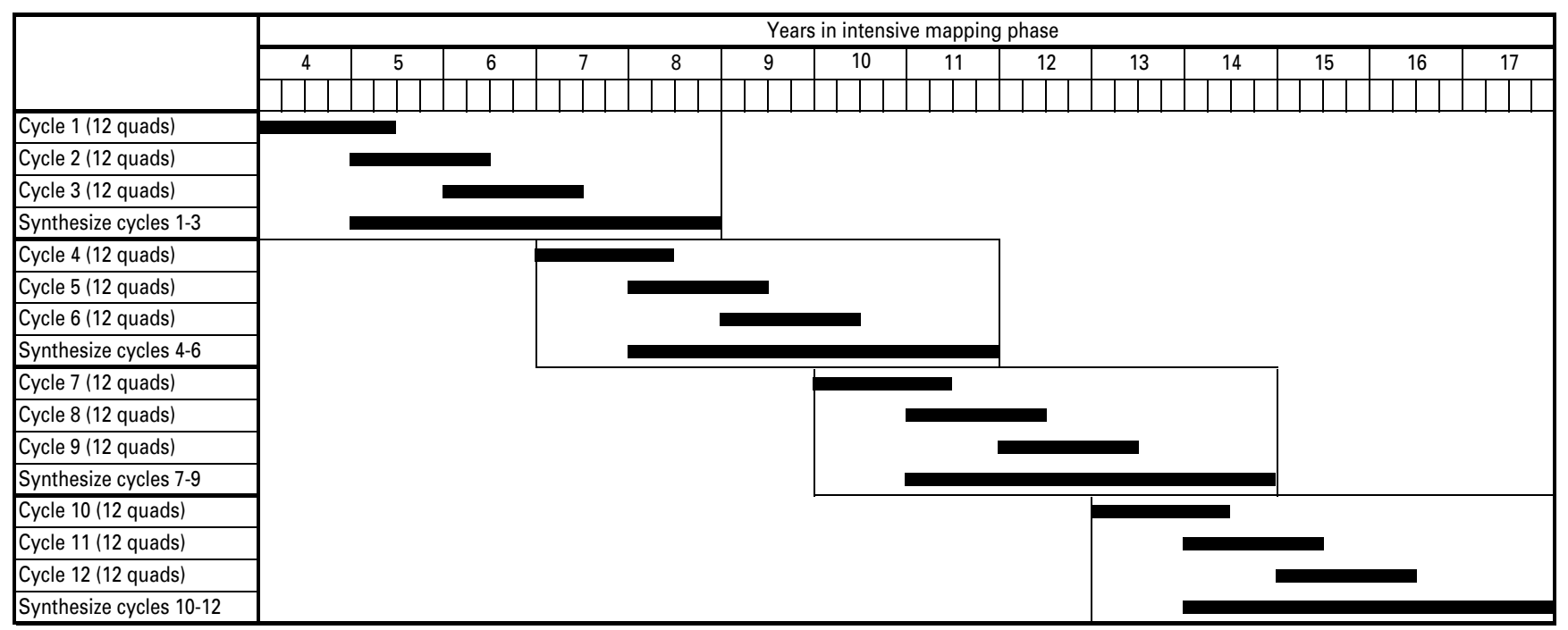

Figure 23. Time line for the 14-year intensive geologic mapping phase. Synthesize cycles include regional mapping.

By year 4 of the fully implemented program, the total proposed FTE staff will be balanced between 79 new staff positions and 20 positions on present staffs of the five surveys. At full implementation, the program balances geologists and support staff in each survey team at a ratio of 2:3. The five surveys must conduct a talent search within their own ranks to identify researchers who could contribute to the mapping program. Field geologists in the program must receive training in modern glacial environments as part of their duties.

\section{OUTCOMES OF THE PROGRAM}

\section{GEOLOGIC INFORMATION FOR THE CENTRAL GREAT LAKES STATES}

Seven basic map products and six types of ancillary map information (table 7) will be generated by the Coalition mapping program and provided to users, along with application support. Applying these products through a new geologic information delivery system, policymakers will be able to make more accurate assessments of the results of their decisions concerning sustainable development of resources, protection of people and facilities from earth hazards, and effective stewardship of the environment.

Specific outcomes of the Coalition mapping program are summarized below for nine topics. Greater detail is included in the section of this report titled "Regional Societal Issues Requiring Earth Science Information"; see articles 1-9 on yellow pages.

Competition for the land.-In each project map area, Coalition staff and collaborating partner groups will produce a folio of maps that assess the sustainable capabilities of resources and the limiting effects of hazards and environmental changes. These teams will assess the outcomes of resource, hazard, and environmental decisions based on the new, comprehensive data and analyses.

Water resources.-Each Coalition team, in partnership with water-resources experts, will quantify water use from surficial aquifers and trends in use and water quality. Each team will use new subsurface analyses, including ground- 
Table 7. Map products required for user applications.

[GW, ground water; SW, surface water]

\begin{tabular}{|c|c|c|c|c|c|c|c|c|c|c|c|c|c|c|c|c|c|}
\hline Map Products & $\begin{array}{l}\frac{\lambda}{0} \\
\frac{0}{2} \\
\frac{1}{1} \\
\frac{1}{0} \\
\frac{ \pm}{\pi} \\
3 \\
\frac{1}{0} \\
\frac{1}{0} \\
0 \\
0\end{array}$ & 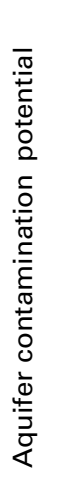 & 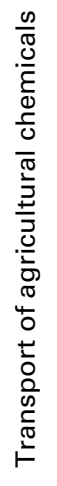 & $\begin{array}{l}0 \\
0 \\
0 \\
\frac{1}{\pi} \\
0 \\
0 \\
\frac{0}{0} \\
\frac{0}{0} \\
\frac{1}{0} \\
\frac{1}{2} \\
\frac{1}{0} \\
\stackrel{2}{2} \\
\frac{1}{4}\end{array}$ & 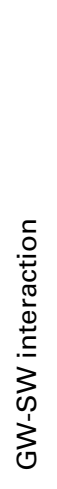 & 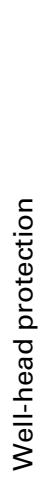 & 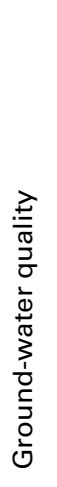 & 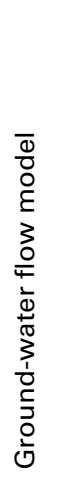 & 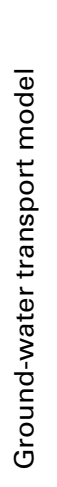 & 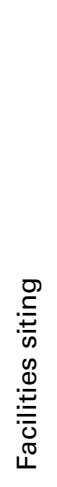 & 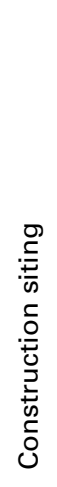 & 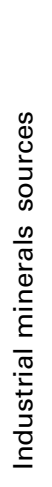 & 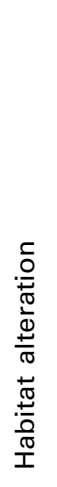 & $\begin{array}{l}\frac{0}{0} \\
\frac{0}{0} \\
\mathbb{N} \\
\frac{0}{5} \\
0 \\
0 \\
\frac{0}{4}\end{array}$ & 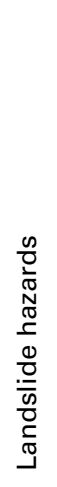 & 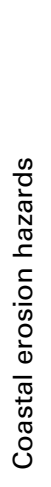 & 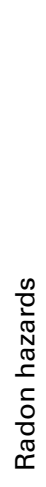 \\
\hline \multicolumn{18}{|l|}{ Basic Map Products: } \\
\hline Surface geologic materials & $\mathrm{O}$ & O & O & 0 & 0 & O & $\mathrm{O}$ & $\mathrm{O}$ & & O & O & 0 & $\mathrm{O}$ & 0 & $\mathrm{O}$ & $\mathrm{O}$ & $\mathrm{O}$ \\
\hline Subcrops and isopachs & 0 & O & 0 & $\mathrm{O}$ & $\mathrm{O}$ & $\mathrm{O}$ & $\mathrm{O}$ & 0 & 0 & 0 & $\mathrm{O}$ & 0 & & & 0 & 0 & $\mathrm{O}$ \\
\hline 3-D geologic maps & 0 & 0 & 0 & 0 & 0 & $\mathrm{O}$ & 0 & 0 & 0 & 0 & 0 & 0 & & $\mathrm{O}$ & 0 & 0 & 0 \\
\hline Bedrock topography & 0 & $\mathrm{O}$ & $\mathrm{O}$ & $\mathrm{O}$ & $\mathrm{O}$ & $\mathrm{O}$ & & 0 & 0 & $\mathrm{O}$ & 0 & $\mathrm{O}$ & $\mathrm{O}$ & & & $\mathrm{O}$ & \\
\hline Geochemistry of surficial materials & $\mathrm{O}$ & 0 & 0 & & & & O & & 0 & $\mathrm{O}$ & $\mathrm{O}$ & $\mathrm{O}$ & $\mathrm{O}$ & & & & 0 \\
\hline Hydrogeologic characterization & 0 & 0 & 0 & 0 & 0 & 0 & 0 & 0 & 0 & O & $\mathrm{O}$ & & $\mathrm{O}$ & & $\mathrm{O}$ & $\mathrm{O}$ & \\
\hline Ground-water table & $\mathrm{O}$ & 0 & 0 & 0 & 0 & $\mathrm{O}$ & $\mathrm{O}$ & 0 & $\mathrm{O}$ & 0 & 0 & $\mathrm{O}$ & 0 & & $\mathrm{O}$ & $\mathrm{O}$ & \\
\hline \multicolumn{18}{|l|}{$\begin{array}{l}\text { Ancillary Map Information from } \\
\text { Secondary Sources: }\end{array}$} \\
\hline Topography, digital orthophoto maps & $\mathrm{O}$ & $\mathrm{O}$ & $\mathrm{O}$ & $\mathbf{O}$ & $\mathbf{O}$ & $\mathrm{O}$ & $\mathrm{O}$ & $\mathrm{O}$ & $\mathrm{O}$ & O & $\mathbf{O}$ & $\mathrm{O}$ & $\mathrm{O}$ & O & $\mathbf{O}$ & $\mathbf{O}$ & $\mathrm{O}$ \\
\hline Soils & & $\mathrm{O}$ & $\mathrm{O}$ & 0 & 0 & $\mathrm{O}$ & $\mathrm{O}$ & $\mathrm{O}$ & $\mathrm{O}$ & $\mathrm{O}$ & 0 & & 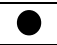 & 0 & $\mathrm{O}$ & & $\mathrm{O}$ \\
\hline Drainage basin & $\mathrm{O}$ & $\mathrm{O}$ & $\mathrm{O}$ & $\mathrm{O}$ & $\mathrm{O}$ & & $\mathrm{O}$ & $\mathrm{O}$ & & $\mathrm{O}$ & & & & 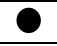 & & & \\
\hline Point sources of contamination & O & O & 0 & 0 & $\mathrm{O}$ & O & 0 & & O & O & 0 & & $\mathrm{O}$ & $\mathrm{O}$ & & & \\
\hline Land use (current and historical) & $\mathrm{O}$ & 0 & & 0 & $\mathrm{O}$ & 0 & $\mathrm{O}$ & $\mathrm{O}$ & $\mathrm{O}$ & $\mathrm{O}$ & $\mathrm{O}$ & $\mathrm{O}$ & $\mathrm{O}$ & $\mathrm{O}$ & $\mathrm{O}$ & $\mathrm{O}$ & \\
\hline Infrastructure and demography & 0 & O & & $\mathrm{O}$ & $\mathrm{O}$ & $\mathrm{O}$ & 0 & $\mathrm{O}$ & 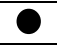 & 0 & $\mathrm{O}$ & $\mathrm{O}$ & 0 & 0 & 0 & 0 & \\
\hline
\end{tabular}

water head measurements to differentiate individual surficial aquifers and define newly discovered aquifers in the regional aquifer system around each project area.

Construction materials.-The Coalition staff, in partnership with departments of transportation and industry, will develop techniques to accurately assess the volume and quality of construction sand and gravel aggregate materials, as well as land-use decisions that preempt sustainable aggregate extraction and use. The Coalition will assess regional outcomes of aggregate markets and competing land uses.

Coastal erosion.-For Coalition projects in Great Lakes coastal areas, each project team, in partnership with coastal-process experts, will produce maps showing onshore and offshore surficial materials and top of bedrock and will analyze historical shoreline recession or advance. These teams will describe the effects of surficial materials, ground water, and coastal and slope processes on the evolving coastlines. The Coalition will institute plans for rapid response teams for large erosion and flood events.

Floods.-Each Coalition team will define the active geomorphic flood plain and floodable surfaces along major rivers and tributary streams in the study areas. In partnership with surface-water experts, the teams will assess (1) historical flood extents and examples of flood erosion and sedimentation, and (2) trends in flood frequency, flood energy, land use, and structures in the flood plain. The Coalition will institute plans for rapid response teams for large flood events.

Earthquakes.-Each Coalition team, in partnership with seismic experts, will determine the extent and geotechnical characteristics of earth materials that are susceptible to seismically induced liquefaction or landslides. These teams will assess seismicity risks to geologic units or land uses in areas of historical or prehistoric earthquakes.

Contamination of land and water-In each project area, Coalition staff will establish the natural background geochemical characteristics of surficial geologic units. In partnership with water-resources experts, project teams will compare these with geochemical trends of ground water, especially in areas containing known pollution sites. Sensitivity of surficial aquifers and other lands to contamination by historical or existing land use will be assessed.

Ecosystem change.-In each study area, Coalition teams, in partnership with biologists and hydrologists, will include analyses of the sensitive relationship between 
ground-water and surface-water interactions and the potential impacts of various land uses surrounding ecologically sensitive areas to provide decisionmakers with a better understanding of the physical ecosystem.

Education as part of the program.-In training programs and public workshops, each Coalition team will educate partner groups in the use of software and analytic techniques. Program geologic and support staff will be trained in new technologies and in cooperating with user groups.

\section{ENHANCING THE PUBLIC SERVICE MISSION OF THE GEOLOGICAL SURVEYS}

A novel feature of this program is its emphasis on communication, cooperation with, and support of public policymakers in their critical decisionmaking process. The cooperation of public officials will be sought from the early stages of the mapping program in each pilot study area and in each intensive study area. Public input will be a deciding factor in selecting sites, studies, and map products. The Liaison Committee will implement the process. All professional members of the project also will be expected to interact with these policymaking officials throughout the course of the project. Education/outreach professionals in each of the five geological surveys will assist them in developing avenues of communication.

\section{SCIENCE-BASED DECISION-SUPPORT SYSTEMS}

A set of powerful computer-assisted decision-support tools will be created by combining three-dimensional geologic map information with economic, demographic, and other societal data, in a system that provides compelling graphic representations of the consequences of "what-if" scenarios involving public-policy decisions. For example, by combining a map showing the depth to aquifers with maps showing composition of surface soils and agricultural land use, an aquifer vulnerability map can be created that will allow evaluation of potential for contamination of ground water from pesticides and fertilizers. Such a map permits rapid, informed decisions on whether agricultural chemical regulations are advisable and prevents overregulation in situations where they are not needed.

Other potential products can be used to address issues such as the effect of mining aggregate on ground-water quantity and quality, the landslide potential of alternative construction sites for buildings or transportation systems, the potential for contaminating ground water by permitting septic tanks in new subdivisions, the potential effects of various kinds of development on nearby wildlife habitats, and many more.

This decision-support system will be provided to public- and private-sector users with educational support in their operation and potential uses by the education/outreach coordinators and other staff. The outcome of such a system will be better, faster decisions on policy issues involving zoning, permitting, and resource utilization.

\section{EDUCATION OF SURFICIAL GEOLOGISTS RESULTS IN INCREASED INFORMATION AND ITS APPLICATION, NATIONWIDE}

Surficial geologic mapping is an under-populated professional field at present, which has made it difficult for the State Geological Surveys to hire adequate staff to carry out the necessary mapping to meet their mandates. By working directly with university faculty, employing student trainees to help with mapping, and providing a ready job market for graduates, this program will increase the number of surficial geologists available for this and other surficial geologic mapping projects. Furthermore, the unique communications/outreach model developed by this program will result in a generation of geologists who appreciate the societal application of their information products and are trained and experienced in communication and cooperation with policymakers in the public and private sectors. Thus, the available information concerning surficial geology and its societal impacts will be increased, nationwide, by this program.

\section{PUBLIC AWARENESS OF EARTH SCIENCE ISSUES IN PUBLIC POLICY}

Through its unique education/outreach initiative, this geologic mapping program will result in improved public awareness of, and appreciation for, the importance of making public-policy decisions in the light of all appropriate earth-science information. The geologic information delivery system will provide dramatic, graphic scenarios illustrating the consequences of informed versus uninformed decisions, thus improving the public understanding of earth science and the use of electronic systems in logical decisionmaking, which is emerging as a major new tool in public policy worldwide.

\section{IMPROVING COMMUNICATION BETWEEN EARTH SCIENTISTS AND PUBLIC POLICYMAKERS}

The education/outreach initiative of this program, assisted by a fully functioning geologic information delivery system, will result in new models for communication between policymakers and earth scientists, allowing each a new appreciation for the other. This appreciation will result in more informed decisions because the earth scientists will learn to present relevant information in understandable language. Using the geologic information delivery system, they will be able to predict in a dramatic and usable way, the consequences of various policy options. 


\section{EXTENSION OF COOPERATIVE SURFICIAL GEOLOGIC MAPPING PROGRAMS TO OTHER REGIONS OF THE COUNTRY AND THE WORLD}

By creating a geologic information delivery system, a pool of trained surficial geologists, an education/outreach model, and a model for cooperative science and society programs, this geologic mapping program will advance the development of effective and societally relevant surficial geologic mapping nationwide, perhaps even worldwide. Other groups of States or countries will be welcome to share all the tools and concepts developed in this program so that they can reproduce this effort, at a considerably reduced cost, to meet their own mapping needs. All of the main features of this program are eminently transferable, and thus provide benefits far beyond the boundaries of the Central Great Lakes States.

\section{REFERENCES}

Algermissen, S.T., and Hopper, M.G., 1985, Maps of hypothetical intensities for the region, in Hopper, M.G., ed., Estimation of earthquake effects associated with large earthquakes in the New Madrid seismic zone: U.S. Geological Survey Open-File Report 85-457, p. 42-51.

American Society for Testing and Materials (ASTM), 1995, Standard practice for description and identification of soils (visual-manual procedure), Designation D2488-95: American Soil and Rock; Dimension Stone; Geosynthetics: Philadelphia, Pa., p. 3-332.

Berg, R.C., and Collinson, C., 1976, Bluff erosion, recession rates, and volumetric losses on the Lake Michigan shore in Illinois: Illinois State Geological Survey Environmental Geology Notes 76, 33 p.

Berg, R.C., Kempton, J.P., and Stecyk, A.N., 1984, Geology for planning in Boone and Winnebago Counties: Illinois State Geological Survey Circular 531, 69 p.

Bernknopf, R.L., Brookshire, D.S., Soller, D.R., McKee, M.J., Sutter, J.F., Matti, J.C., and Campbell, R.H., 1993, Societal value of geologic maps: U.S. Geological Survey Circular $1111,53 \mathrm{p}$.

Bhagwat, S.B., and Berg, R.C., 1991, Benefits and costs of geologic mapping programs in Illinois; Case study of Boone and Winnebago Counties and its statewide applicability: Illinois State Geological Survey Circular 549, 40 p.

Bleuer, N.K., Melhorn, W.N., Steen, W.J., and Bruns, T.M., 1991, Aquifer systems of the buried Marion-Mahomet trunk valley (Lafayette Bedrock Valley System) of Indiana, in Melhorn, W.N., and Kempton, J.P., eds. Geology and hydrogeology of the Teays-Mahomet Bedrock Valley Systems: Geological Society of America Special Paper 258, p. 79-89.

Central Great Lakes Geologic Mapping Coalition, 1999, Sustainable growth in America's heartland-3-D geologic maps as the foundation: U.S. Geological Survey Circular 1190, $17 \mathrm{p}$.

Central United States Earthquake Consortium, 1995, Earthquake hazards map, showing areas of relative potential for shaking and/or liquefaction: Illinois State Geological Survey map, scale 1:2,000,000.
Chrzastowski, M.J., Killey, M.M., Bauer, R.A., DuMontelle, P.B., Erdmann, A.L., Herzog, B.L., Masters, J.M., and Smith, L.R., 1994, The Great Flood of 1993-Geologic perspectives on flooding along the Mississippi River and its tributaries in Illinois: Illinois State Geological Survey Special Report 2, 45 p.

Curry, B.B., Berg, R.C., and Vaiden, R.A., 1997, Geologic mapping for environmental planning, McHenry County, Illinois: Illinois State Geological Survey Circular 559, 79 p.

Duval, J.S., 1987, Aerial radiometric color contour maps and composite color map of regional surface concentrations of uranium, potassium, and thorium in Ohio: U.S. Geological Survey Geophysical Investigations Map GP-966, 4 maps, scale 1:1,000,000.

Eastman, R., Nelson, B., and Shields, G., 1978, Isodemographic map of North America, 1975-1976: Kingston, Ontario, Canada, Queens University, Department of Geography.

Federal Emergency Management Agency, 1995, NEHRP [National Earthquake Hazards Reduction Program] recommended provisions for seismic regulations for new buildings (1994 ed.): Washington, D.C., Part 1, Provisions (FEMA-222A), 290 p. ; Part 2, Commentary (FEMA-223A), 335 p. (Prepared by the Building Seismic Safety Council for FEMA.)

Fullerton, D.S., Cowan, W.R., Sevon, W.D., Goldthwait, R.P., Farrand, W.R., Muller, E.H., Behling, R.E., and Stravers, J.A., comps., 1991, Quaternary geologic map of the Lake Erie $4^{\circ} \times 6^{\circ}$ quadrangle, United States and Canada: U.S. Geological Survey Miscellaneous Investigations Series Map I-1420 (NK-17), 8-p. text, 1 sheet, scale 1:1,000,000.

Goebel, J.E., Mickelson, D.M., Farrand, W.R., Clayton, Lee, Knox, J.C., Cachow, Adam, Hobbs, H.C., and Walton, M.S., Jr., comps., 1983, Quaternary geologic map of the Minneapolis $4^{\circ} \mathrm{X} 6^{\circ}$ quadrangle, United States: U.S. Geological Survey Miscellaneous Investigations Series Map I-1420 (NL-15), 1 sheet, scale 1:1,000,000.

Grannemann, N.G., and Twenter, F.R., 1985, Geohydrology and ground-water flow at Verona well field, Battle Creek, Michigan: U.S. Geological Survey Water-Resources Investigations Report 85-4056.

Gray, H.H., Bleuer, N.K., Lineback, J.A., Swadley, WC, Richmond, G.M., Miller, R.A., Goldthwait, R.P., and Ward, R.A., comps., 1991, Quaternary geologic map of the Louisville $4^{\circ} \times 6^{\circ}$ quadrangle, United States: U.S. Geological Survey Miscellaneous Investigations Series Map I-1420 (NJ-16), scale 1:1,000,000.

Holmes, A., 1965, Principles of physical geology: New York, Ronald Press, 901 p.

Hughes, R.E., and Bradbury, J.C., 1989, Proceedings of the 23rd forum on the geology of industrial minerals: Illinois State Geological Survey Illinois Minerals 102, 105 p.

Illinois Department of Natural Resources, 1996, Rock River area assessment, v. 1, Natural Resources: Earth Resources, p. 20-27.

Illinois Environmental Protection Agency, 1998, Draft Illinois Source Water Assessment and Protection Program application, submitted to the United States Environmental Protection Agency Region V pursuant to Section 1453 of the Safe Drinking Water Act: Illinois Environmental Protection Agency, 146 p. 
International Consultants, Inc., 1998, Ground Water Rule, vulnerability assessment study, final report, revision 2 (final): Prepared under U. S. Environmental Protection Agency contract no. 68-C6-0039, task order 4, 29 p.

Kempton, J.P., 1981, Three-dimensional geologic mapping for environmental studies in Illinois: Illinois State Geological Survey Environmental Geology Notes 100, 43 p.

Killey, M.M., and DuMontelle, P.B., 1984, Earthquakes in the Illinois area: Illinois State Geological Survey and Illinois Emergency Services and Disaster Agency pamphlet, 4 p.

Kincare, K.A., 1989, Geostatistical decision making process in plume modeling: Proceedings Superfund 1989 Conference, Hazardous Materials Control Research Institute, Silver Springs, Md., p. 181-189.

Koteff, Carl, and Pessl, Fred, Jr., 1981, Systematic ice retreat in New England: U.S. Geological Survey Professional Paper $1179,20 \mathrm{p}$.

Lane, E., and Rupert, F., 1996, Earth systems-The foundation of Florida's ecosystems: Florida Geological Survey poster.

Leverett, Frank, and Taylor, F.B., 1915, The Pleistocene of Indiana and Michigan and the history of the Great Lakes: U.S. Geological Survey Monograph 53, 529 p.

Lineback, J.A., Bleuer, N.K., Mickelson, D.M., Farrand, W.R., and Goldthwait, R.P., comps., 1983, Quaternary geologic map of the Chicago $4^{\circ} \times 6^{\circ}$ quadrangle, United States: U.S. Geological Survey Miscellaneous Investigations Series Map I-1420 (NK-16), 1 sheet, scale 1:1,000,000.

McGrain, Preston, 1979, An economic evaluation of the Kentucky geologic mapping program: Lexington, Ky., Kentucky Geological Survey, series XI, 12 p.

Melhorn, W.N., and Kempton, J.P., eds., 1991, Geology and hydrogeology of the Teays-Mahomet bedrock valley systems: Geological Society of America Special Paper 258, 128 p.

Munsell Color Company, 1975, Munsell soil color charts: Baltimore, Md., 15 p.

Munson, P.J., Obermeier, S.F., Munson, C.A., and Hajic, E.R., 1997, Liquefaction evidence for Holocene and latest Pleistocene seismicity in the southern halves of Indiana and Illinois: A preliminary overview: Seismology Research Letters, v. 68, no. 4, p. 521-536.

National Groundwater Association, 1997, Wells in place (not annual construction) July 8, 1997.

National Science Foundation, 1996, National patterns of R\&D resources, 1996: National Science Foundation Report NSF 96-333, table C-17.

Pavey, R.R., 1987, Glacial materials stack-unit map [Super-conducting Super Collider Project]: Ohio Division of Geological Survey Open-File Map 263, scale 1:62,500.

Soller, D.R., 1992, Text and references to accompany "Map showing the thickness and character of Quaternary sediments in the glaciated United States east of the Rocky Mountains": U.S. Geological Survey Bulletin 1921, 54 p.

Soller, D.R., 1998, Map showing the thickness and character of Quaternary sediments in the glaciated United States east of the Rocky Mountains: Northern Great Lakes States and Central Mississippi Valley States, the Great Lakes, and southern Ontario (80 $31^{\circ}$ to $93^{\circ}$ West Longitude): U.S. Geological Survey Miscellaneous Investigations Series Map I-1970-B, scale 1:1,000,000.
Soller, D.R., Price, S.D., Kempton, J.P., and Berg, R.C., 1999 , Three-dimensional geologic maps of Quaternary sediments in east-central Illinois: U.S. Geological Survey Geologic Investigations Series Map I-2669, 3 sheets, scale 1:500,000. (Previews are available on the World Wide Web at http:// ncgmp.usgs.gov/ecill/.)

Stone, B.D., Stanford, S.D., and Witte, R.W., in press, Surficial geologic map of northern New Jersey: U.S. Geological Survey Miscellaneous Investigations Series Map I-2540-C, 3 sheets and pamphlet, scale 1:100,000.

Su, W.J., and Bauer, R.A., 1998, Measurement of seismic wave velocity in southern Illinois for microzonation mapping and study of liquefaction potential: Illinois State Geological Survey proposal to the National Earthquake Hazards Reduction Program (NEHRP), 23 p.

U.S. Bureau of Mines, 1933-71, Minerals yearbook: Washington, D.C.

U.S. Department of Agriculture, 1982, 1987, 1992, Natural resources inventory.

U.S. Department of Agriculture, 1992, Census of agriculture, 1982, 1987, 1992.

U.S. Department of Commerce, Bureau of the Census, 1997, Population estimates program.

U.S. Department of Commerce, Bureau of the Census, 1998, Annual survey of manufacturers, geographic area statistics, April 1998, 146 p.

U.S. Environmental Protection Agency, 1999, Envirofacts warehouse: Available on the World Wide Web at www.epa.gov/enviro/.

U.S. Geological Survey, 1999, Minerals information: Available on the World Wide Web at http://minerals.er.usgs.gov/minerals/pubs/commodity.

\section{GLOSSARY}

Terms italicized within a definition are themselves defined elsewhere in the Glossary. If a comment applies to the use of a term in the Central Great Lakes region, it is given at the end of the definition after a long dash (-).

Aquifer-A body of earth materials that contains sufficient saturated permeable material to conduct ground water and to yield significant quantities of water to wells and springs-includes (1) confined aquifers, in which flow of ground water in subsurface units is restricted by low hydraulic conductivity of overlying units, and (2) unconfined aquifers, in which ground water extends upward to the water table that marks the water pressure (head) of the ground water.

Aquifer system-A heterogeneous body of intercalated permeable and less permeable material that acts as a water-yielding hydraulic unit of regional extentin surficial aquifers, a body of earth materials that includes an aquifer and lateral and overlying connected materials of the unsaturated (vadose) zone that contributes water to the aquifer within the surface- and ground-water drainage basin. 
Bedrock geology - The study of the characteristics, origin, creative processes, age, and history of solid rock units and structures that underlie surficial materials. See surficial geology.

Colluvium-A general term applied to any loose, heterogeneous, and incoherent mass of surficial materials and (or) rock fragments deposited by rainwash, sheetwash, or slow continuous downslope creep, usually collecting at the base of single slopes or hillsides.

Depositional sequence stratigraphy-The study of vertical relationships between geologic units formed in different sedimentary environments (lithofacies) and the recognition of the chronology of events they represent and the patterns they produce in the subsurface.

Drift-A general term applied to all disaggregated rock material (clay, silt, sand, gravel) transported by a glacier and deposited directly by or from the ice, or by running water emanating from a glacier; generally applied to Pleistocene glacial deposits in areas that no longer contain glaciers.

Earth-surface processes-Mechanical and chemical means that erode, transport, and deposit nonlithified earth materials at the Earth's surface, commonly water, ice, wind, or gravity. Syn: Surficial processes.

Geologic information delivery system-The coordination of data bases containing field data, laboratory results, geologic maps, and derivative map products in readily accessible formats, from paper maps, digital map coverages, three-dimensional models, to CD-ROM (compact disc, read-only memory) or Internet distribution, to be designed around the needs of the user community.

Glacial geology-A subdiscipline of geology that studies glacial processes and resulting sediments and landscapes.

Glacial terrane characterization-Description of glacial deposits by their distinctive landscapes that contain genetically related groups of landforms and their associated vertical depositional sequences.

Holocene-The geologic epoch extending from about 10,000 years ago to the present; also referred to as the "postglacial" or the "Recent" time interval.

Hydraulic conductivity-The rate at which water flows through earth materials.

Hydrogeology-The study of the relationship between ground water and the geologic materials through which it flows; hydrogeologists define subsurface geologic units and measure the quantity and quality of the contained ground water.

Lithofacies-A lateral, mappable subdivision of a designated stratigraphic unit, distinguished from adjacent subdivisions on the basis of lithologic characteristics related to sedimentary environment.
Lithology - The study of the physical character of a rock or surficial material, described in hand specimen or in outcrop, on the basis of such characteristics as color, mineralogic composition, grain size, and structure; the physical characteristics of a rock or surficial material.

Loess-A widespread, homogeneous, commonly nonstratified, porous, friable, fine-grained blanket deposit consisting primarily of silt; loess is generally windblown dust carried from alluvial valleys and outwash plains.

Moraine-A landform composed of glacial deposits built by the direct action of glacier ice and having initial positive constructional topography that is independent of bedrock-controlled topographyground moraine is typically a flat landform underlain by till; end moraine is typically an elongate low ridge or series of hummocky ridges composed of glacial deposits, built by the direct action of glacier ice or meltwater streams along the margin of a glacier.

Nonlithified materials_Loosely aggregated, soft, or liquid mineral or organic substances, such as loose gravel, sand, silt, and plastic clay, commonly unconsolidated materials, that have not been cemented to form solid rock. Syn.: surficial materials.

Outcrop-That part of a geologic formation or structure that appears at the surface of the Earth.

Outwash-Sorted and stratified sediments deposited by meltwater streams in front of glacier ice.

Paleosol-A soil that formed on the landscape in the past with distinctive morphological features resulting from a soil-forming environment that no longer exists at the site-commonly preserved in the subsurface as a buried unit.

Permeability - The capacity of earth materials to transmit any fluid.

Pleistocene-The geologic epoch extending from 1.83 million years ago to about 10,000 years ago; generally referred to as the "ice age."

Quaternary-The geologic period extending from 1.83 million years ago to the present, and including the Pleistocene and Holocene Epochs.

Residuum (residual material)_Unconsolidated material or partly weathered earth material presumed to have developed in place by weathering from the consolidated rock on which it lies.

Soil-The unconsolidated mineral or organic materials on the immediate surface of the Earth that serve as the natural medium for the growth of land plants; [engineering] all unconsolidated materials above bedrock. 
Stratigraphic units-Geologic material bodies recognized for any purpose such as description, mapping, or correlation; includes lithostratigraphic units, formal and informal "rock units"; also referred to as geologic units in this report.

Subcrop-The subsurface areal distribution of geologic units that are truncated by the unconformity at the base of overlying units-in glacial terrane, the subcrop of bedrock geologic units is truncated by the rock surface that is buried by surficial materials.

Subsurface geology-Geology and correlation of geologic units, structures, and other features beneath the land or sea-floor surface as revealed by or inferred from exploratory drilling, underground workings, and geophysical methods. Ant.: surface geology.

Surface geology-Geology and correlation of geologic units, structures and other features as seen at the Earth's surface. Ant.: subsurface geology.

Surficial aquifer-A body of surficial materials that produces ground water.

Surficial deposit-A body of nonlithified earth materials that accumulated by some natural process or agent.

Surficial geologic map-A graphic display on a topographic base that shows the surface distribution of surficial materials in that area-includes map area, description of units, explanation of symbols, agecorrelation diagram, cross sections or profiles, and explanatory text.

Surficial geology - The study of the characteristics, origin, age, and history of nonlithified earth materials, including studies of the bedrock surface, and studies of processes that actively erode, transport and deposit these materials. See bedrock geology.
Surficial materials-Nonlithified earth materials, such as loose gravel, sand, silt, and plastic clay, commonly unconsolidated materials, that overlie the solid bedrock surface-includes materials produced by chemical weathering (residuum) and surficial deposits produced by wind, water, gravity, and glaciers. (loess, sand and gravel, colluvium, and till).

Surficial processes-Syn.: Earth-surface processes.

Three-dimensional map-A graphic depiction of the surface and subsurface distribution of earth materials by means of colors, patterns, or compound mapunit symbols.

Till—Compact mixture of sand, silt, and clay matrix containing scattered gravel clasts, deposited directly by or from glacial ice without intervening sorting by water.

Unconsolidated material-[Engineering] loosely aggregated, soft, or liquid mineral or organic substance, commonly referred to as soil-consolidation is used by some engineers in reference to any process whereby loosely aggregated earth materials become firm and coherent rock; in general, consolidation refers to the gradual reduction in volume and increase in density of a soil mass in response to increased load or effective compressive stress; the related term compaction is any process, such as burial or desiccation, by which a soil mass loses pore space and becomes more dense; in this report, unconsolidated materials are referred to as "nonlithified materials." 
Generalized glacial terranes of the Central Great Lakes region based on data from Goebel and others (1983), Lineback and others (1983), Fullerton and others (1991), Gray and others (1991), Melhorn and Kempton (1991), and Soller (1998). Each terrane contains a similar series of vertically stacked deposits below the land surface (see fig. 7 and text discussion on p. 16). The thickness and characteristics of these deposits are known only at regional scale, based on analyses of water-well records and local test wells. The glacial border on the map shows the southern extent of continental glaciation.

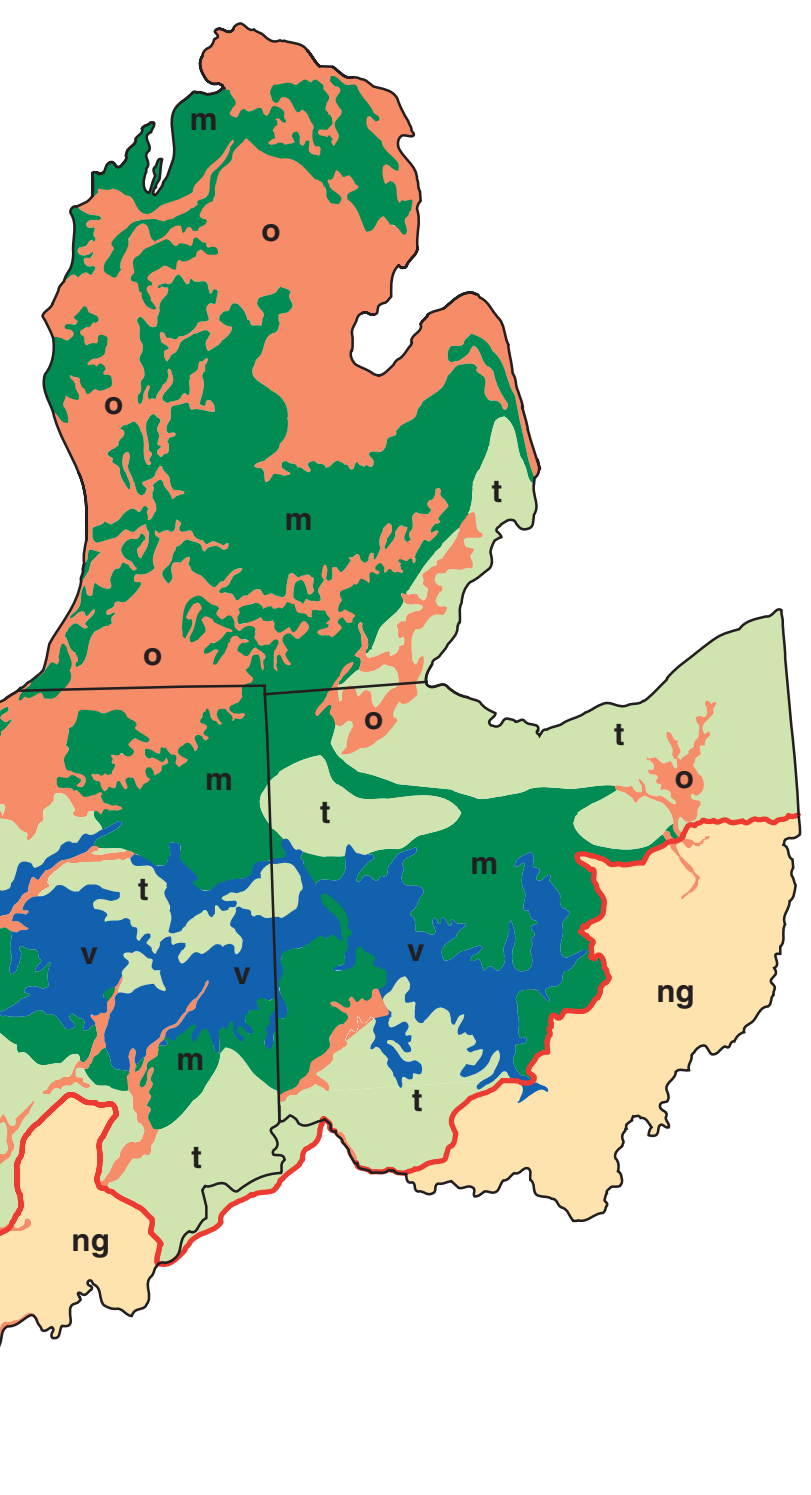

\begin{tabular}{|c|c|c|c|}
\hline $\begin{array}{l}\text { Glacial terrane } \\
\text { (map symbol) }\end{array}$ & $\begin{array}{l}\text { Thickness } \\
\text { of } \\
\text { deposits }\end{array}$ & $\begin{array}{c}\text { Characteristic deposits } \\
\text { and complexity }\end{array}$ & Geologic features \\
\hline $\begin{array}{l}\text { Moraine belts } \\
\qquad(\mathrm{m})\end{array}$ & $100-1300 \mathrm{ft}$ & $\begin{array}{l}\text { Series of surface moraines and } \\
\text { surface/subsurface glacial-stream and } \\
\text { glacial-lake deposits, locally multiple } \\
\text { subsurface glacial/interglacial deposits }\end{array}$ & $\begin{array}{l}\text { Prominent and subtle moraines, } \\
\text { containing till cores, glaciotectonic } \\
\text { structures, or stratified deposits }\end{array}$ \\
\hline $\begin{array}{l}\text { Meltwater } \\
\text { deposit } \\
\text { complexes } \\
\text { (o) }\end{array}$ & $<10->200 \mathrm{ft}$ & $\begin{array}{l}\text { Glacial-stream (outwash) deposits in } \\
\text { large valleys, and glacial-lake deltas, } \\
\text { fans, and fine-grained lake-bottom } \\
\text { deposits in sediment-dammed basins }\end{array}$ & $\begin{array}{l}\text { Glacial-stream plains in south- } \\
\text { draining valleys, glacial-lake } \\
\text { deposits at varying altitudes in } \\
\text { small and large lake basins, } \\
\text { detailed ice-retreat and drainage- } \\
\text { diversion records }\end{array}$ \\
\hline $\begin{array}{l}\text { Buried valleys } \\
\qquad \text { (v) }\end{array}$ & $<100-700 \mathrm{ft}$ & $\begin{array}{l}\text { Ancient glacial deposits, thick } \\
\text { sequences of glacial-stream sediments, } \\
\text { and some full valley-filling lake } \\
\text { sequences that represent the oldest } \\
\text { known ice sheets, capped by surface } \\
\text { till, glacial-stream, lake, or moraine } \\
\text { deposits of the last two ice sheets }\end{array}$ & $\begin{array}{l}\text { Series of ancient valley reaches } \\
\text { that were modified and produced } \\
\text { by glacial erosion and drainage } \\
\text { diversions; includes emergent } \\
\text { valley in southeastern Ohio }\end{array}$ \\
\hline $\begin{array}{l}\text { Till plains } \\
\qquad(\mathbf{t})\end{array}$ & $<10-100 \mathrm{ft}$ & $\begin{array}{l}\text { Surface deposits of till, alluvium, and lakes } \\
\text { and eolian sediments locally with surface } \\
\text { glacial-stream and lake deposits }\end{array}$ & $\begin{array}{l}\text { Flat areas underlain chiefly by one } \\
\text { or more tills and loess; includes } \\
\text { older, highly weathered and } \\
\text { dissected Illinoian till plain }\end{array}$ \\
\hline $\begin{array}{l}\text { Near-glacial and } \\
\text { periglacial } \\
\text { terranes } \\
\text { (ng) }\end{array}$ & $<10-200 \mathrm{ft}$ & $\begin{array}{l}\text { Hillslope deposits (colluvium) and valley } \\
\text { deposits of glacial streams and lakes; } \\
\text { locally capped by windblown sediments }\end{array}$ & $\begin{array}{l}\text { Steep slopes, preglacial and } \\
\text { interglacial valleys }\end{array}$ \\
\hline
\end{tabular}




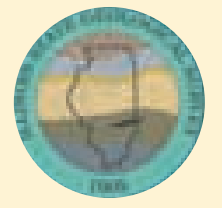

The Illinois State Geological Survey (of the Illinois Department of Natural

Resources), created in its modern form by legislative mandate in 1905, provides objective scientific information to government, business, and the public. The work is guided by two major objectives-

- To improve the quality of life for Illinois citizens by providing the scientific information and interpretations needed for developing sound environmental policies and practices.

- To strengthen the Illinois economy by promoting wise development of the State's abundant mineral resources.

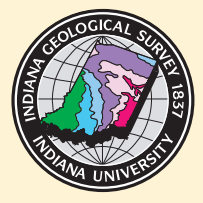

The Indiana Geological Survey, which is an institute of Indiana University, was established in 1837; it has a statutory mission-

- To provide geologic information and counsel that contribute to the wise stewardship and economic development of the energy, mineral, and ground-water resources of Indiana.

The Indiana Geological Survey works to discover and promote the development and conservation of these resources; maintains geologic data bases and sample libraries; investigates geologic hazards and environmental issues; and disseminates information through public education, maps and reports, and consultation with the public.

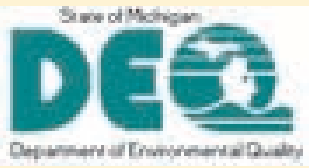

The Michigan Geological Survey Division (of the Michigan Department of Environmental Quality) is the oldest Michigan State agency; it was established in 1837, the same year that Michigan was admitted to the Union. The mission of the Michigan Geological Survey Division is-

- To encourage conservation and protect natural resource values in developing the geological resources of the State, including fossil fuels, minerals, and ground water.

- To identify, develop, and disseminate geological information for the benefit of Michigan citizens.

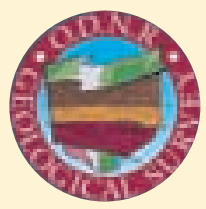

The Ohio Division of Geological Survey (of the Ohio Department of Natural Resources) is Ohio's oldest natural resources agency; it was established in 1837 to investigate the geology and mineral resources of the State of Ohio. The mission of the Ohio Division of Geological Survey is-

- To provide geologic information and services needed for responsible management of Ohio's natural resources.

The U.S. Geological Survey, established in 1879, is an earth science organization within the U.S. Department of the Interior; the USGS is recognized worldwide as scientifically credible, objective, and demonstrably relevant to society's needs.

The mission of the USGS is-

- To provide the Nation with reliable, impartial information to describe and understand the Earth. This information is used to minimize loss of life and property from natural disasters; manage water, biological, energy, and mineral resources; enhance and protect the quality of life; and contribute to wise economic and physical development.

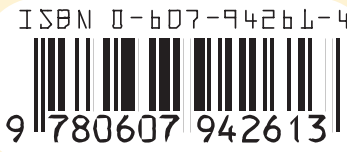

